\title{
جريمة الإبادة الجماعية
}

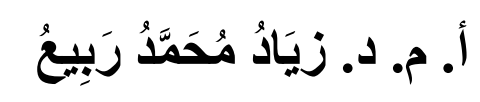

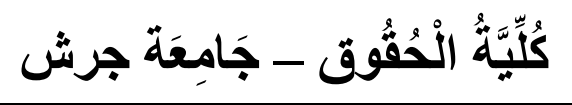

الملخص

تعد جر ائم الابادة الجماعية من الجر ائم القديمة التي عرفتها الانسانية وازداد ارتكابها بشكل خاص اثناء الحربين العالمتين الاولى والثانية لله> فقد تم تشكيل

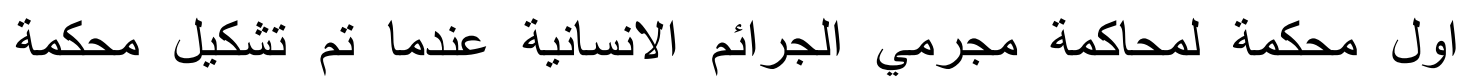

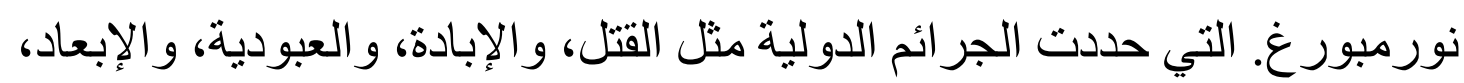

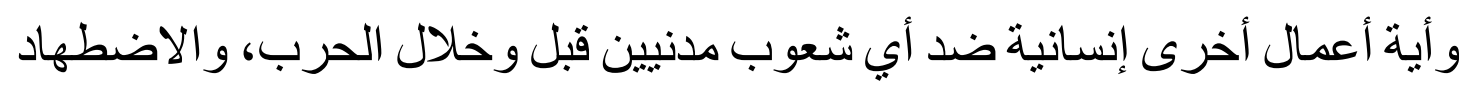
الذي بني على أسباب سياسية عرقية أو دينية عندما تتخذ هذه الأعمال القمعية

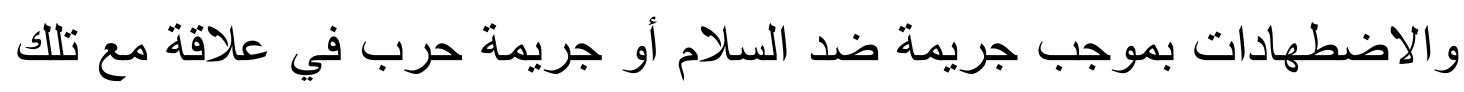
التصرفات. - الافط

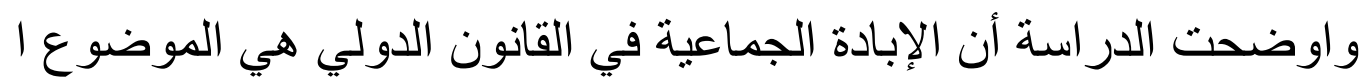

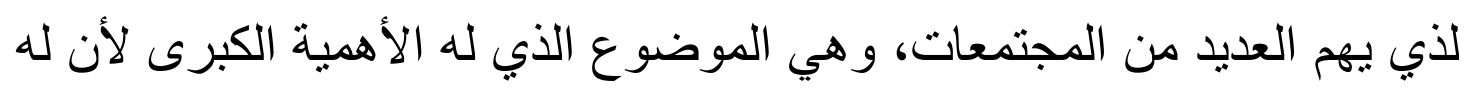

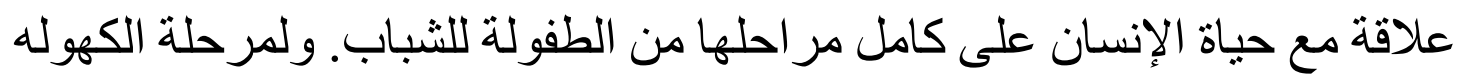
لكلا الجنسين.

وأكدت الدراسة على أن الجريمة الدولية ضد الإنسان هي الأخطر لأنها تمس حرية الإنسان وحقوقه وإنسانيته، مع التطرق لأركان جريمة الإبادة الإنة الإنة الإنة الإنة

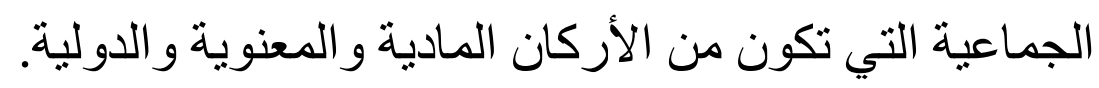

و تبدا اهمية الدر اسة في الوقت الحاضر ، في حالة الاضر اب و الفوضى التي

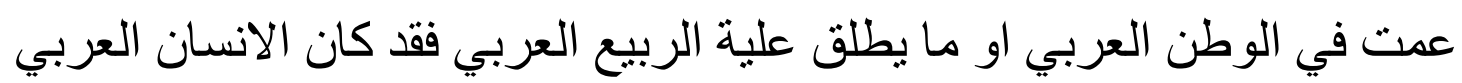

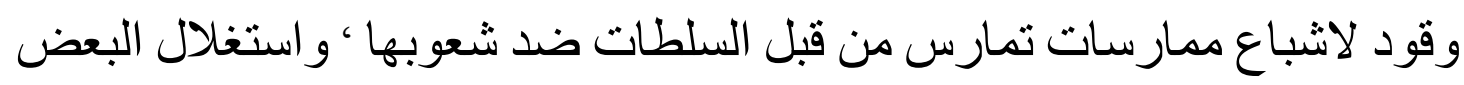


هده الظاهرة لارتكاب جرائم ارهابية لتدمير الدول من ناحية السياسية

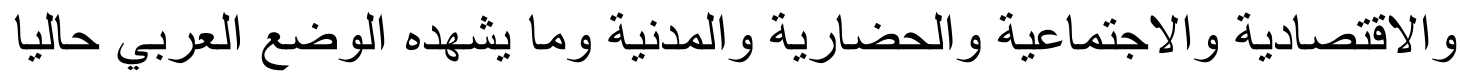

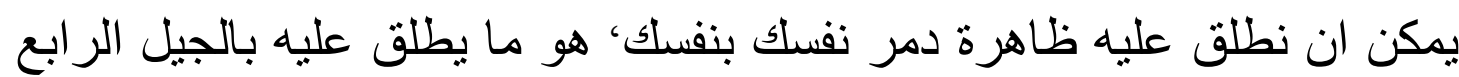

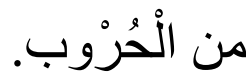


The Crime of Genocide

\begin{abstract}
The crimes of genocide are well known and oldest crimes against humanity. They have been increasingly committed particularly during World Wars I and II. The first court to prosecute criminals who committed crimes against humanity was when Nuremburg court was formed. This court identified international crimes against humanity such as murder, genocide, slavery, deportation, and any other acts against any civilian people before and during the war, and persecution which was built on political, ethnic or religious reasons.
\end{abstract}

The study showed that the genocide in international law, which is a subject matter of interest for many communities, a topic that has great importance because of its relationship with the human life stages from childhood to youth, adulthood and to both sexes.

The study confirmed that the international crime against human beings is the most dangerous because it affects human rights, freedom and humanity. It addresses the elements of the crime of genocide which is one of the physical, moral and international elements. The importance of this study is highlighted at the present time because of the chaos that pervades the Arab world, or the so - called Arab Spring. It was the Arab people who became fuel to satiate practices of the authorities against their people and exploit this phenomenon for some terrorist crimes to Arab destroy states in terms of political, economic, social, cultural and civil aspects. What the Arab world is witnessing now can be called a phenomenon of 'destroy yourself by yourself' or the so called fourth - generation of warfare. 


\section{مقدمة:}

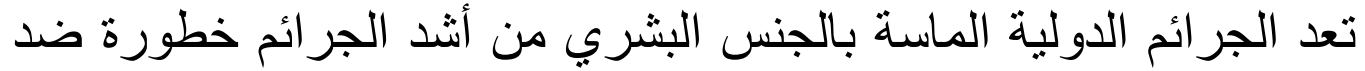

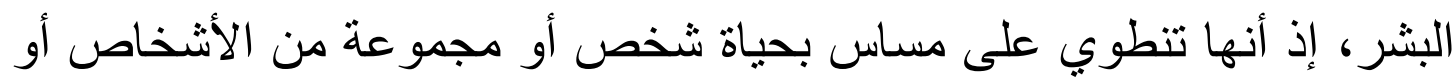
بحريتهم أو حقوقهم أو آدميتهم، وتنتكل تللك الجر ائم في مجمو عها ما يطلق عليه

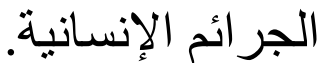

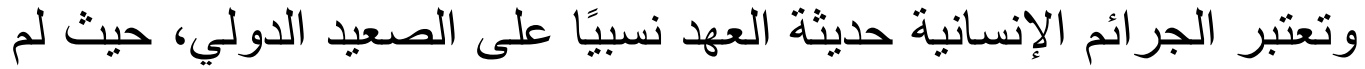

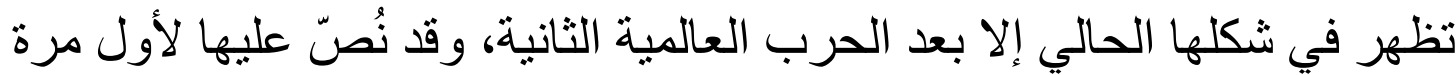

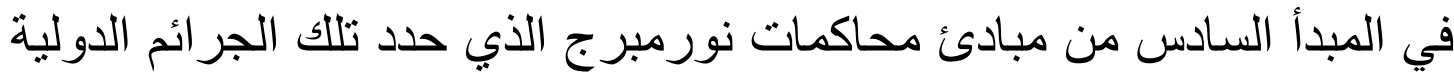

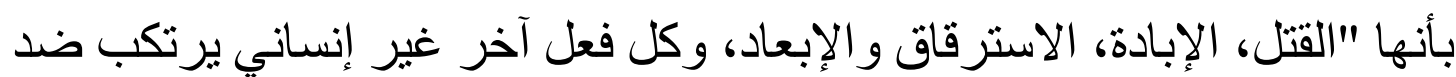

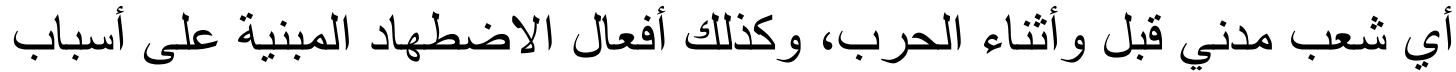

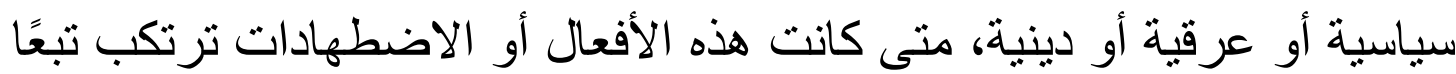
لجريمة ضد السلام أو جريمة حرب أو كانت ذات صلة التة بها (1) (1). وقد ذكرت مدونة مشروع الجر ائم ضد أمن وسلامة البشرية عام 1991 البران

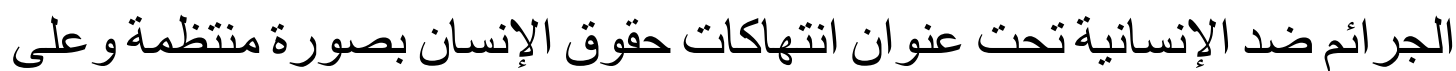

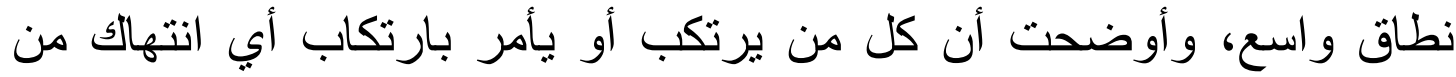

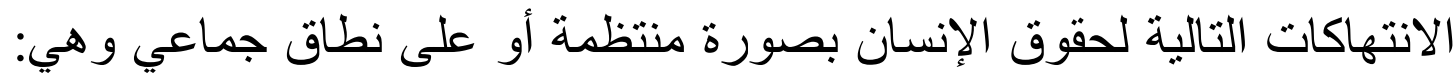

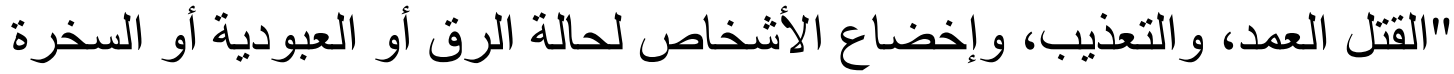

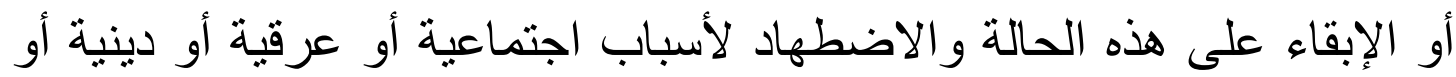

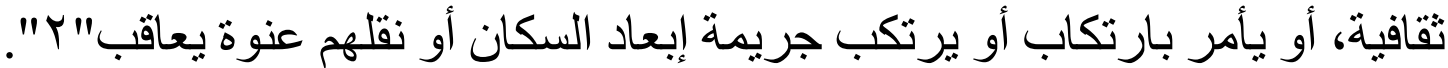

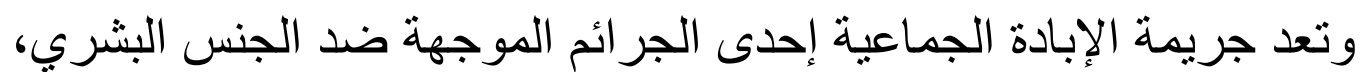

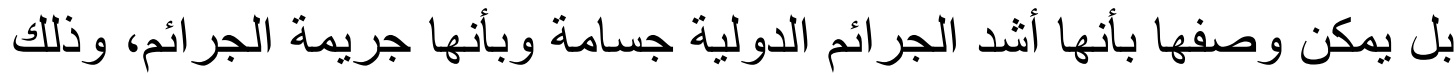

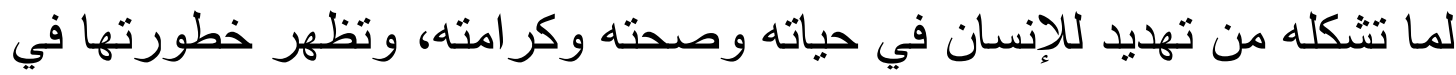

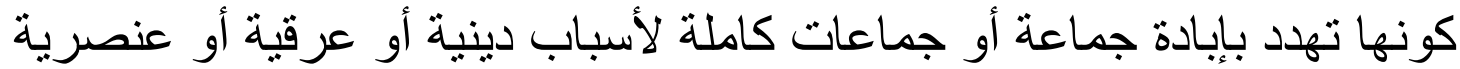

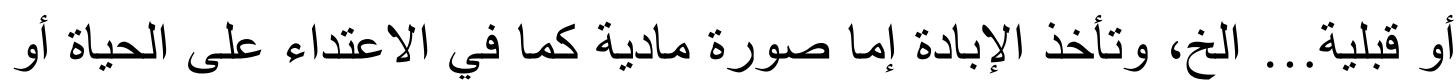

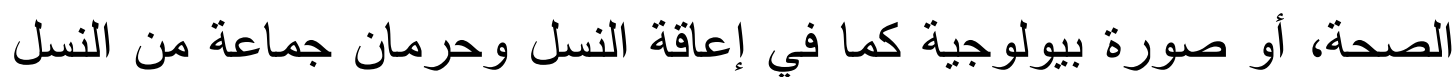


للتكاثر عن طريق التعقيم والإسقاط، أو تتصب الإبادة في صورة ثقافية كما في حرمان مجتمع ما من لغته أو نقافته.

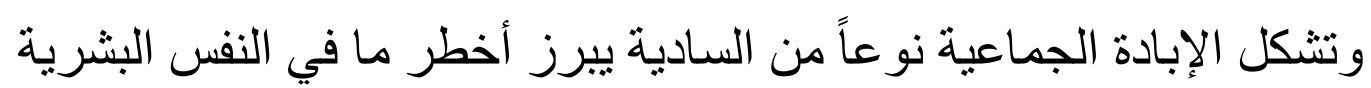

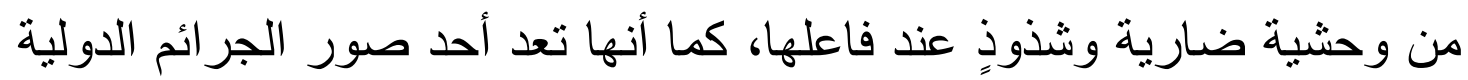

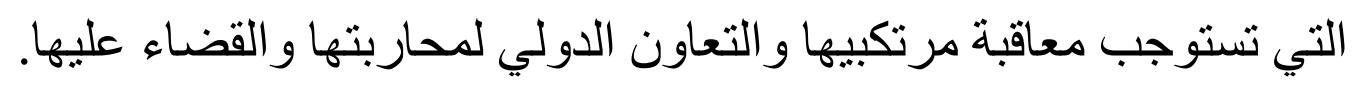

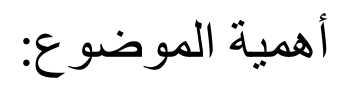

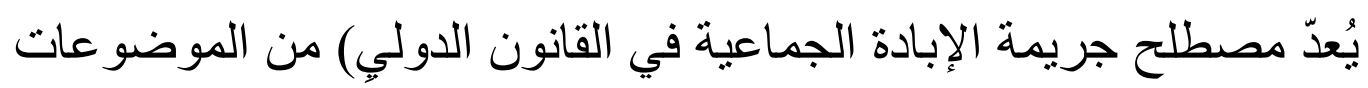

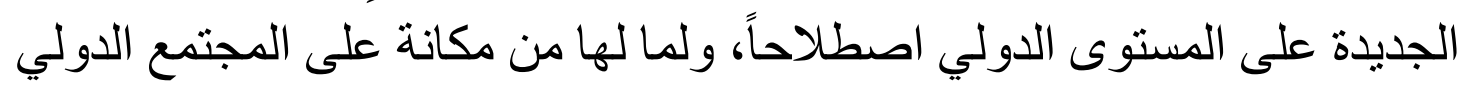

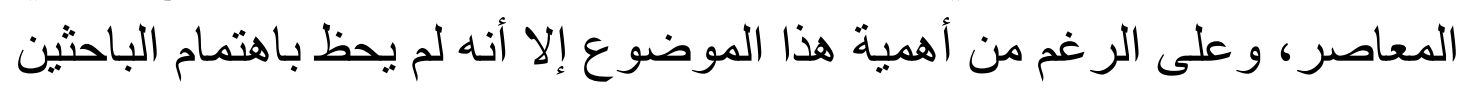

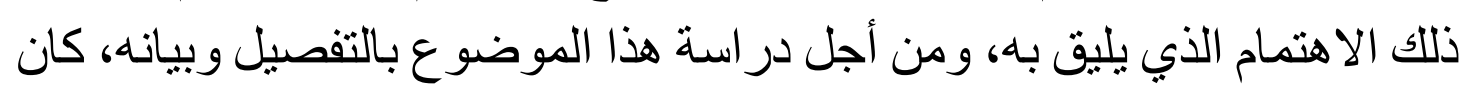
حرياً أن يدرس دراسة متكاملة، في القانون الدولي.

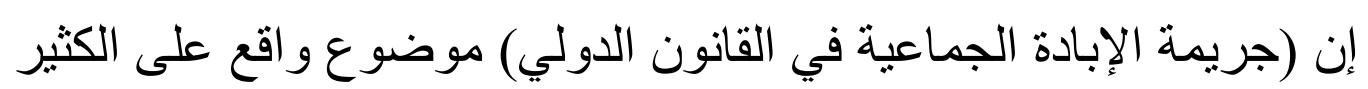

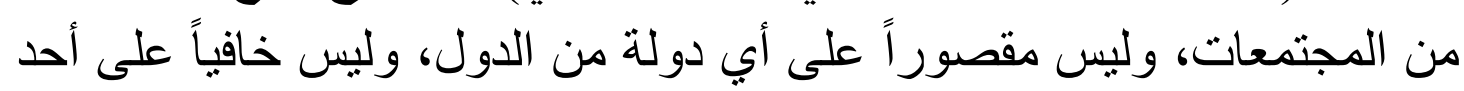

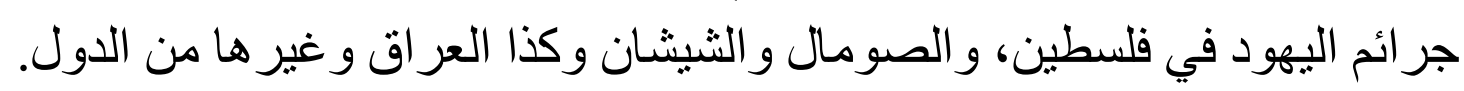

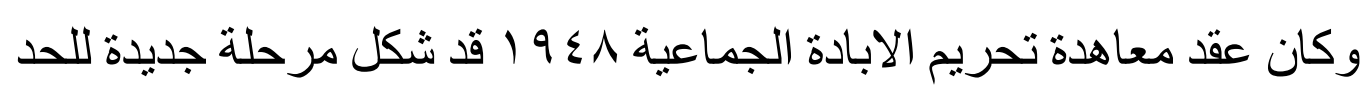

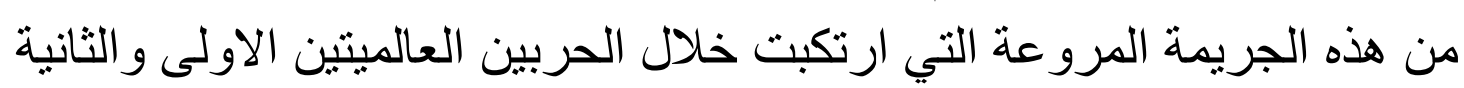

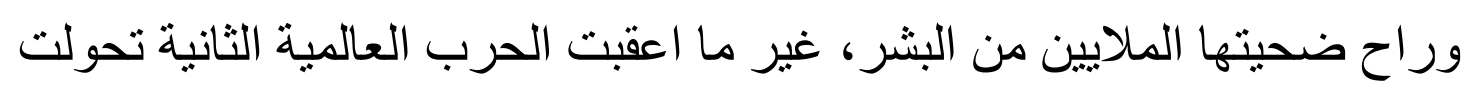

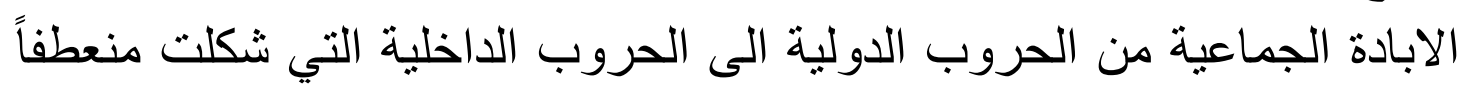

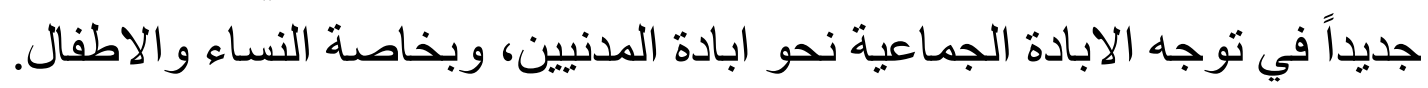

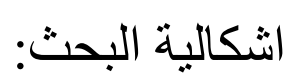

إن ما تضمنته معاهدة تحريم الابادة الجماعية المعقودة 7 ـ 9 ا وما جاء بنظام

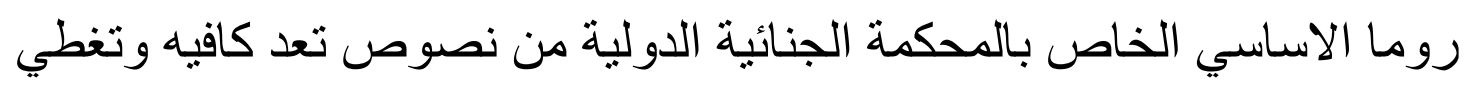

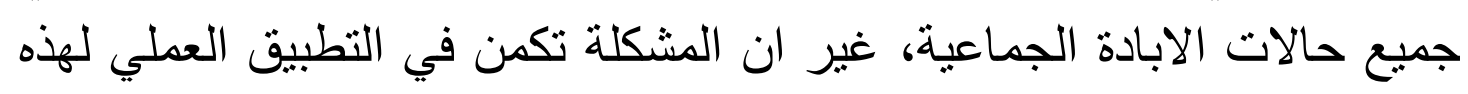

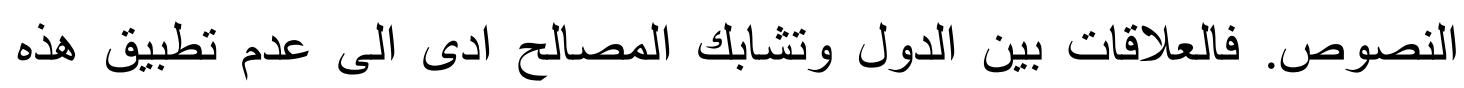

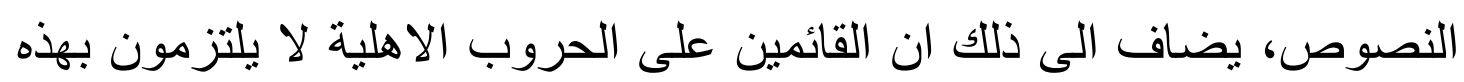
القو اعد مما ادى الى زيادة حالات القتل بين الددنيين

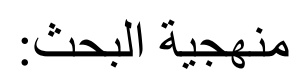


إن الركيزة الرئيسية لمنهج البحث قامت على استخدام الأسلوب التحليلي التأصيلي للنصوص و القوانين الني نظمت هذه الدراسة النة، لفهم أبعادها، وبيان

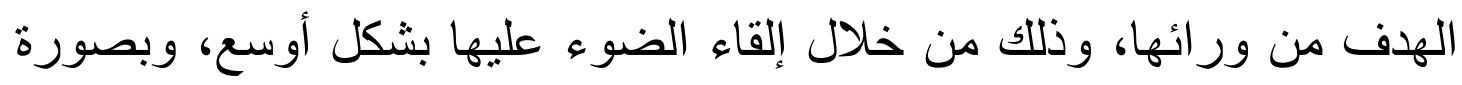
موضوعية، بهدف استجلاء حقيقتها، وبيان موقف الباحثين تجاهها، فيما يتصل التهل بما فيها من ثغرات قانونية من خلال أحكام المحاكم الجنائية الدولية الخاصة، و الإشكاليات المتصلة بها. وبناء على ذلك فهذا البحث بعد دراسة تحلية اليلية تطبيقية لقو اعد تحريم ابادة الجنس البشري.

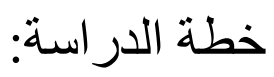

تطلب البحث تقسيمه إلى ثلاث موضو عات، الأول جريمة الإبادة الجماعية،

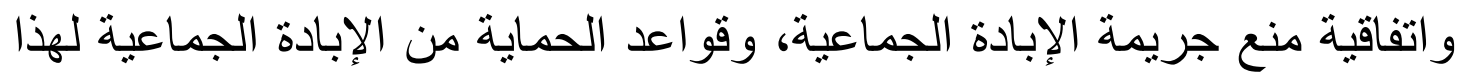

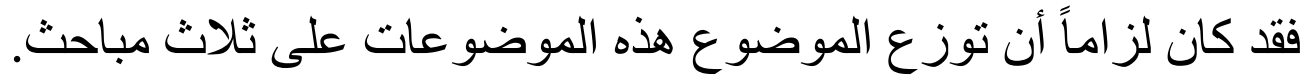

\section{المبحث الأول جريمة الإبادة الجماعية كجريمة دولية}

تعتبر جريمة إبادة الجنس البشري حديثة العهد في القانون الدولي الجنائي،

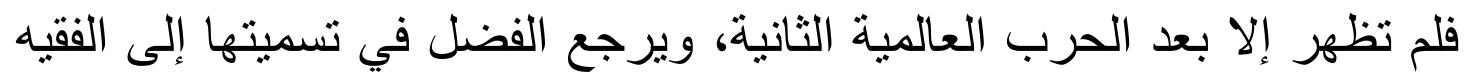

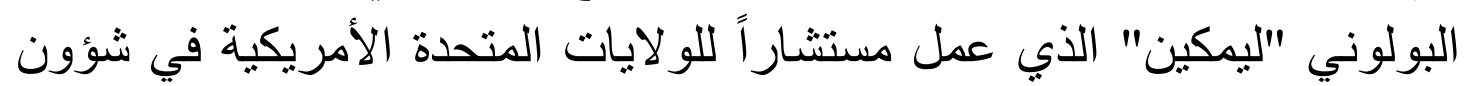
الحرب في نهاية الحرب العالمية الثانية.

كما وفر القانون الى الحماية للإنسان، واعتبر أن الاعتداء عليه يثكل جريمة

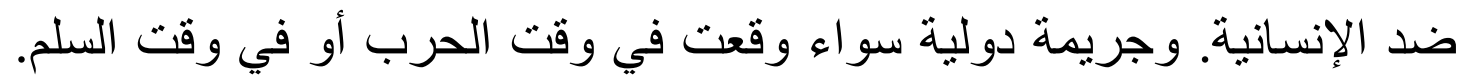

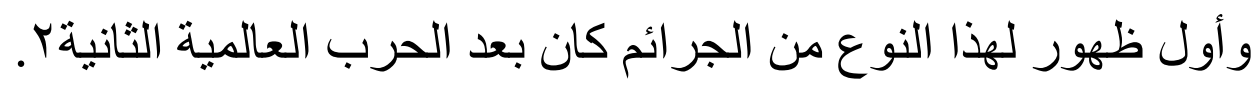

$$
\text { المطلب الاول }
$$

اركان جريمة الابادة الجماعية

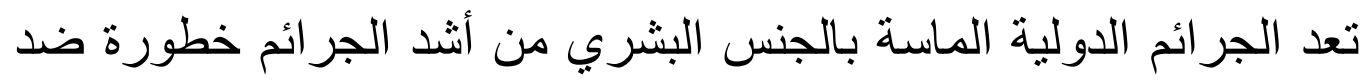

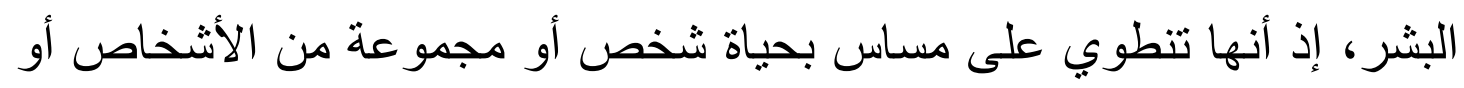


بحريتهم أو حقوقهم أو آدميتهم، وتثكل تلك الجرائم في مجمو عها ما يطلق عليه

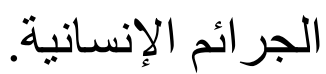

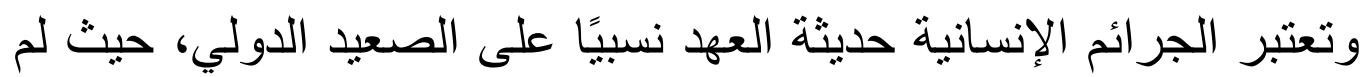

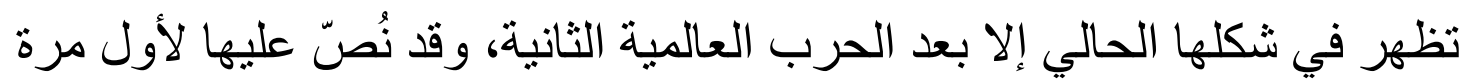

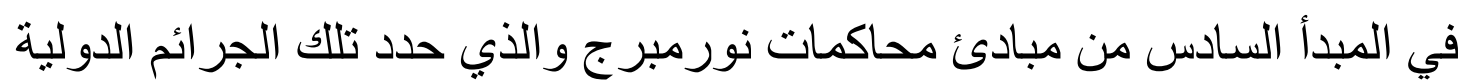

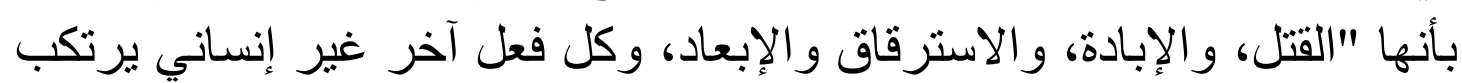

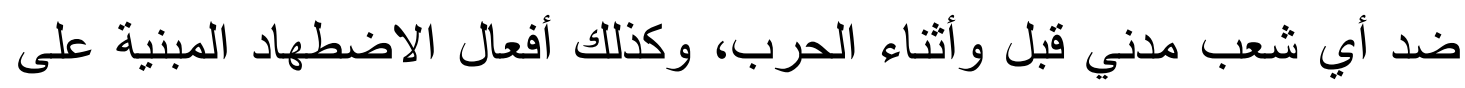

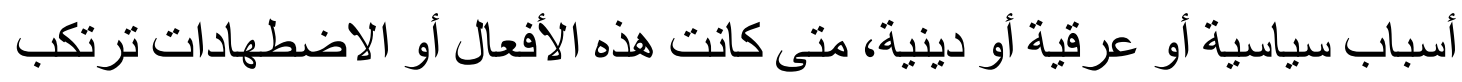

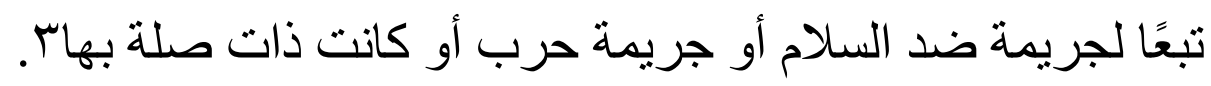
وقد ذكرت مدونة مشروع الجرائم ضد أمن وسلامة البشرية عام 1991

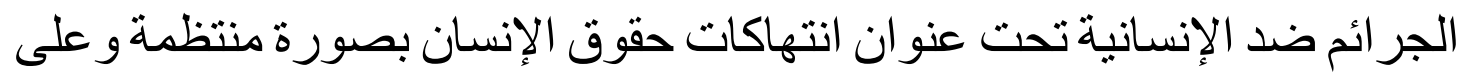

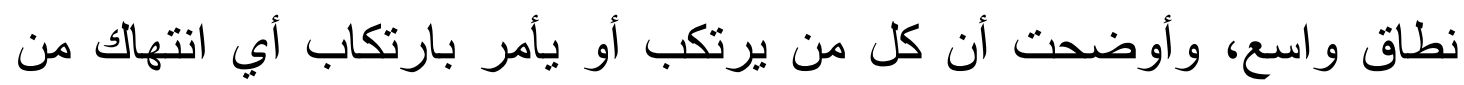

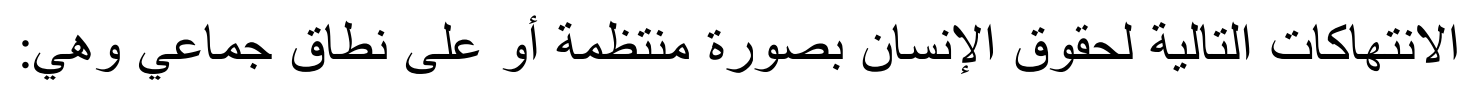

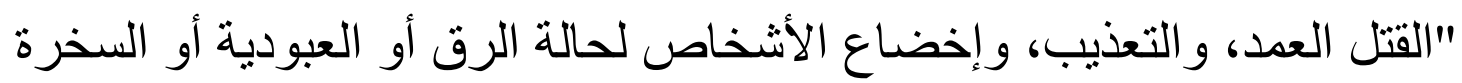

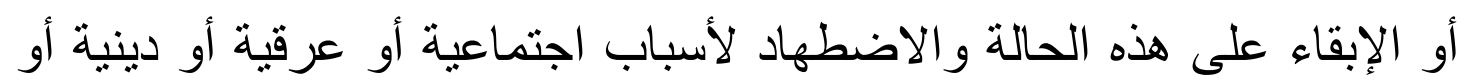

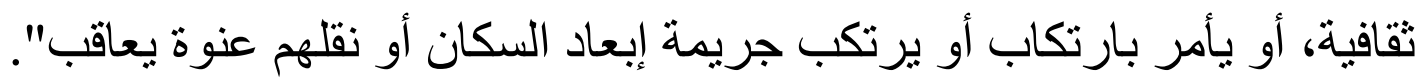

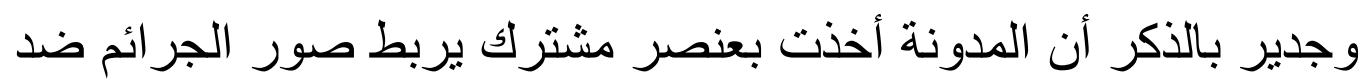

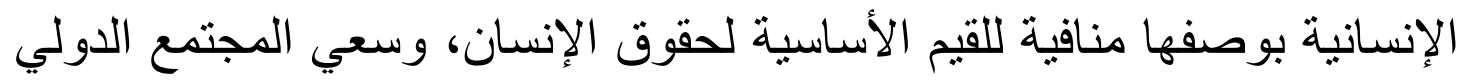

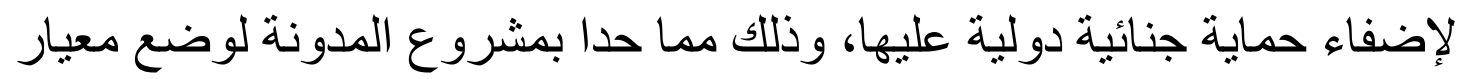

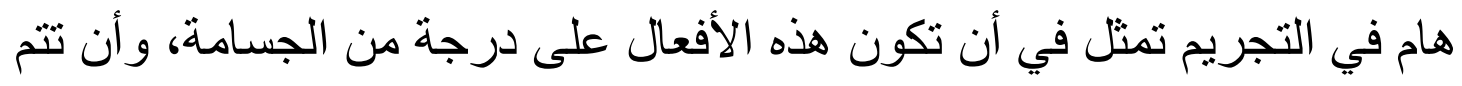

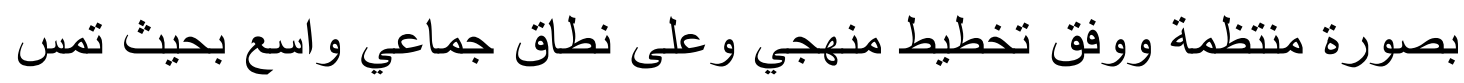

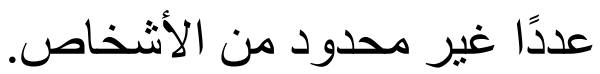

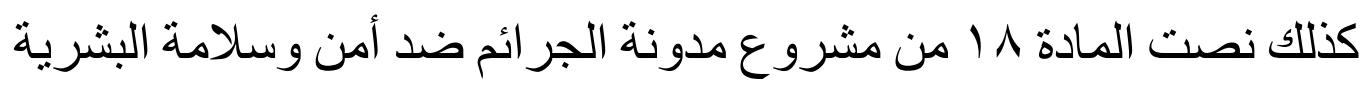
لعام 1997 على تعريف الجرائم ضد الإنسانية وتحديد صور ها بأنها "كل فعل التحل

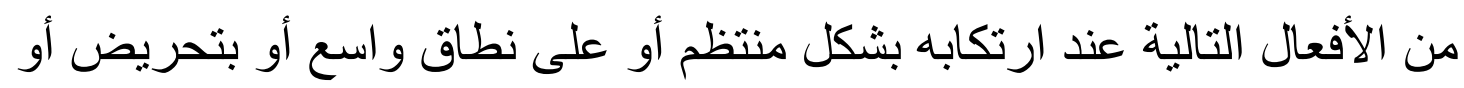

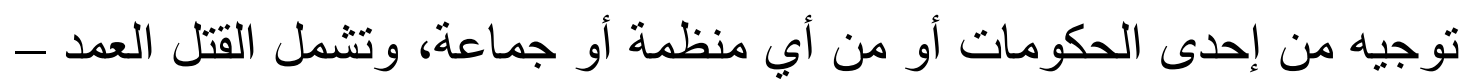

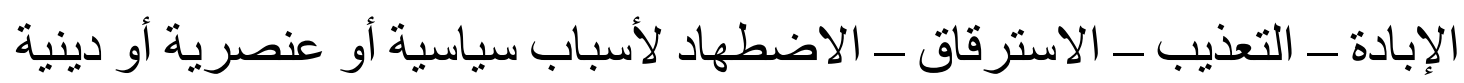

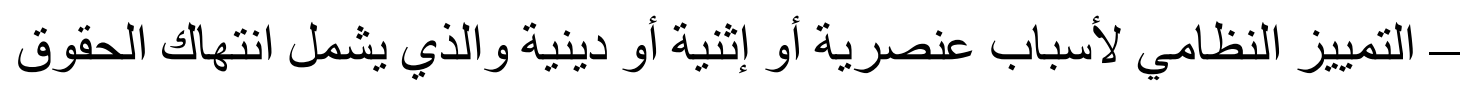


و الحريات الأساسية للإنسان ويؤدي إلى ضرر جسيم بجزء من السكان - الإبعاد التعسفي أو القتل القسري للسكان - الاحتجاز التعسفي - الإخفاء القسري للأشخاص - الاغتصاب و الدعارة القسرية والأشكال الأخرى من الاعتداء

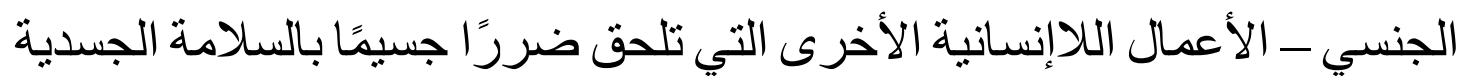
أو العقلية أو بالصحة العامة أو بالكرامة الإنسانية مثل التشويه والإصـابات الجسدية الجسيمة.

وقد جاءت تللك المدونة على ذات نهج مدونة الو9 (، إلا إنها أضافت لها

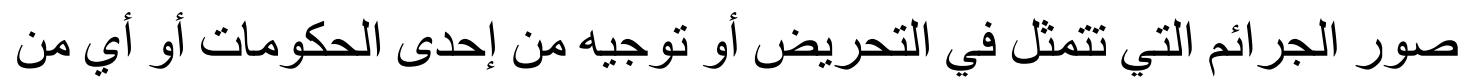
المنظمات أو الجماعات، مع استبعاد الحالات التي ترتكب فيها تللك الجرائم بواسطة فرد بتصرف ذاتي منه دون دعم أو تشجيع أو توجيه من حكومته أو الو جماعته.

وتعد جريمة إبادة الجنس البشري إحدى الجرائم الموجهة ضد الجنس

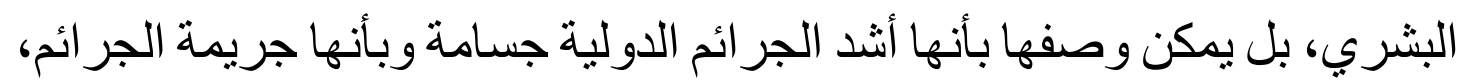
وذللك لما تشكله من تهديد للإنسان في حياته وصحته وكر امته، وتظهر خطور بانها ونها

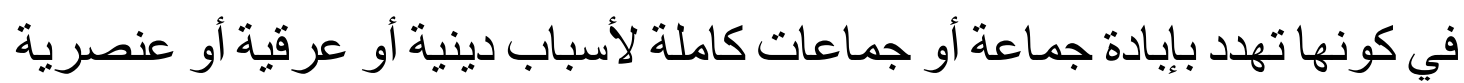

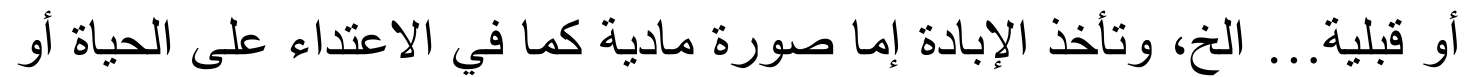

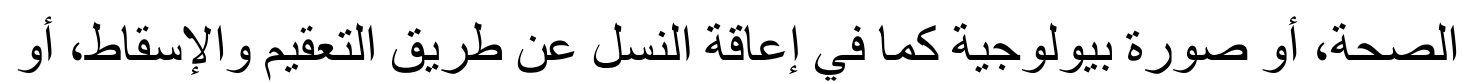
تتصب الإبادة في صورة ثقافية كما في حرمان مجتمع ما من لغته أو ثقافته. وتعتبر جريمة الإبادة الجماعية من الجرائم التي تمتد جذور ها عبر التاريخ

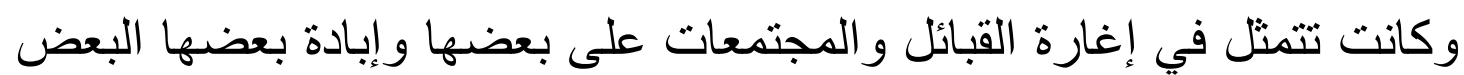
تطلعًا للغنائم و الثرو ات و والنفوذ إغدارة

أما أول ظهور لمصطلح الإبادة الجماعية فقد استخدمه الفقيه ليمبكن في دراسة أعدها عام ؟ 9 ا لتوضيح خصوصية الجرائم المرتكبة من النازيين و الفظائع التي مارسو ها ضد الإنسانية خاصة تللك الأفعال الهادفة لتدمير دول التهات أوروبا الو اقعة تحت الاحتلال النازي، و إلى جرمنة هذه الإنهائ الدول، وقد ابتدع ليميكن

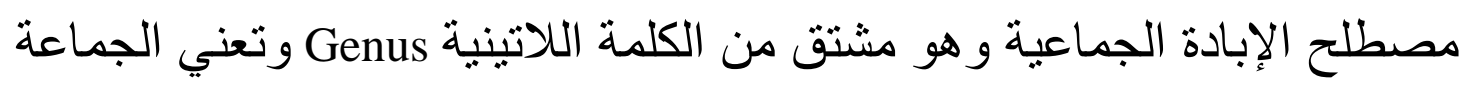

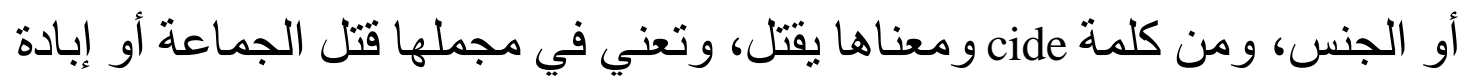
الجماعة، وقد أطلق هذا الفقيه على تللك الجريمة فيما بعد مصطلح جريمة الجر ائم 


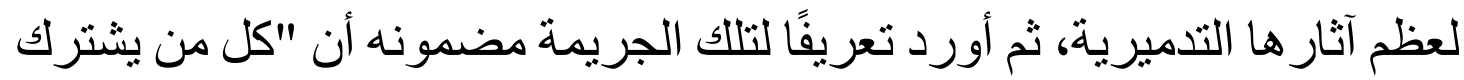

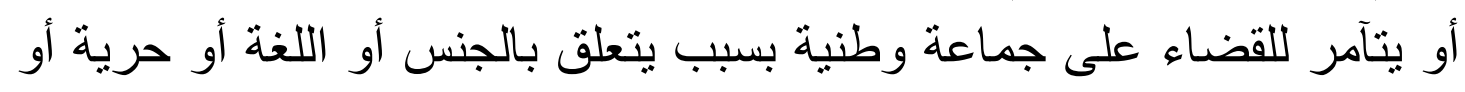

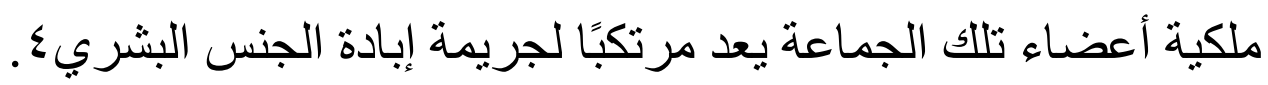

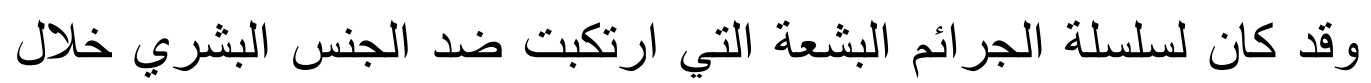

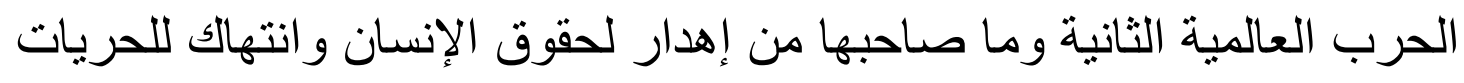

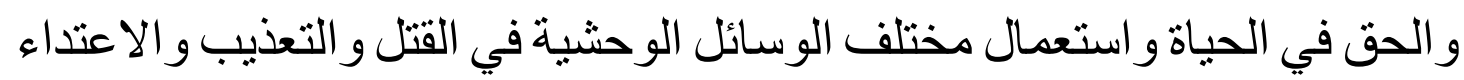

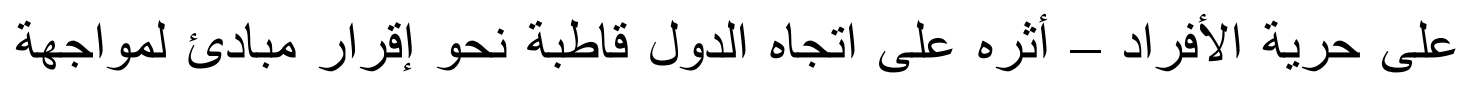

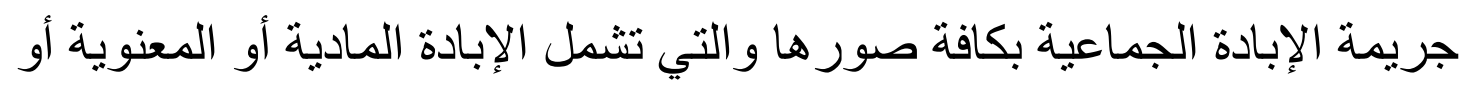
الثقافية.

ومن صور جريمة الإبادة الجماعية أثناء الحرب العالمية الثانية القنبلة

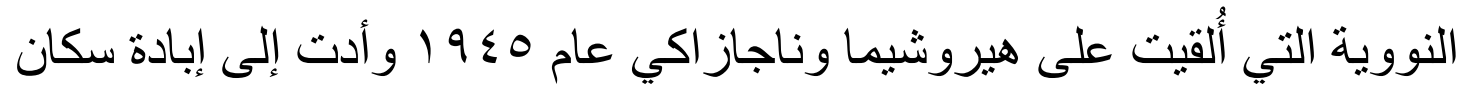

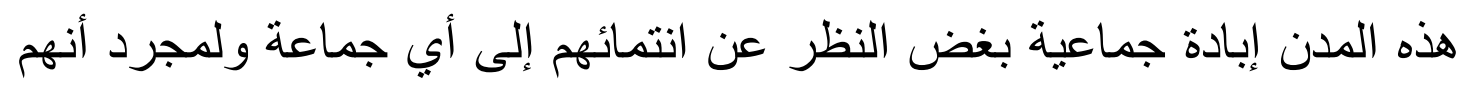

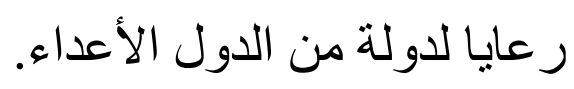

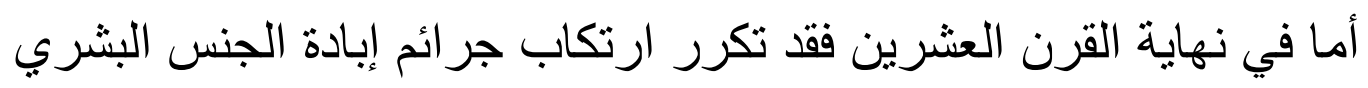

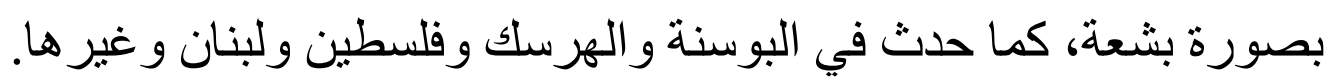
أَوَّلاً - المصطلحات الخاصة بالإبادة الجماعية جرائم الإبادة الجماعية، أو جرائم إبادة الجنس البشري أو جرائم إبادة

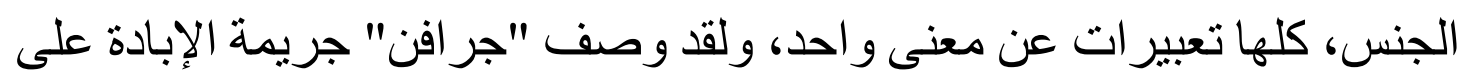

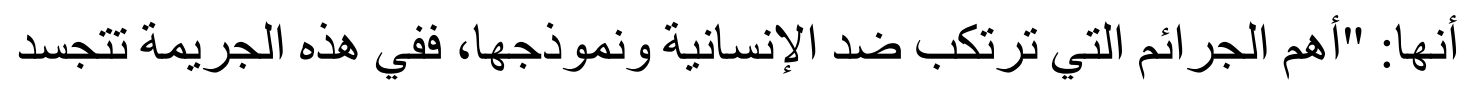

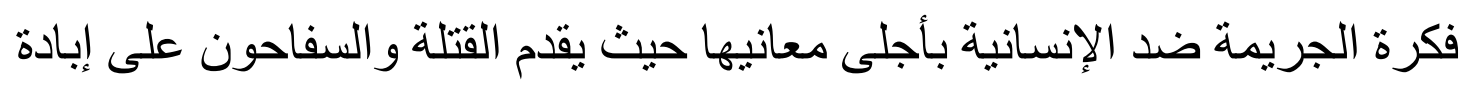

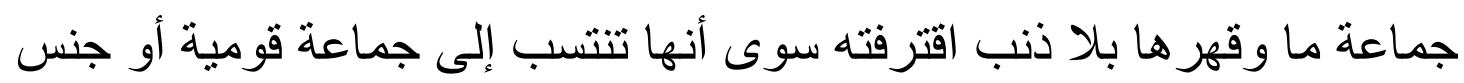
أو دين يخالف قومية أو جنس أو دين القتلة".

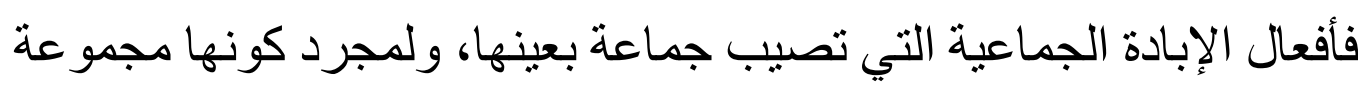

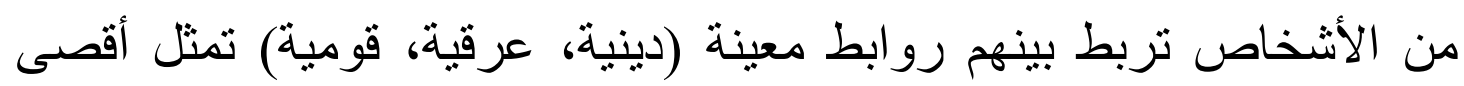

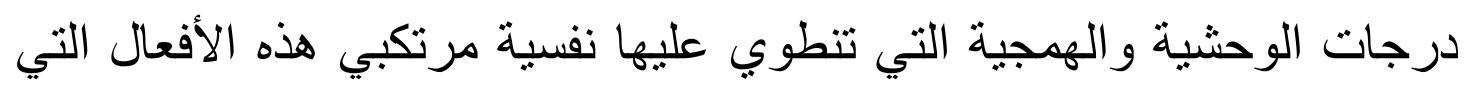

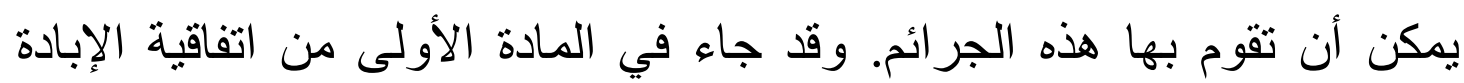

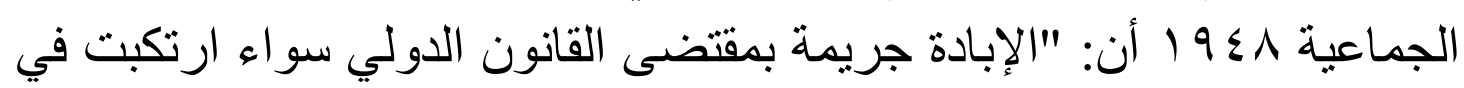
وقت السلم أو في وقت الحرب، ونتعهد الدول الأطر اف بمنعهاو المعاقبة عليها"ه. 
وجريمة الإبادة الجماعية شأنها شأن باقي الجرائم الدولية، تقوم على الأركان

$$
\text { أركان جريمة الإبادة }
$$

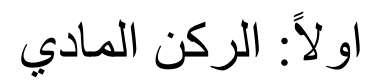

نكون بصدد الركن المادي لجريمة إبادة الجنس البشري إذا توافرت أحد

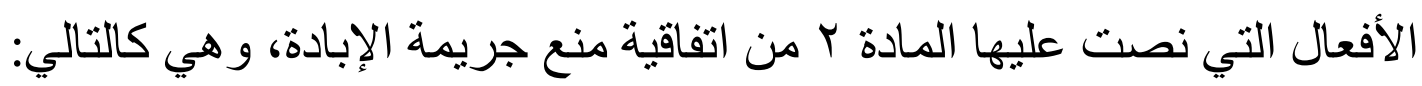
1 إقتل أفر اد أو أعضاء الجماعة:

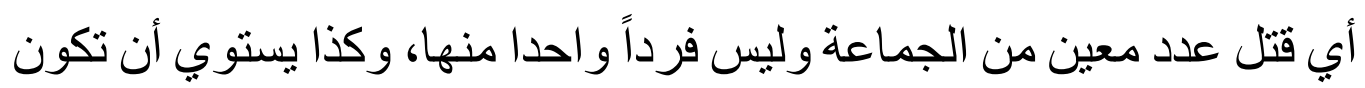
الإبادة جماعية أو جزئية، كما يستوي كذلك وقوع الفعل بصفة إيجابية أو سلبيةجا. r-إلحاق أذى أو ضرر جسدي أو عقلي خطير بأعضاء الجماعة:

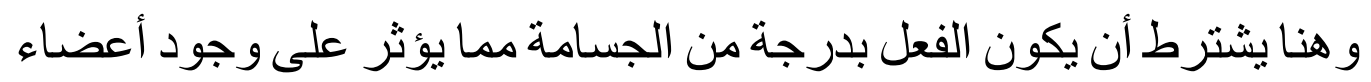
الجماعة، ويتحقق هذا الفعل بكل وسيلة مادية أو معنوية لها تأثئير على أعضى أعضاء الجماعة مثل الضرب أو التشويه الذي يفضي إلى عاهات مستديمة أو التعذيب. r- إخضاع الجماعة لظروف معيشية قاسية يقصد منها إهلاكها أو تدمير ها الفعلي

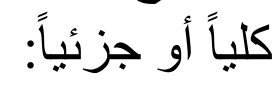
ومثال هذا الإقامة في مكان خال من كل سبل الحياة حيث لا زر ع و و لا ماء،

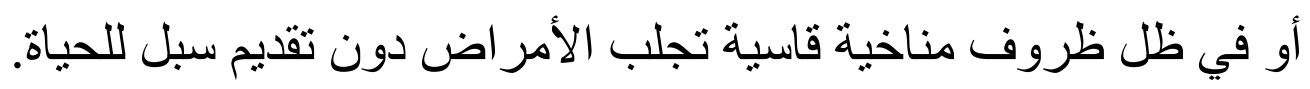
ع-فرض تدابير ترمي إلى منع أو إعاقة النسل داخل الجماعة:

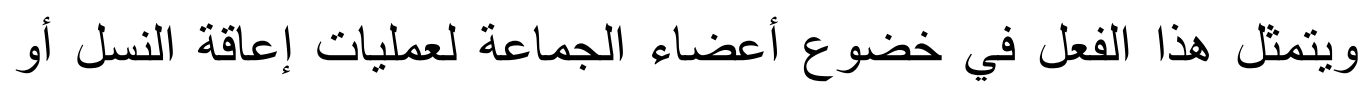

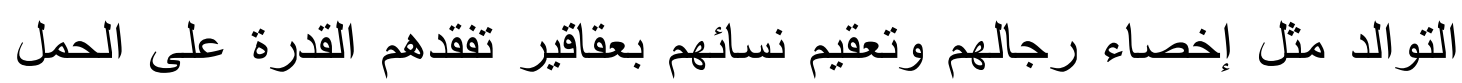

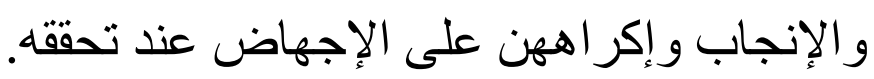

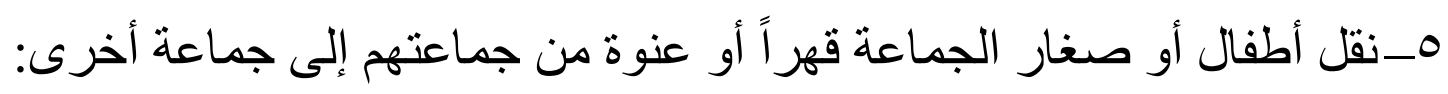

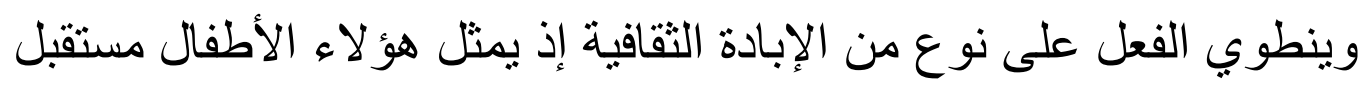

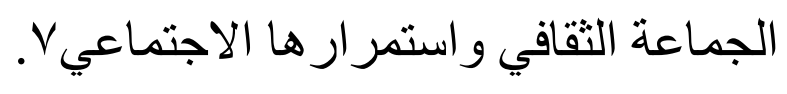

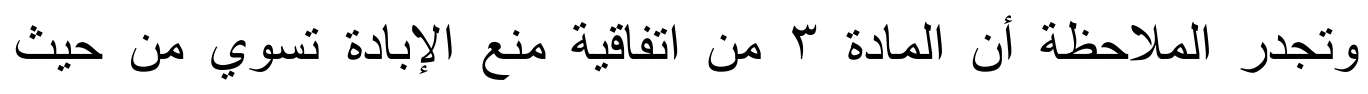

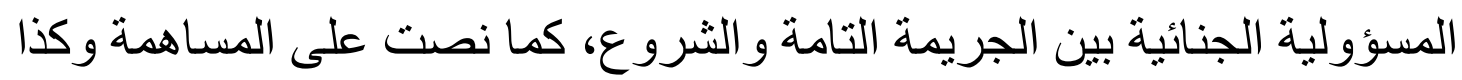

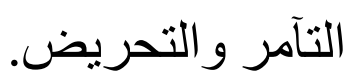


ثانياً: الركن المعنوي

يتطلب الركن المعنوي لهذه الجريمة ضرورة توفر القصد الجنائي الخاص،

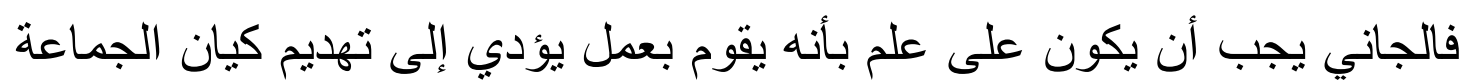

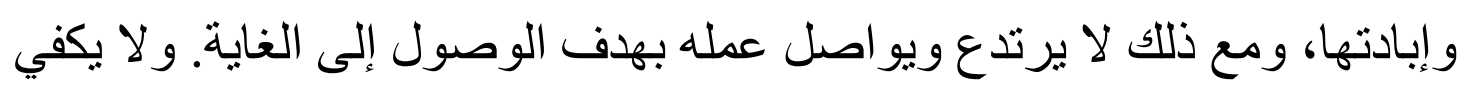

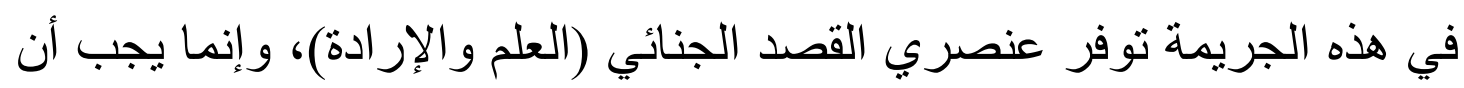

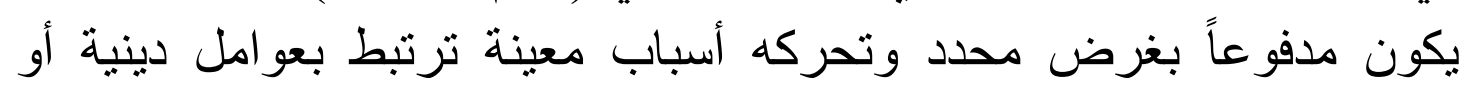
عنصرية أو جنسية.

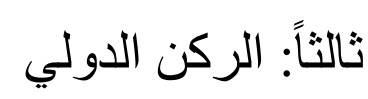

غالبا ما تكون هذه الجريمة هدبرة من قبل الحكام أو فئات اجتماعية سائدة

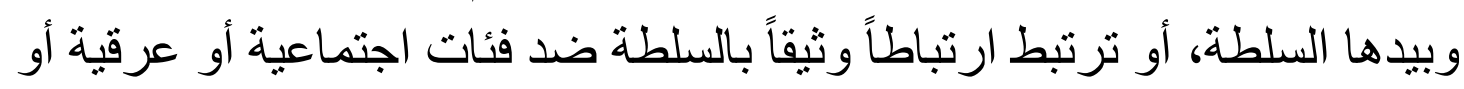

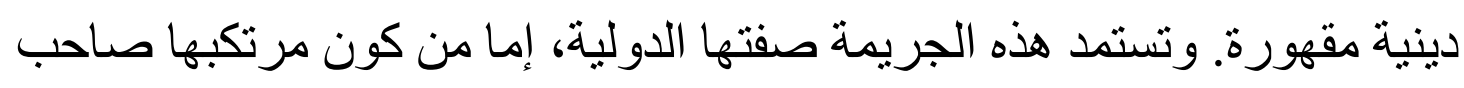

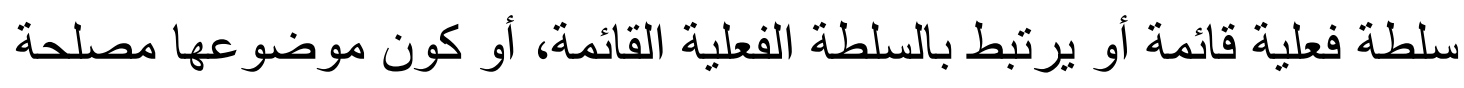

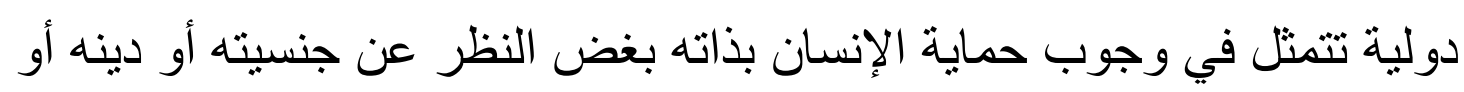

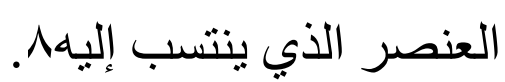

\section{الْمَطْلَبُ الثالث \\ تاريخ جريمة الإبادة الجماعية}

بادئ ذي بدء علينا أن نعرف جرائم الإبادة الجماعية على مدار التاريخ،

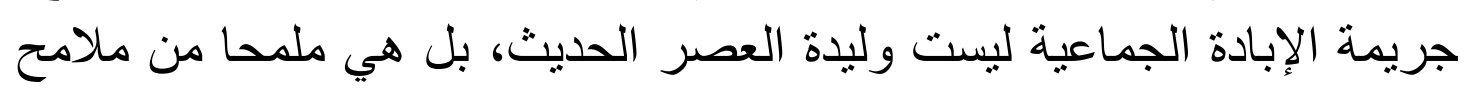

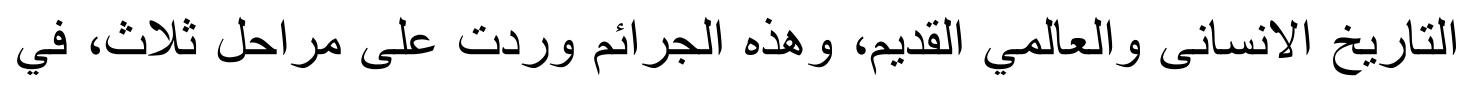

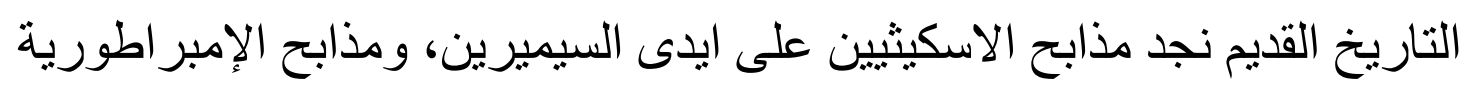

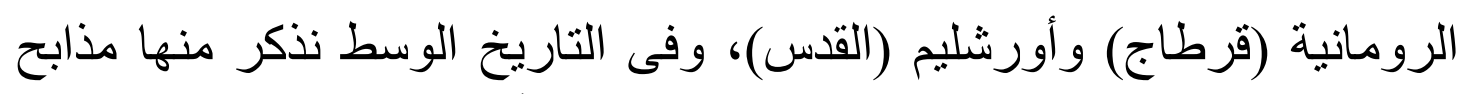

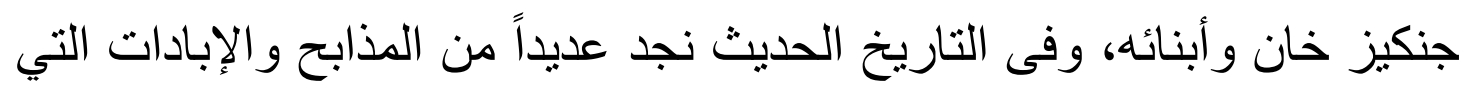

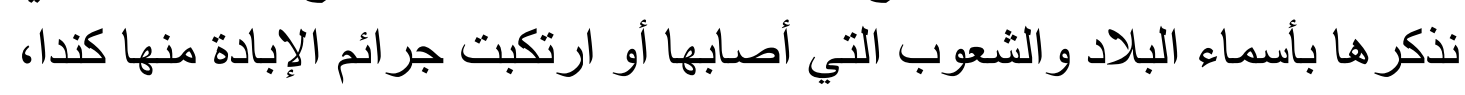

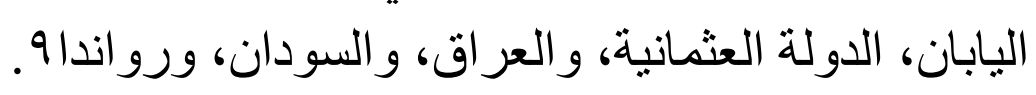

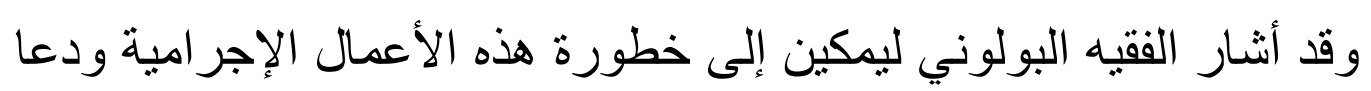

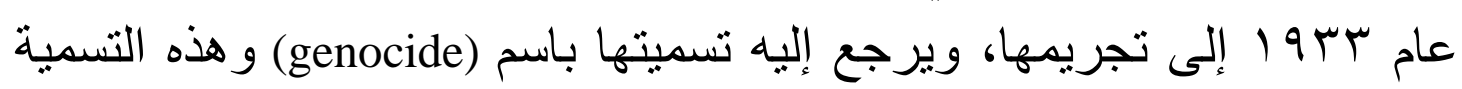


أصلها يوناني (genos) و التي تعنى الجنس، و (cide)و التي تعنى القتل، وباللغة

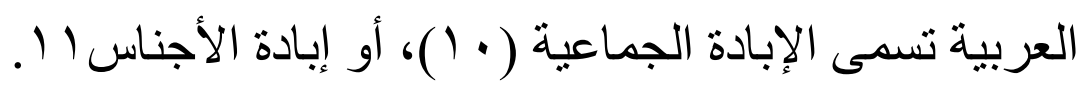
و التاريخ بأكمله مليئ بالأمثلة عن جر ائم الإبادة الجماعية و التي آخر ها في

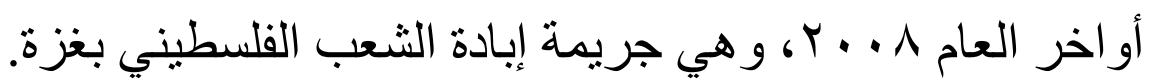

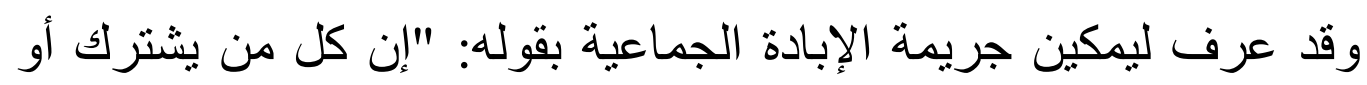

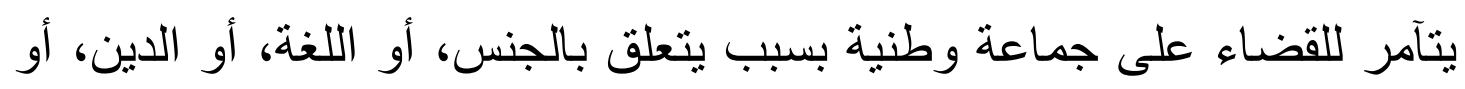

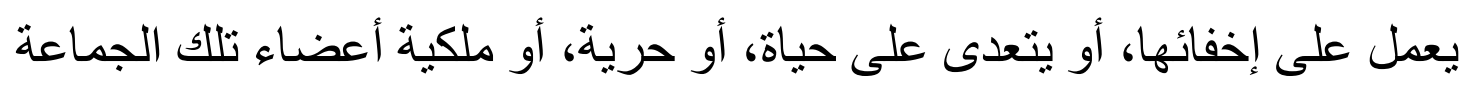

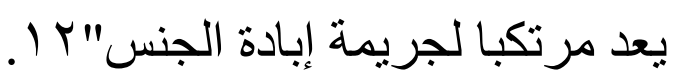

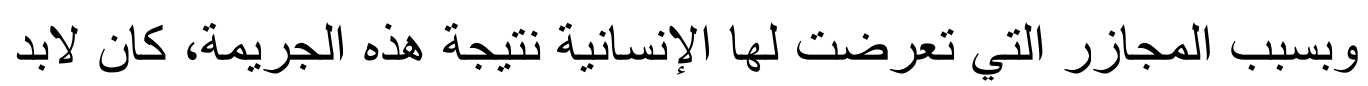

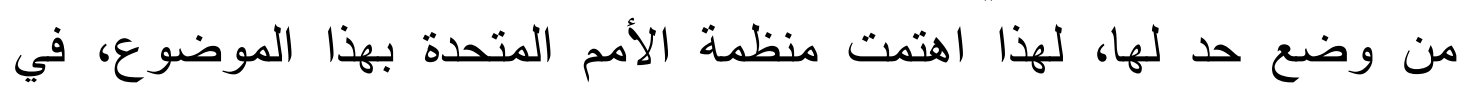

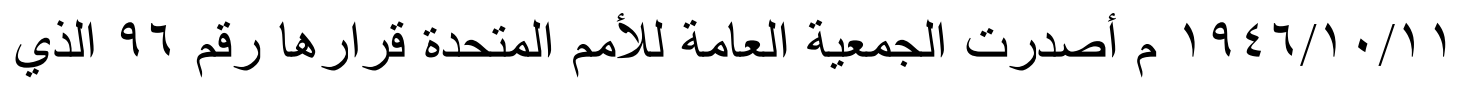

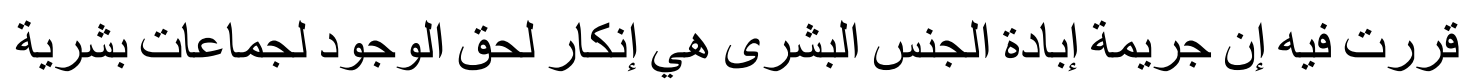

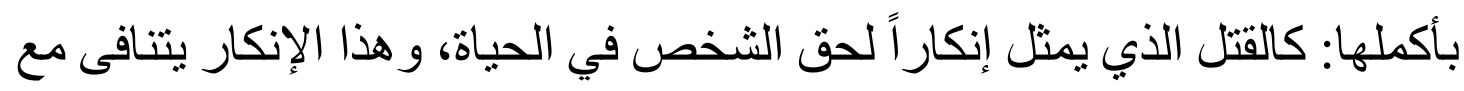
الضمير العام ويصيب الإنسان بإضر ار جسيمة من ناحية ومن ناحية أخرى تعتبر هذه الجريمة جريمة دولية وفقا للقانون الدولي، وتتعارض باضِ مع رو روح الأمم المتحدة

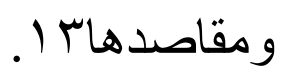

وتم عرض مشروع القرار على أعضاء الأمم المتحدة، وتمت المو افقة عليه

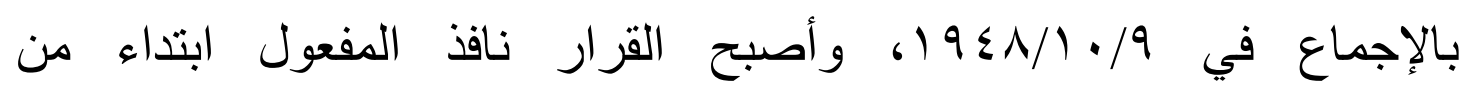
م) $901 / 1 / 1 \mathrm{r}$

كما ورد في المادة الأولى منها، إن الإبادة الجماعية هي جريمة بمقتضى إنى الني القانون الدولي، سواء ارتكبت في وقت السلم أو أثناء الحرب، وتتعهد تللك الدول

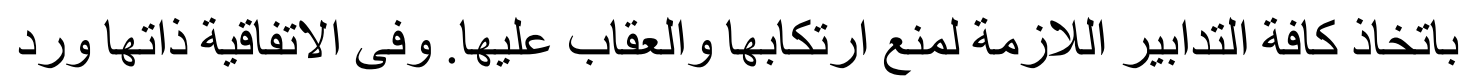

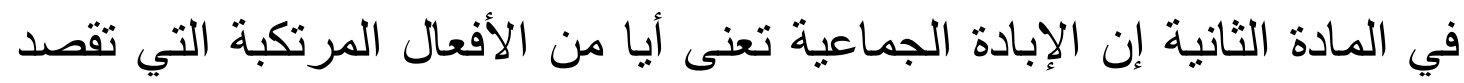
التدمير الكلى أو الجزئي لجماعة قومية أو أنتية أو عنصرة أنماعية أو أو دينية. كما تبين أن جريمة الإبادة مصدر ها العرف الدولي وهو الأمر الذي جعل إحكام هذه الاتفاقية ملزمة لجميع الدول حتى غير المصدقة عليها، والئ وأيضا يتصور وقوع جريمة الإبادة في وقت السلم أو أثناء الحرب، ولأهية لأهميتها لم يتم إلحاقها

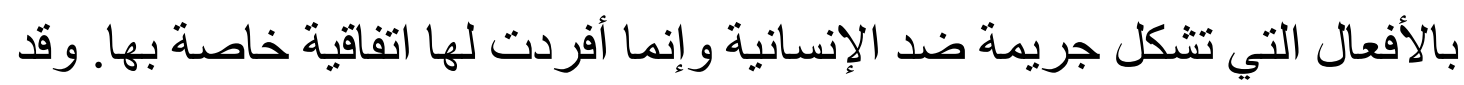




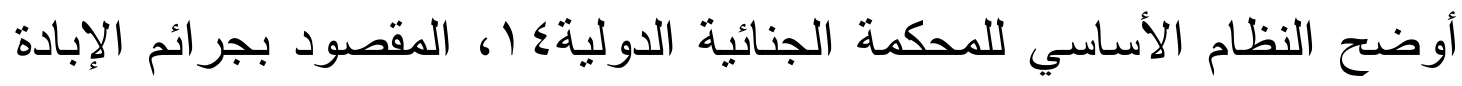

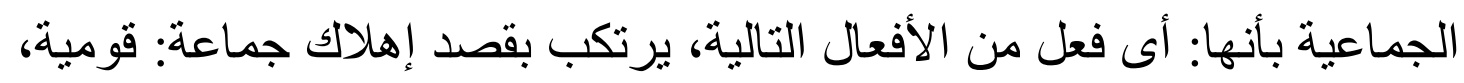

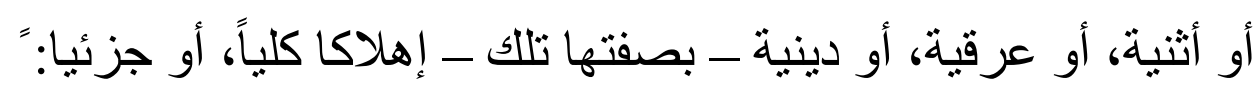

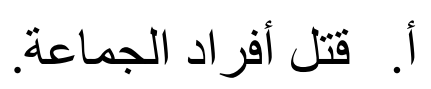

ب. إلحاق ضرر جسدي، أو عقلي جسيم بأفر اد الجماعة.

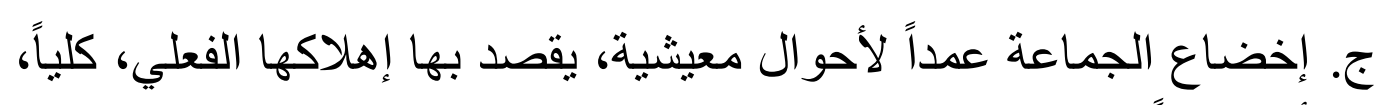

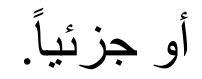

د. فرض تدابير، تستهدف منع الإنجاب داخل الجماعة. هـ. نقل أطفال الجماعة عنوة إلى جماعة أخرى.

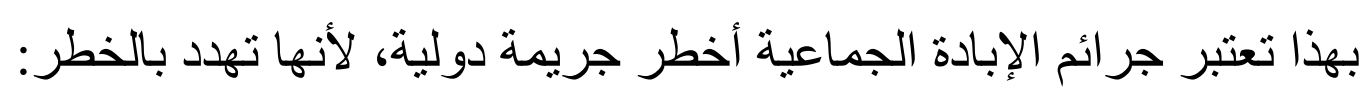

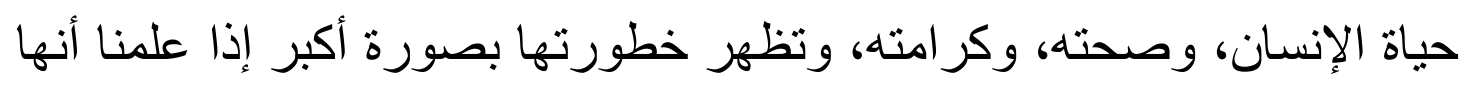

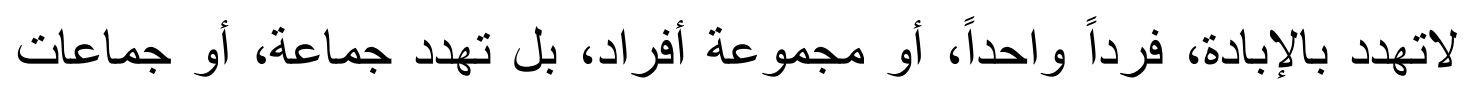
كاملة، لأسباب: قومية، أو اثثنه، أو عرقية، أو دينية.

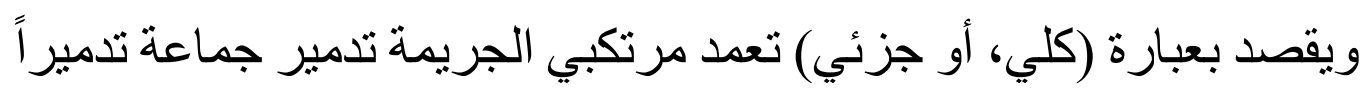

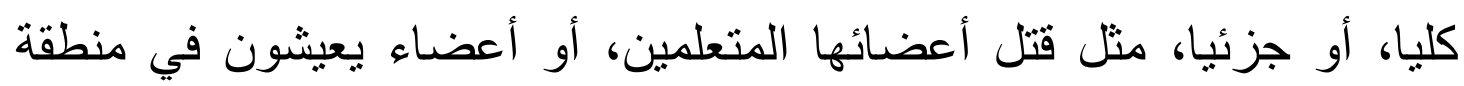
واحدة).

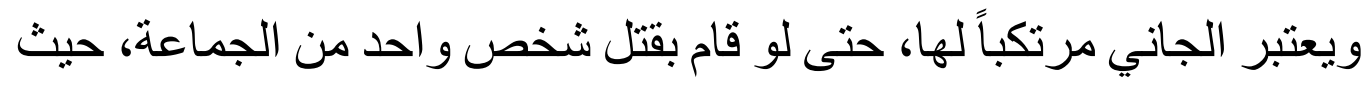

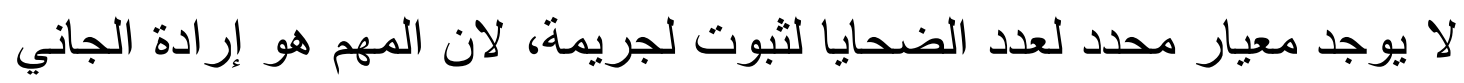

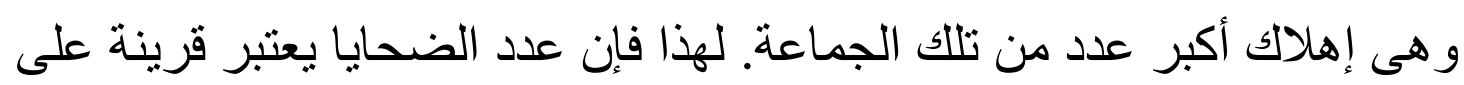
نية الإبادة، وللمحكمة سلطة تقديرية و اسعة في تقييم هذه القرينة. نشير بإيجاز ابرز أنوع الإبادة الجماعية والتي نوردها في النقاط الآتية:

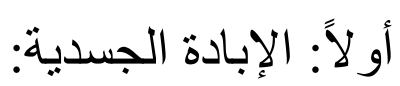

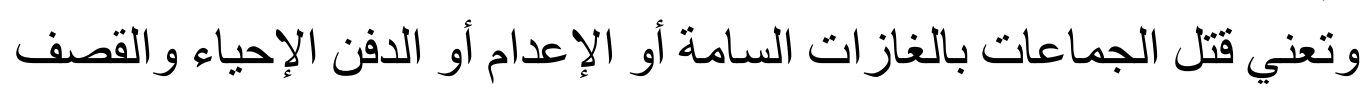

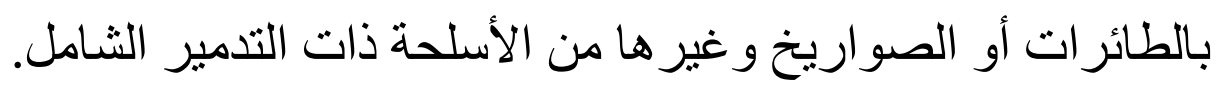
ثانياً: الإبادة البيولوجية:

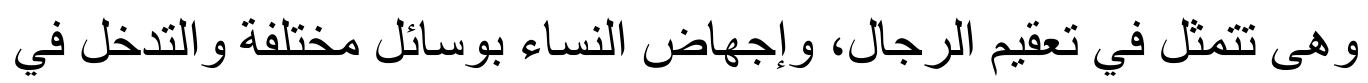
تغيير الخلقة الإنسانية لأهداف سياسية ودينية للقضاء على العنصر البشرى. 
ثالثاً: الإبادة الثقافية:

و هى منمنلة في عدم التحدث باللغة الوطنية، والاعتداء على التقافة القومية.

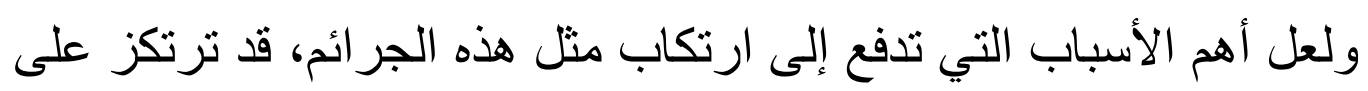

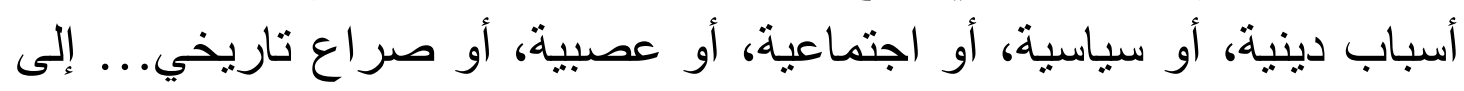

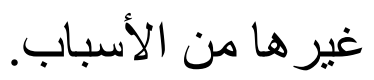

\section{المطلب الرابع \\ الطبيعة الدولية لجربمة الإبادة الجماعية}

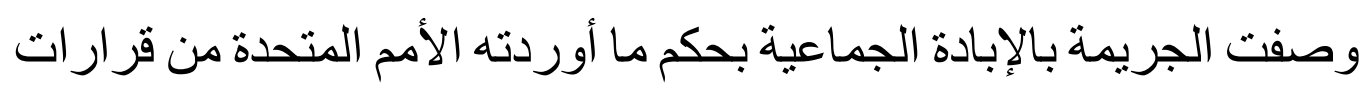

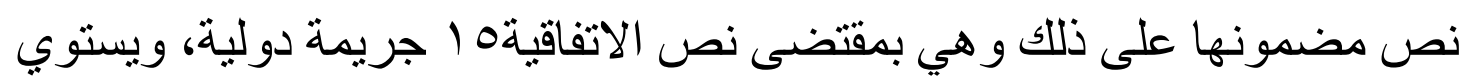

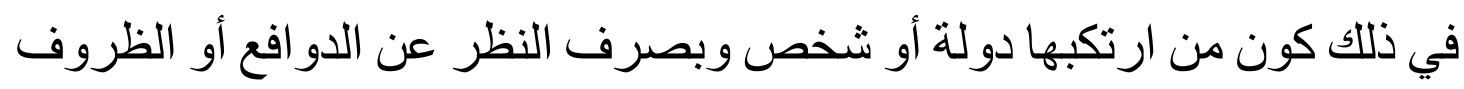
(كالحرب أو السلم) فهي مجرمة متى وأين حدثت. ولكنها استمدت صفة الدولية

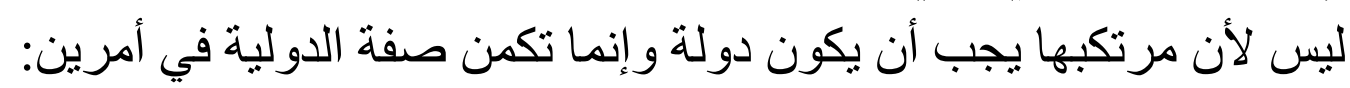

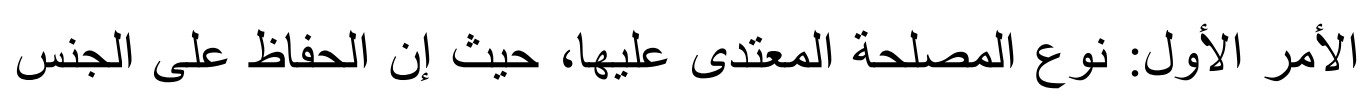
البشري والإبقاء على مصالحه وحقه في استمراره في الحياة والبقاء بلا تمبيز

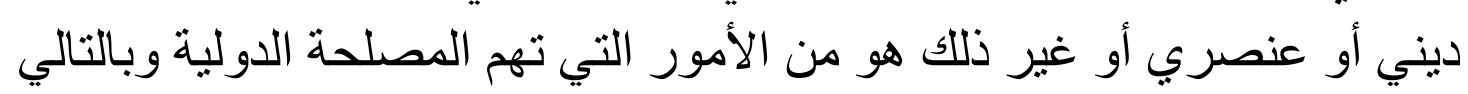
تستمد حمايتها من المجتمع الدولي.

الأمر الثاني: إن هذه الجريمة هي مجرمة في كل قوانين الثُعوب وبالتالي

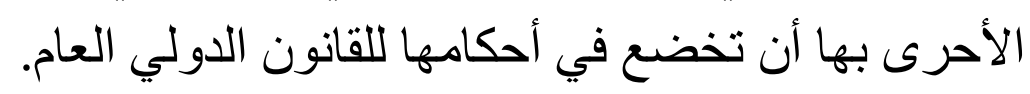

وحددت الاتفاقية فى المادة الثالثة الأفعال المكونة لجريمة الإبادة الجماعية،

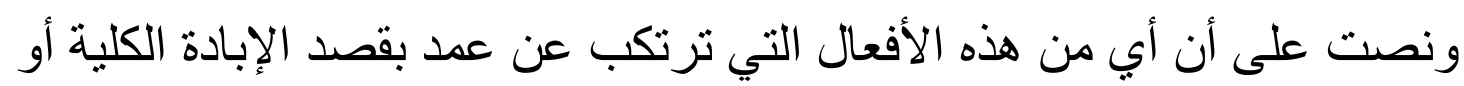
الجزئية لجماعة وطنية، أو عرقية، أو عنصرية، أو دينية. و على رأس أس هذه الأفعال

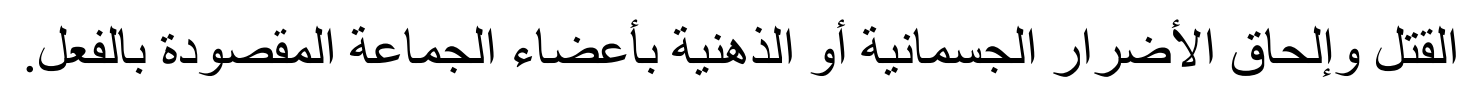

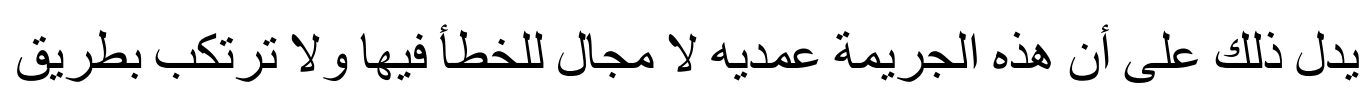

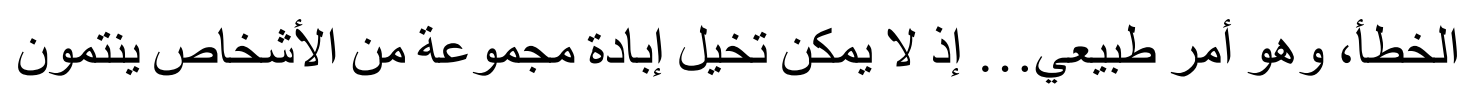
لجماعة و احدة - أياً كان نو عهاً: ويحتج بالخطأ. 
فمثلاً: القنابل النووية لم تسقط سهواً أو خطاً علي جزيرتي هيروشيما

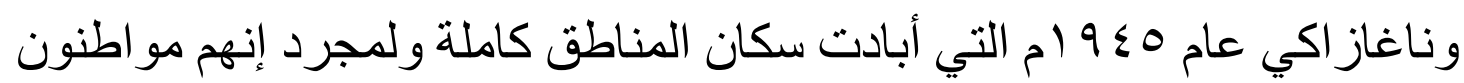

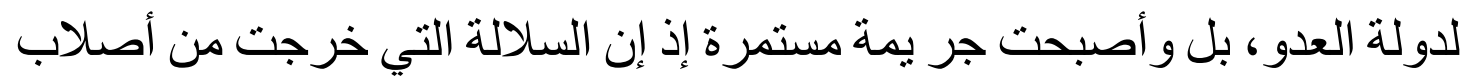

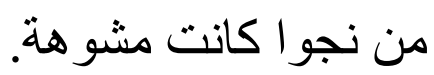

اولاً: صور جريمة الابادة الجماعية

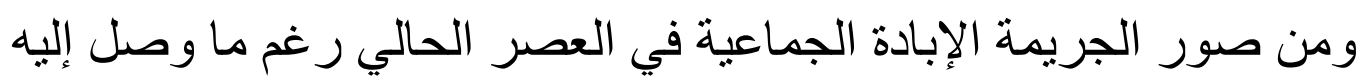

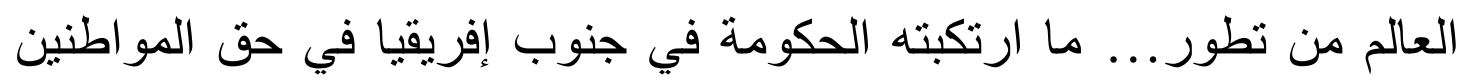

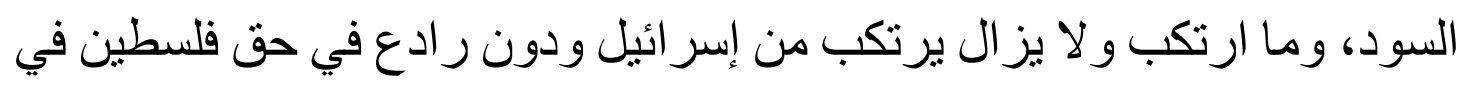
الأر اضي المحتلة، ولبنان و غير ها.

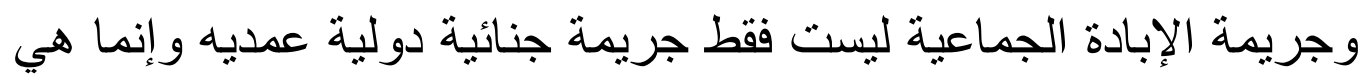

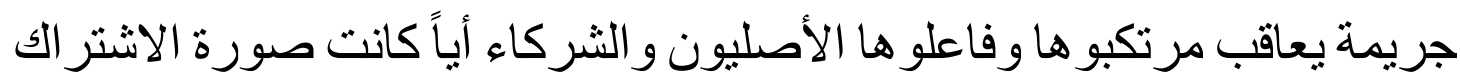

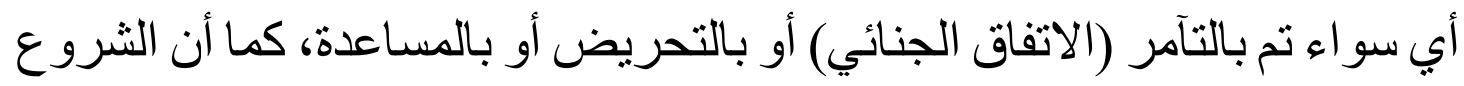

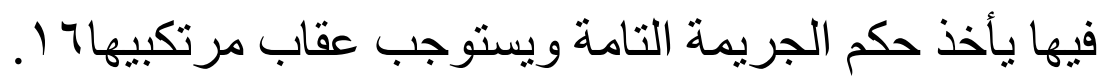
و اقتصرت الاتفاقية عن بيان نوع العقوبة التي توقع على مرتكبي جريمة

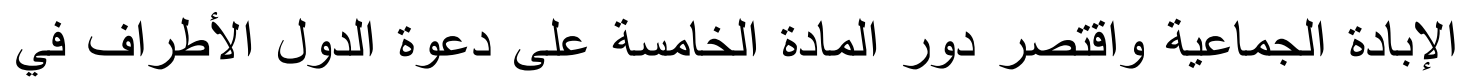

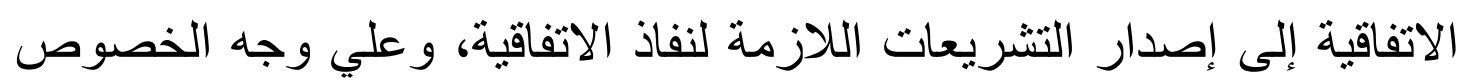

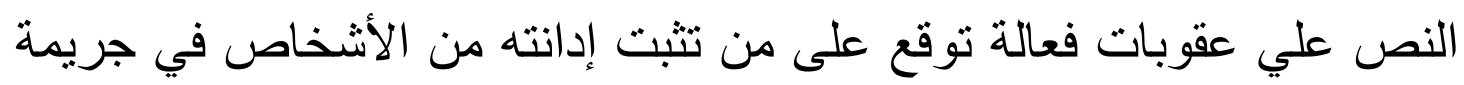

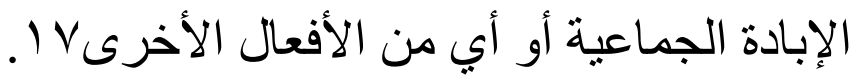

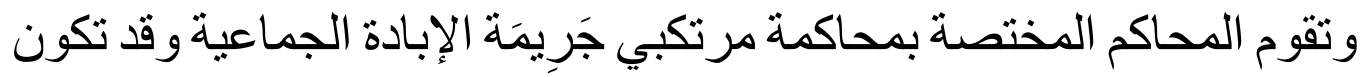

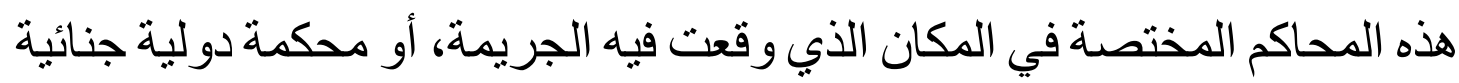

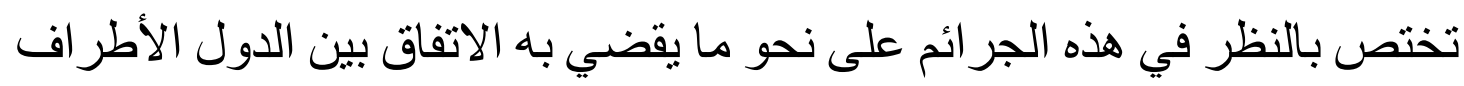

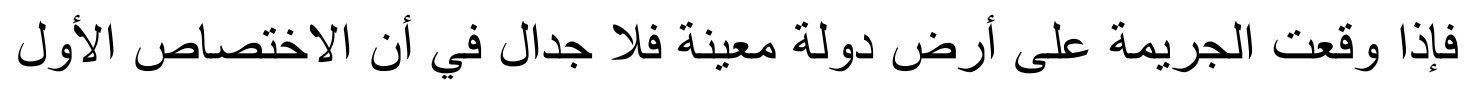

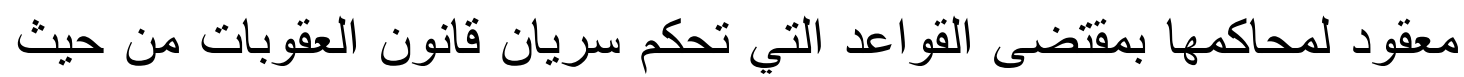

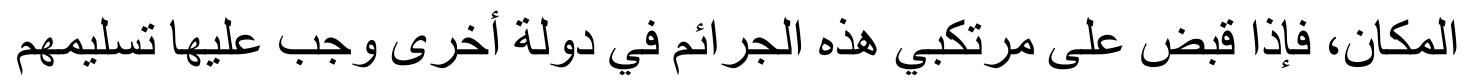

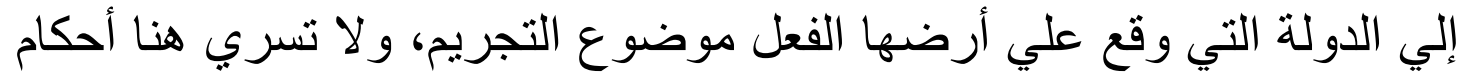

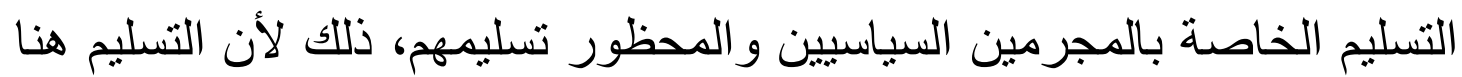

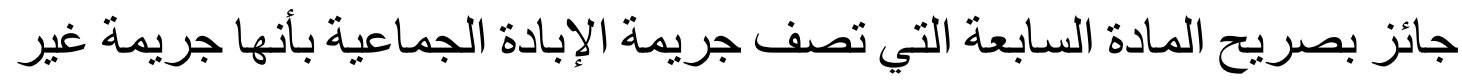


ولما كان تسليم المجرمين العاديين تحكمه قو اعد و اتفاقيات معينة، فالر اجح

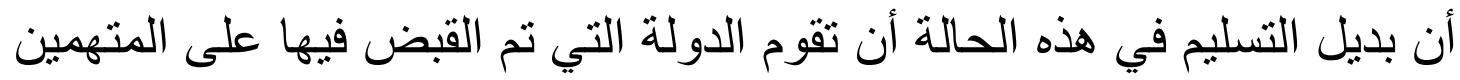
بارتكاب هذه الجريمة بمحاكمتهم أمام محاكمها المختصة.

فإذا تم استبعاد محاكمتهم أمام محاكم الدولة التي وقع على أرضها الفعل الفعل

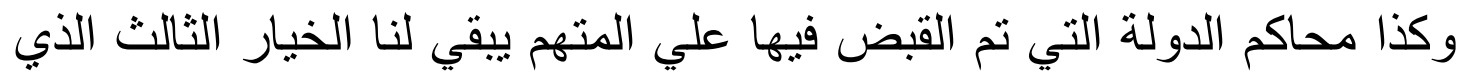
اعترفت به المادة السادسة من الاتفاقية... و هو مبدأ القضاء الدولي الجنائي.

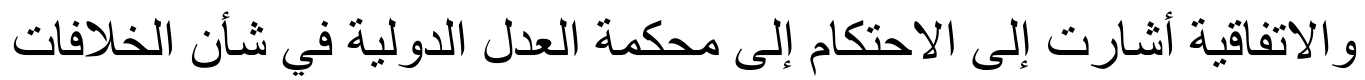

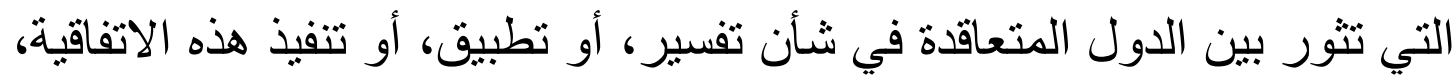

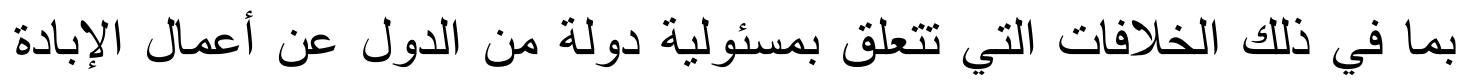
الجماعية أو ما يتصل بها من أعمال.

و إذا ما انطوت جريمة الإبادة الجماعية على فعل يشكل مسئولية دولية لدولة المانة

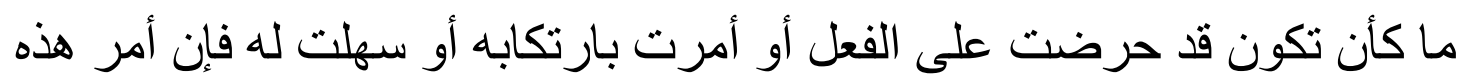

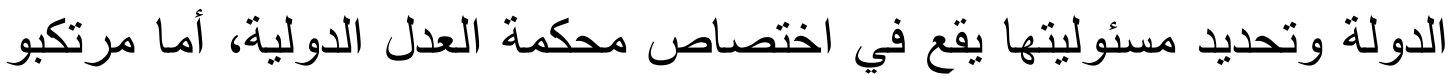

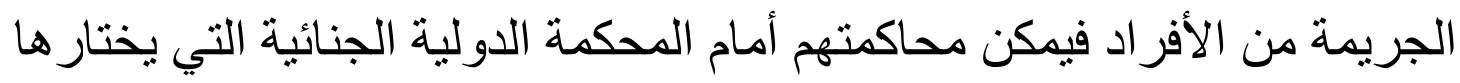

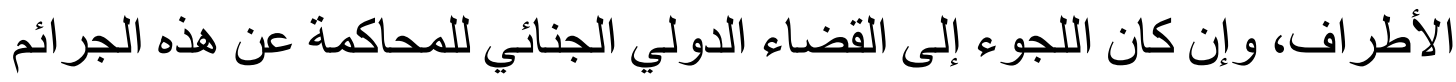

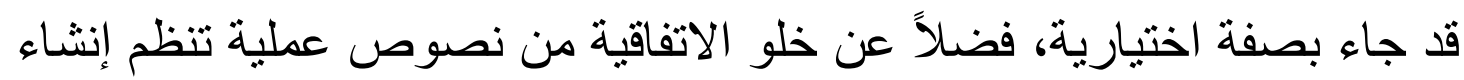
هذا النوع. و عليه فإن هذه الجريمة لا دافع من ور ائها إلا أهو اء شخصية وكر اهية وحقد

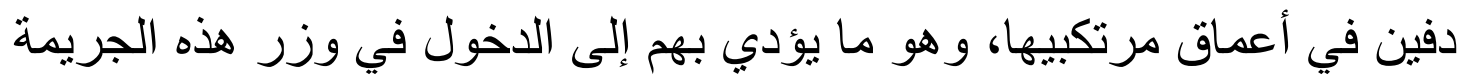

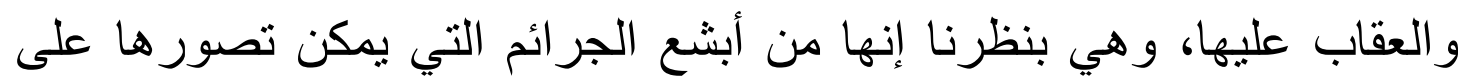

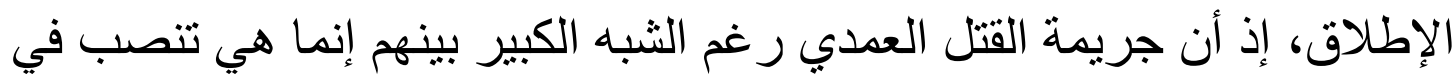

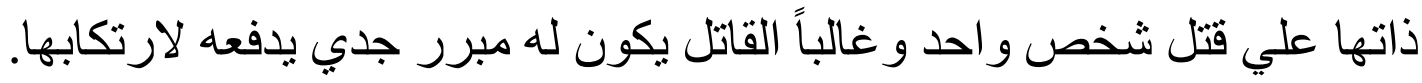
أما جريمة الإبادة الجماعية فالقاتل قد يكون فيها واحداً أو أكثر ولكن المجني

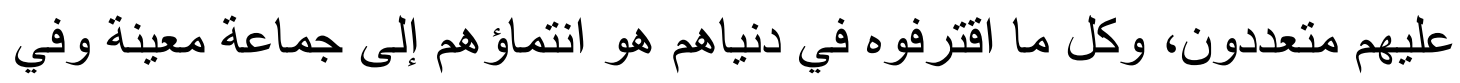

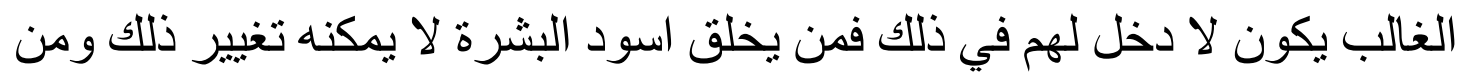

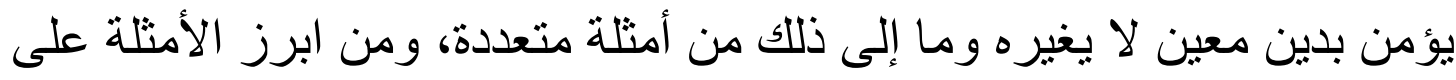

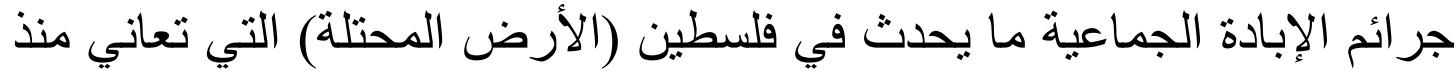

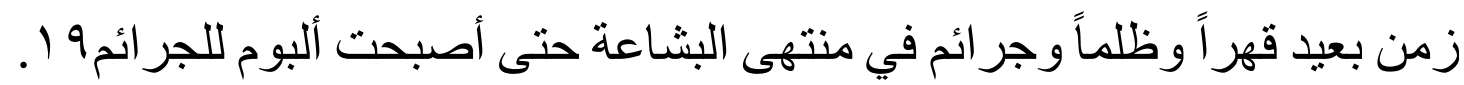


إن الو اقع؟، بعد إقرار نظام المحكمة الجنائية الدولية ـ في مؤتمر روما عام

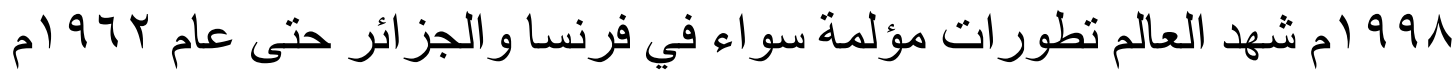
ثم حرب رواندا، وحرب كوسوفا والبوسنة والهرسك، والصراع العاء العربي

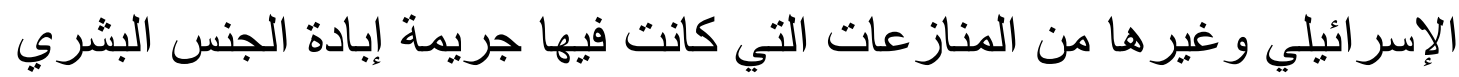

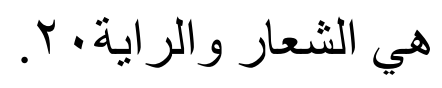

علامات جريمة الإبادة الجماعية

و السؤ ال الذي يمكن طرحه ماهى العلامات إلى يمكن صياغتها لتكون إنذارًا

بحدوث إبادة جماعية؟

أجاب المستشار الخاص المعني بمنع الإبادة الجماعية بقائمة علامات تشير إلى تعرض مجتمع من المجتمعات لخطر الإبادة الجماعية أو الفظائع المشابهة.

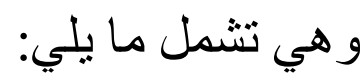

ا ـأن تكون للبلد حكومة شمولية أو قمعية لا تقبض على زمام السلطة فيها إلا فئة و احدة.

r-أن يكون البلد في حرب أو أن تسوده بيئة من عدم احترام القوانين يمكن أن

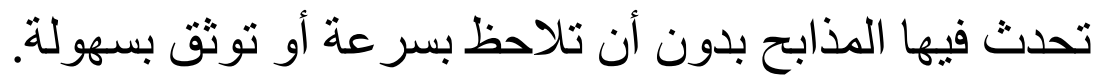

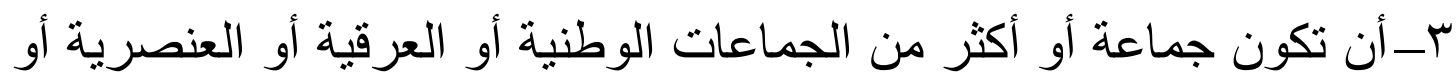

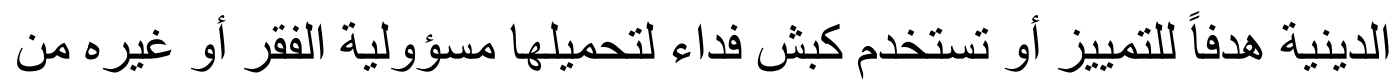
المشناكل الاجتماعية التي تو اجه البلد حاليا.

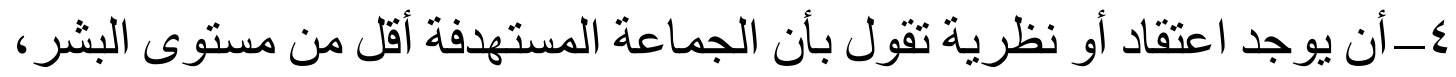

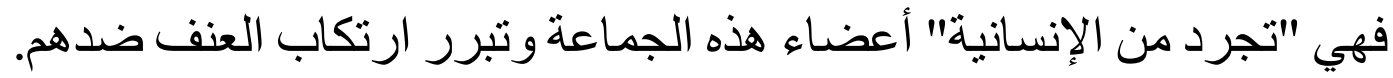

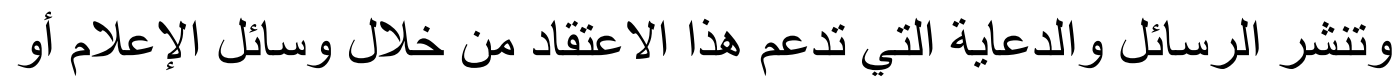
في التجمعات (تجمعات الكر اهية) ورسائل الكر اهية. ○_أن يوجد قبول متزايد للانتهاكات المرتكبة ضد حقوق الإنسان للجماعة

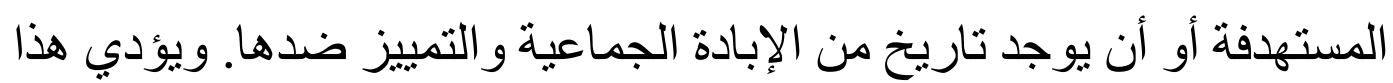
إلى الاعتقاد بأنه إذا أفلت الآخرون بارنتابن من الإبادة الإبادة الجماعية في الماضي،

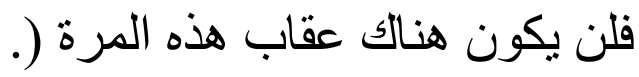
ثانياً: اشكال جريمة الإبادة الجماعية 
نثير في البداية إلى أبرز أركان جريمة الإبادة الجماعية والتي نوردها في

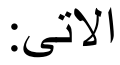

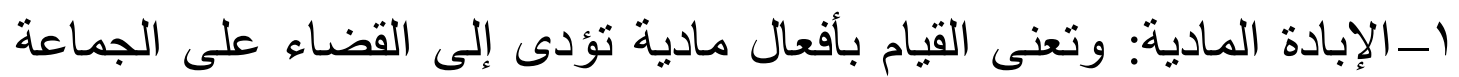

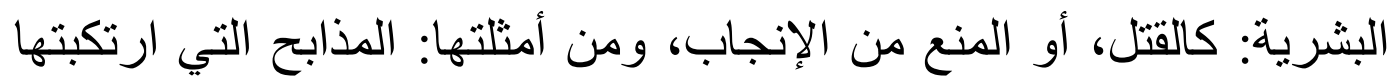

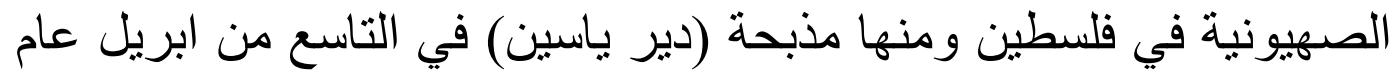

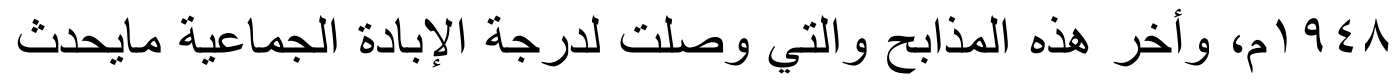

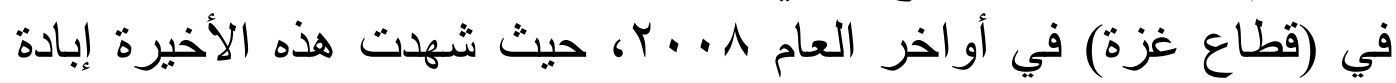

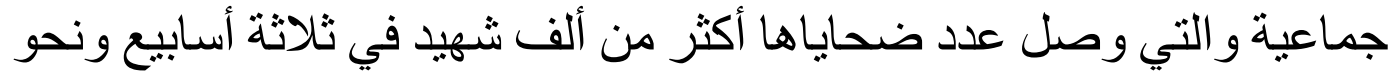

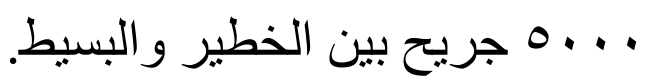

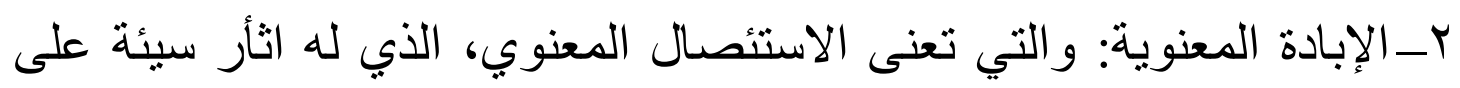

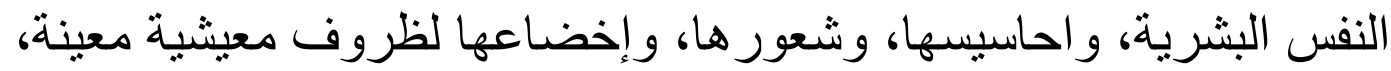

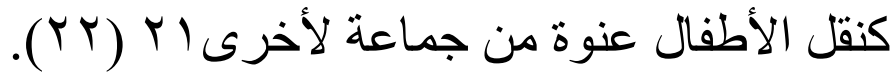
ويمكن شرح تللك الصور فيما يأتي:

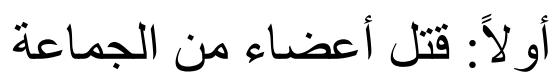

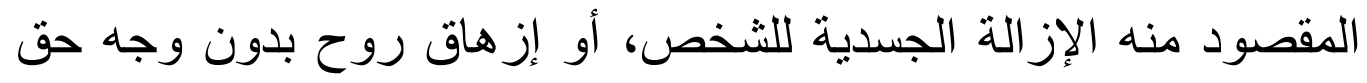

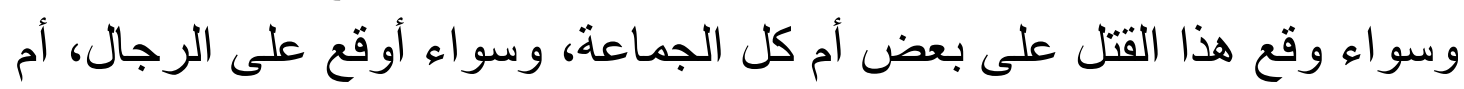

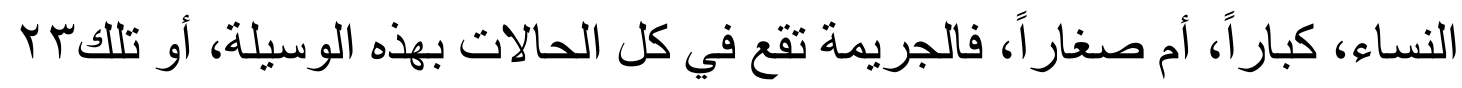

ومثال ذلك: قتل أعضاء من الجماعة لا حصر لها، ومن الأمثلة عليها ما

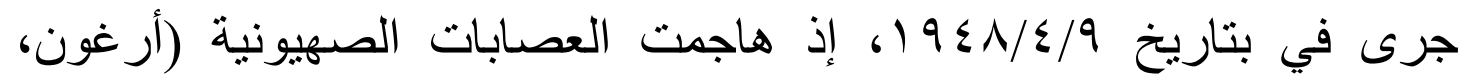

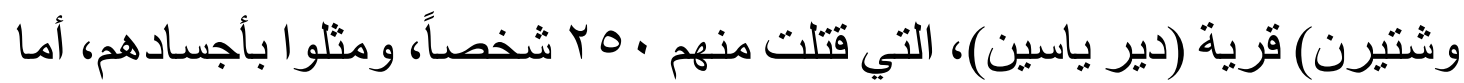

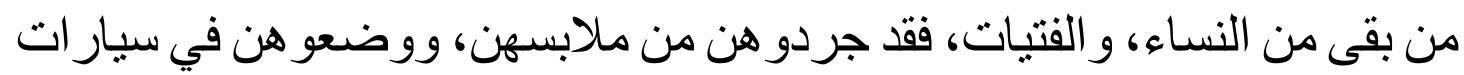
مكثوفة، وطافو ا بهن في شوارع القدر حيث تعرضن لسخرية اليهود، و الاعتداء

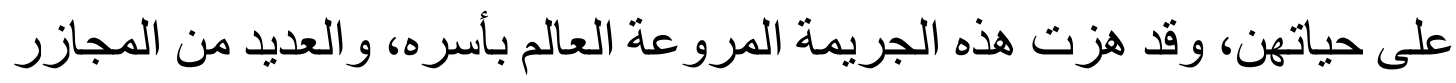

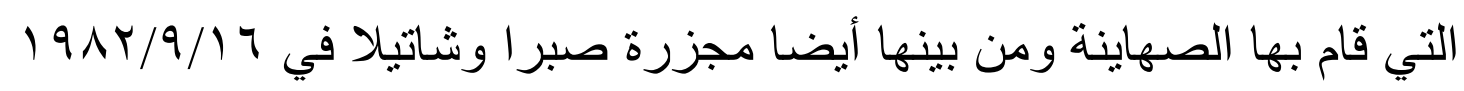

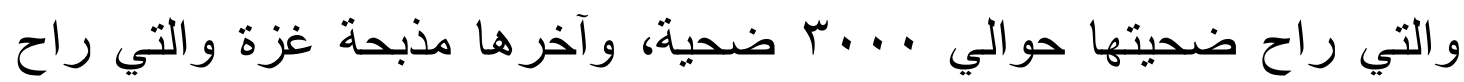

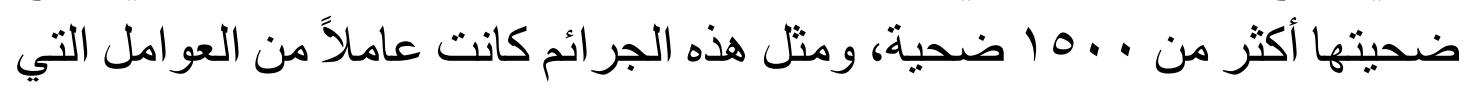
أدّت إلى هجرة جزء كبير من سكان فلسطين. 
ثانياً: إخضاع الجماعة عمداً لظروف معيشية بقصد إهلاكها الفعلي كلياً أو جزئياً

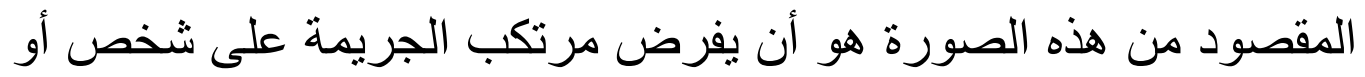
أكثر من أفراد الجماعة أحو الاً معيشية معينة، بقصد إهلاكها كليا أو جزئياهب.

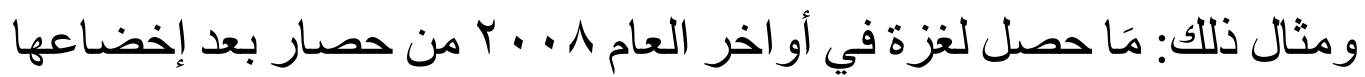

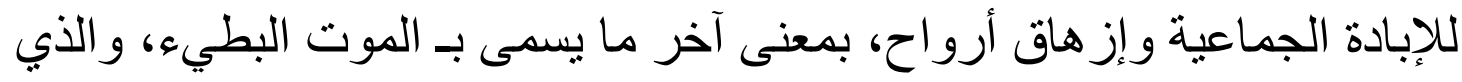

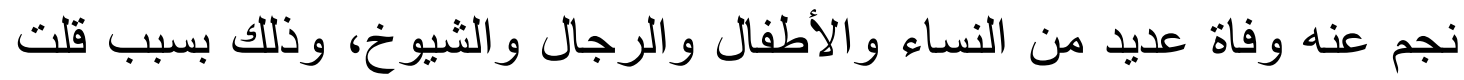

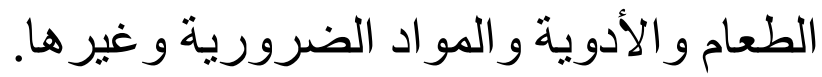
ثالثاً: إلحاق أذى جسدي أو روحي خطير و المقصود بذللك المساس بالسلامة الجسدية وهي شكل من أنثكال الضرر

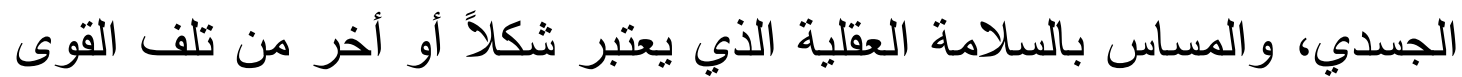

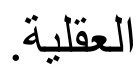

و المساس ليس فقط إزهاق روح فرد أو التسبب في ذللك، ولكن قد يكون

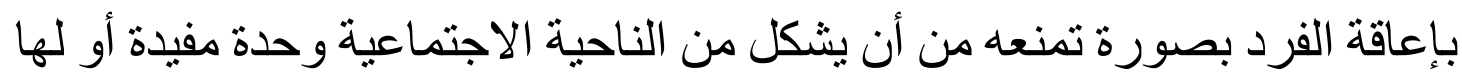

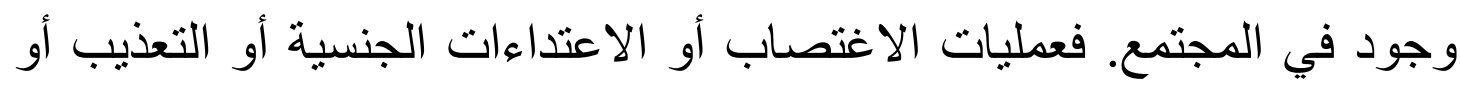

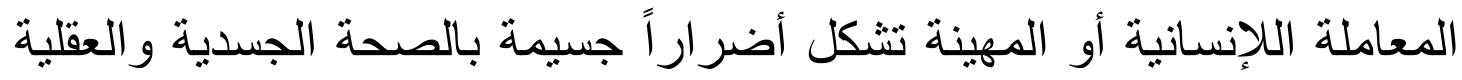

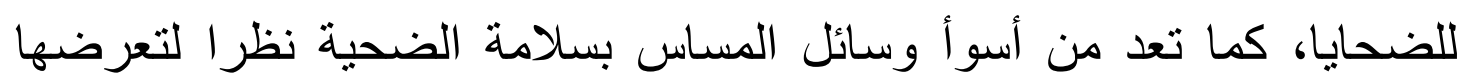

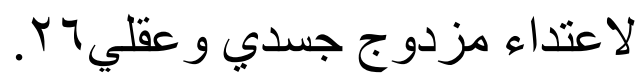
رابعاً: فرض تدابير تنتهدف منع الإنجاب وهى وسيلة تعتمد على أساليب بيولوجية تعيق النيابن النمو، وتكاثر أعضاء الجماعة المستهدفة، لاسيما بالتحريض على على الإجهاض، و العقم، وفصل البهل البالغين

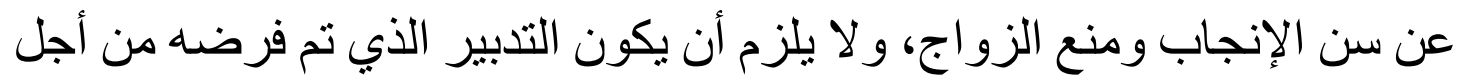

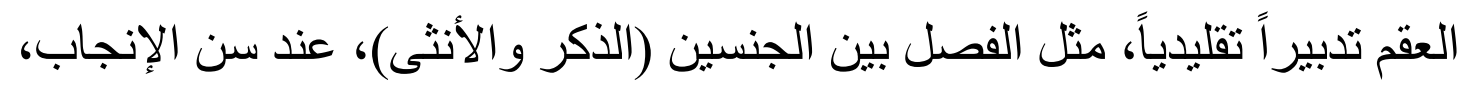

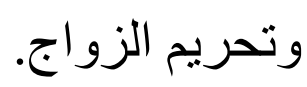

ومثال ذللك: ماقامت به القوات الصربية في (البوسنة والهرسك) بخصي الرجال؛ لمنع الإنجاب لاى المسلمين هناك. و الأمتلة كثيرة.

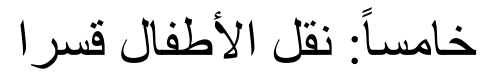
يعتبر الأطفال أكثر الفئات تضررا في النزاعات المسلحة، ويكون النقل بهدف فصلهم عن جماعتهم الأصلية حتى يفقدو ا جذور هم. 
ويعتبر النقل القسري صورة من صور جريمة الإبادة الجماعية، الذي

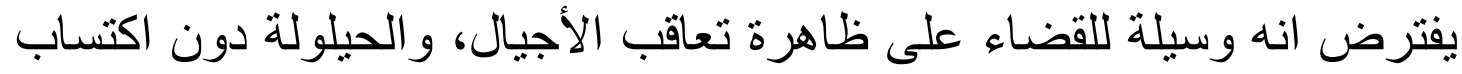

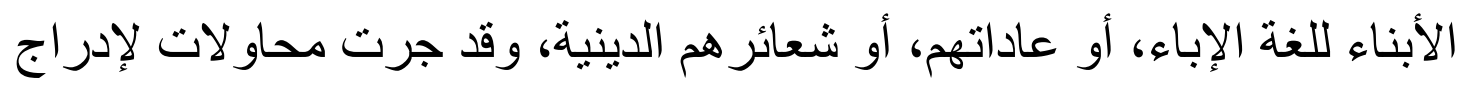

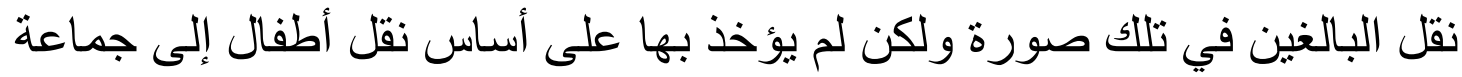

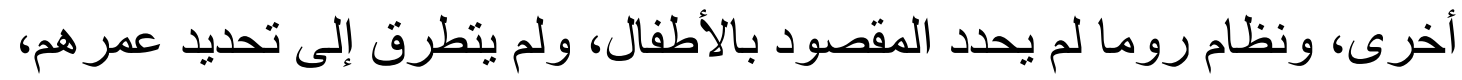
ويشترط لوقوع تلك الجريمة نو افر الأركان التالية:

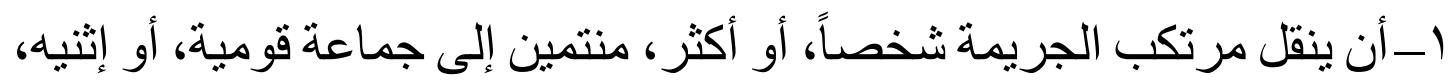

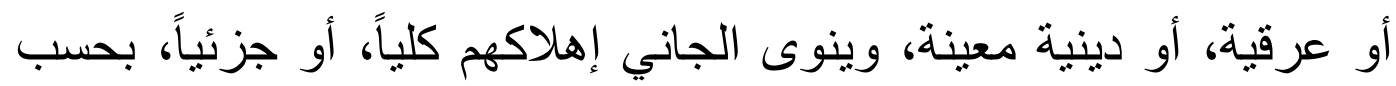
صفتهم.

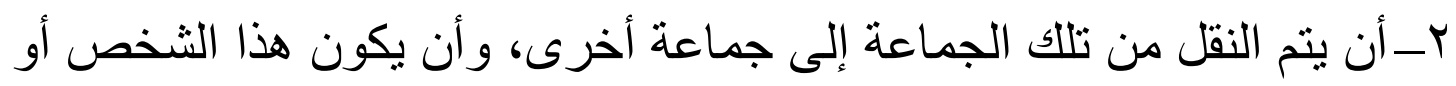

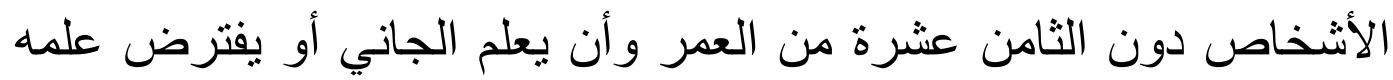

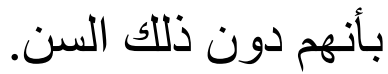

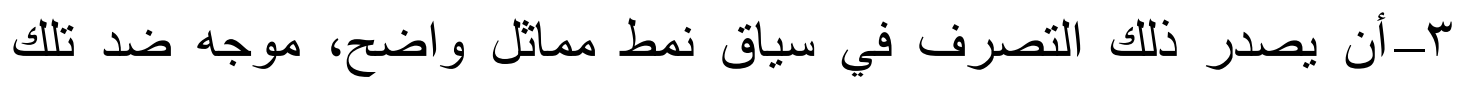

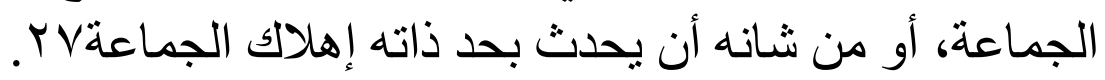

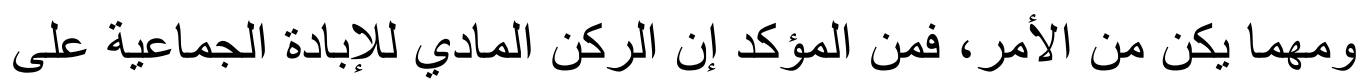

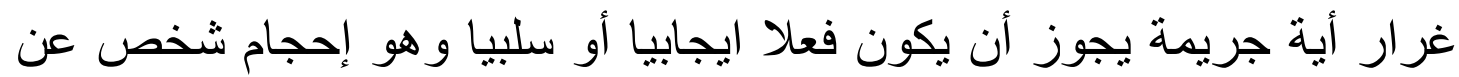

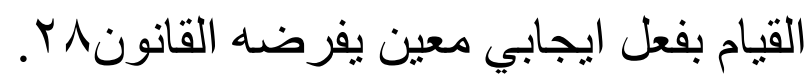

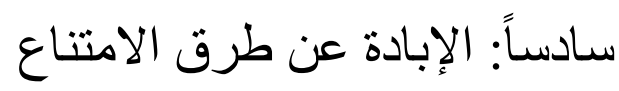
يقع الفعل الإيجابي بواسطة عدأ الإنداع معين من التصرفات تم تعدادها بصورة

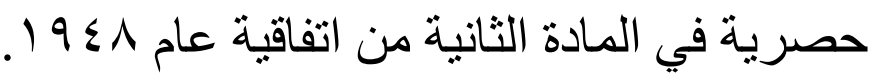

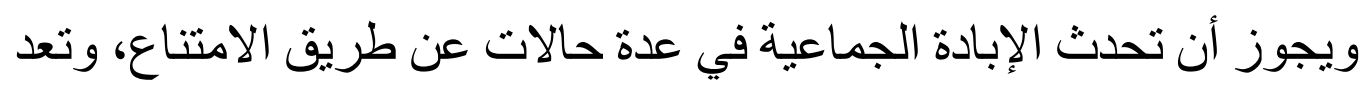

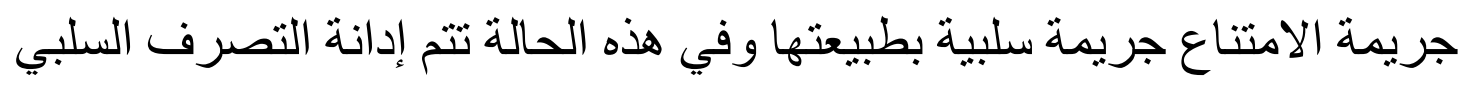

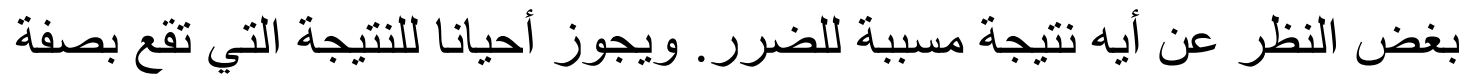

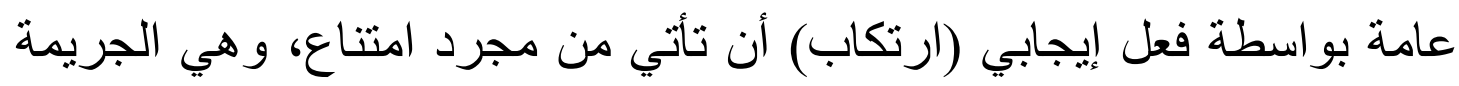
التي يطلق عليها " ارتكاب عن طريق الامتناع و الجر ائم السلبية ذات النتيجة.

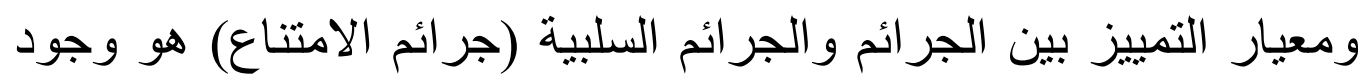

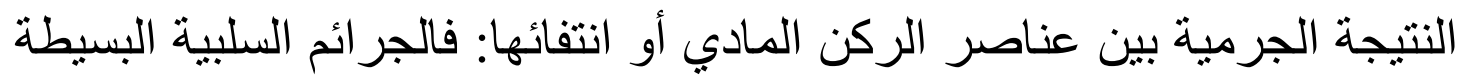

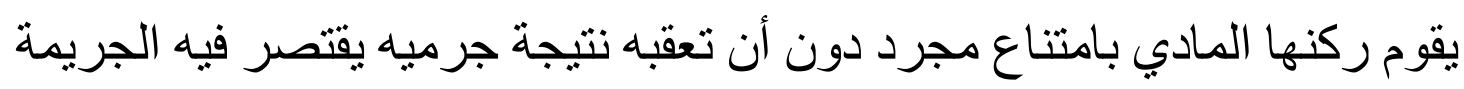


على الإثارة إلى الامتتاع فيقرر العقاب من اجله وتعتبر الجريمة تامة به ولا لإنها

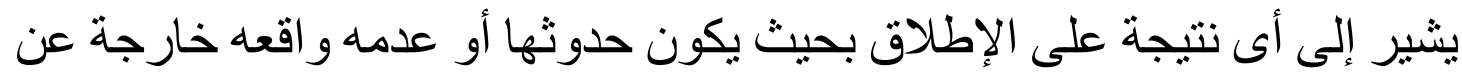

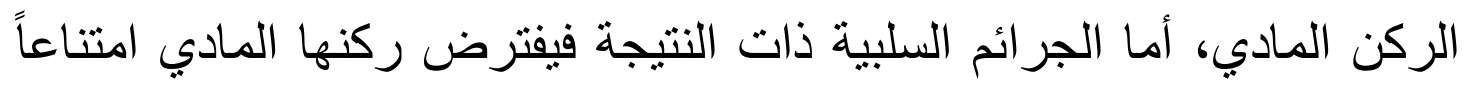

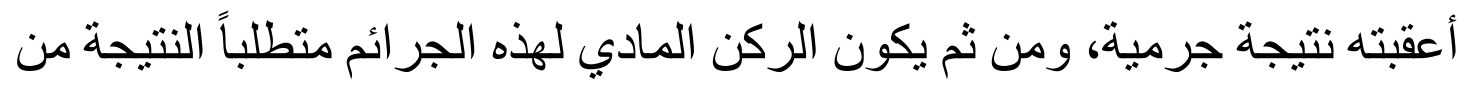

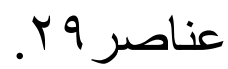

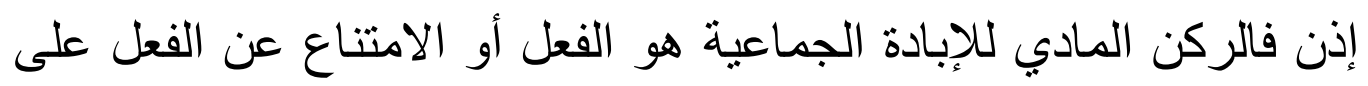

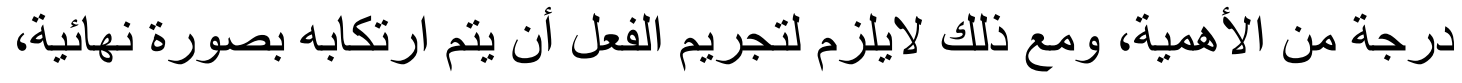

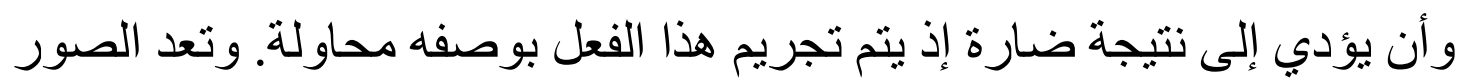
التي تم تبيانها من أهم صور الإبادة الجماعية.

\section{المبحث الثاني}

\section{اتفاقية منع جريمة الإبادة الجماعية والعقاب عليها}

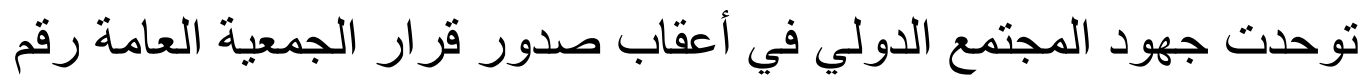

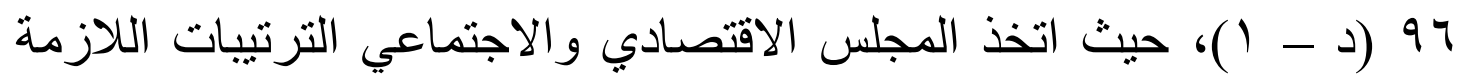

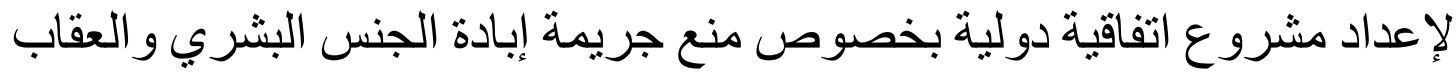

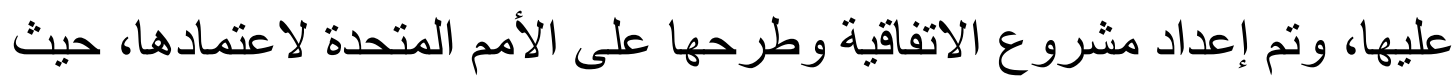

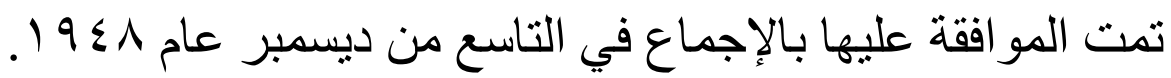

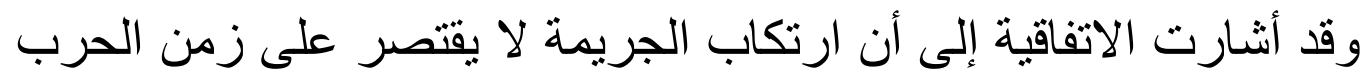

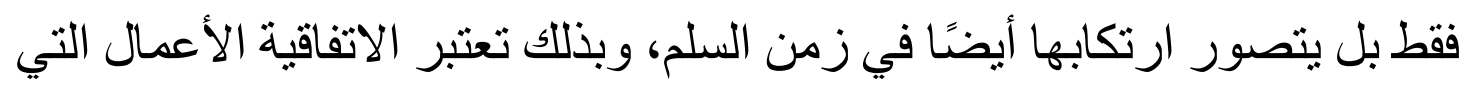

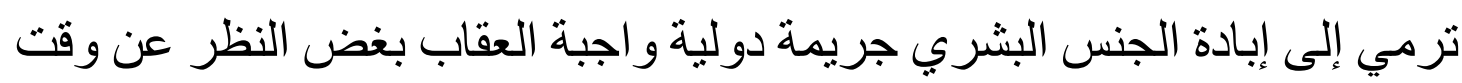

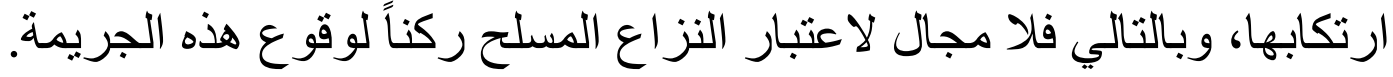
وقد عرفت المادة الثانية من الاتفاقية جريمة إبادة الجنس البشري بأنها تعني

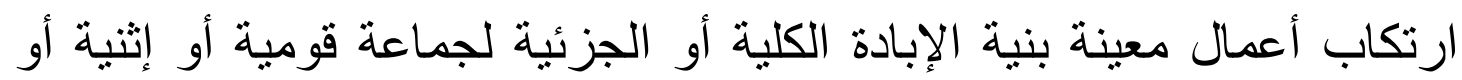
عنصرية أو دينية. r. ثم حددت تللك المادة بعض صور الأفعال التي يتحقق بها الركن المادي

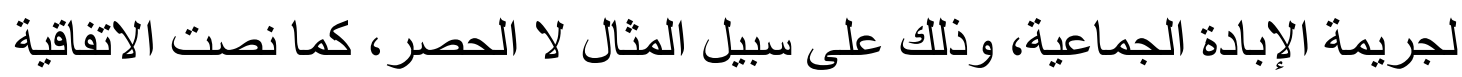
على خمس صور للسلوك الإجر امي المؤثم لجريمة الإبادة الجماعية، وهي: 
إبادة الجنس البثري.

الاتفاق أو التآمر على ارتكاب جريمة إبادة الجنس.

التحريض المباثر والعلني على ارتكاب جريمة إبادة الجنس.

$$
\text { الثروع في ارتكاب جريمة إبادة الجنس. }
$$

الاشتر اك في ارتكاب جريمة إبادة الجنس البشري.

وجدير بالذكر أن كل صورة من الصور السابقة تعد بمفردها جريمة مستقلة

قائمة بذاتها وو اجبة العقاب.

ويتحقق الركن المعنوي في هذه الجريمة حال تو افر القصد الجنائي، وهو ما

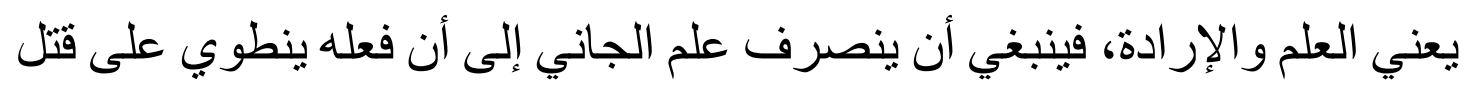
أو إيذاء أو تدمير أو قهر لجماعة معينة أو نسلها، كما ينبغي أن تتصرف لإف الإز ادة إلى ذلك.

إلا أن القصد الجنائي العام لا يكفي هنا فقط لتحقيق الركن المعنوي، وإنما

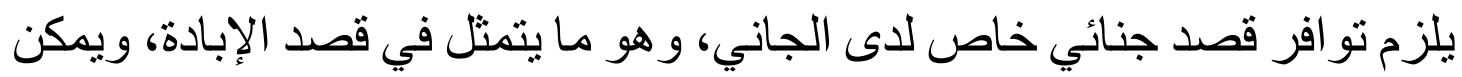

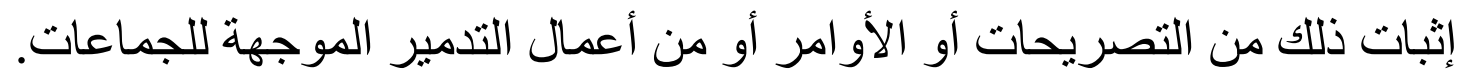
أما عن الركن الدولي في تلك الجريمة فيشترط أن بتم ارتكابها بناء على ملى دراء خطة مرسومة من جانب دولة ضد دولة أخرى، وقد تصدرت المادة الر ابعة من فئن الاتفاقية إمكان ارتكاب الجريمة بناء على تشجيع الطبقة أو الفئة الحاكمة في الدولة المرتكبة للجريمة.

أما عن المسئولية الجنائية في تلك الجريمة فقد أثنارت الاتفاقية إلى التزام

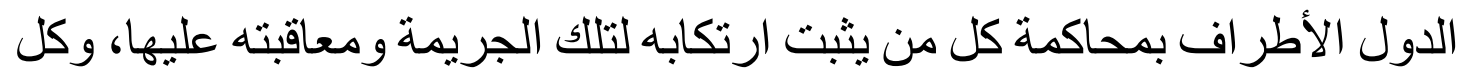

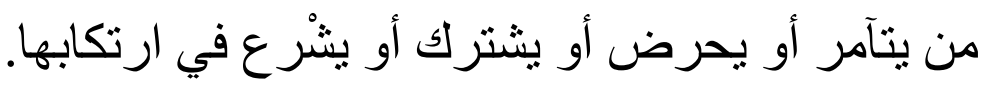
أصدرت الجمعية العامة للأمم المتحدة قرار هار رقم 97 (د - ( ) في الحادي

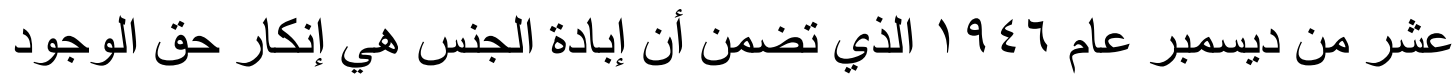

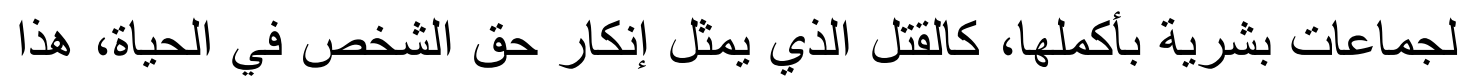

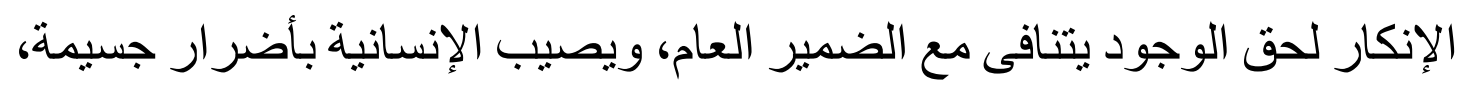

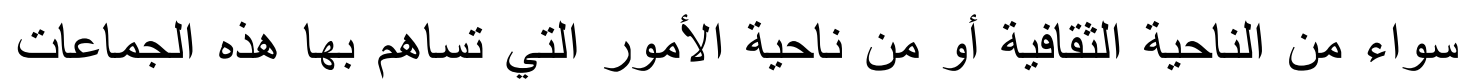
البشرية، الأمر الذي لا يتفق والقانون الأخلاقي وروح ومقاصد الأدو الأمم المتحدة، 
ولما كانت قد وجدت أمثلة كثيرة لجر ائم إبادة الجنس، إذ أبيدت ـ كليًا أو جزئيًا جماعات بشرية لصفتها العنصرية أو الدينية أو السياسية أو غيرهان أنها، ولما كانت

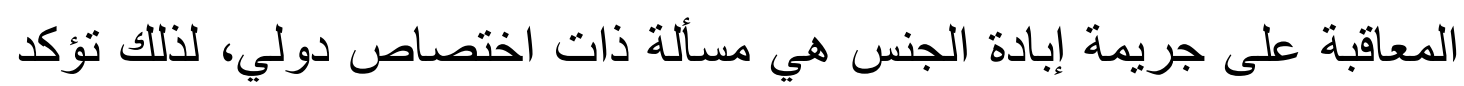

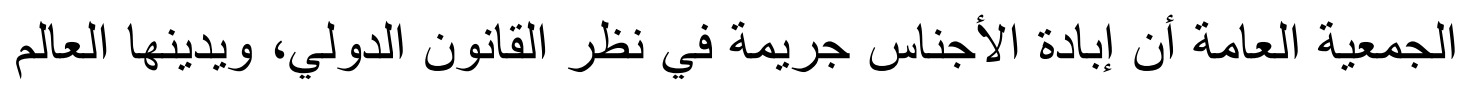

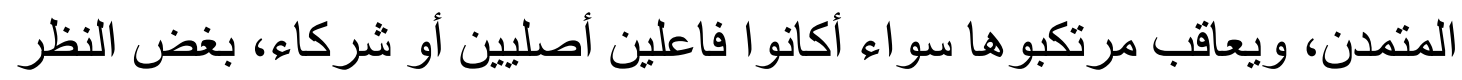

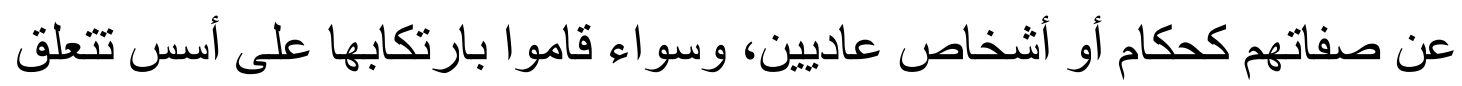
بالدين أو السياسة أو الجنس أو أب شيء آخر. كذلك تدعو الجمعية العامة للأمم

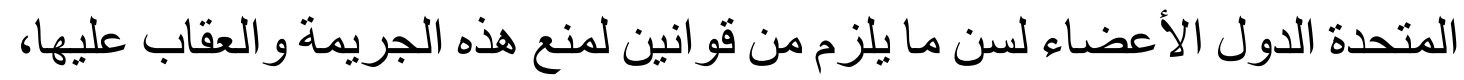

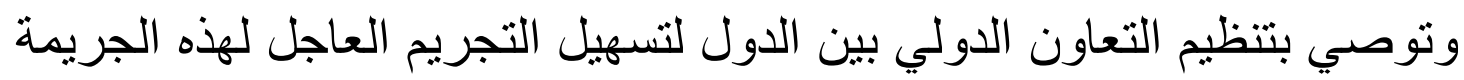

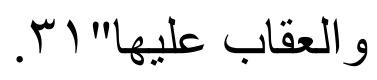

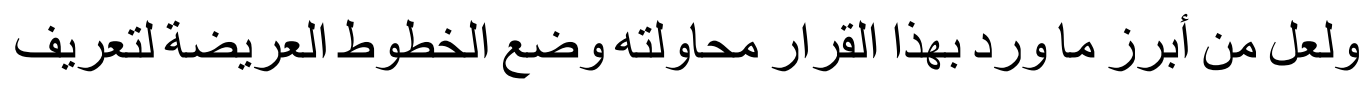

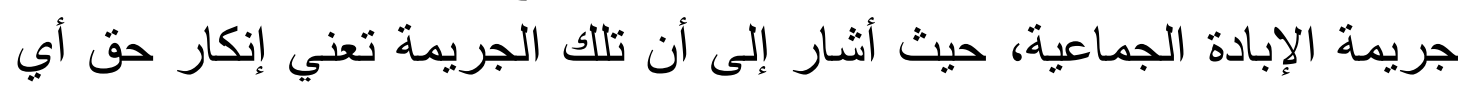

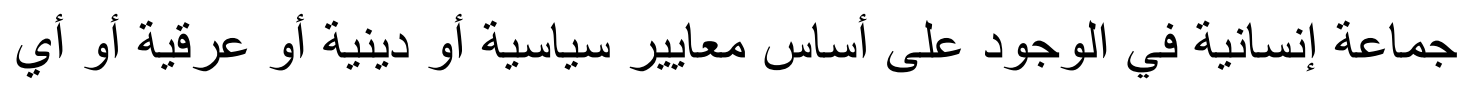

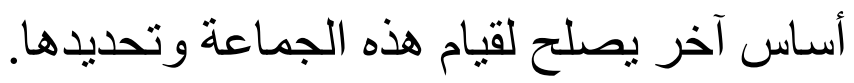

ويعزى إلى هذا القرار أيضًا أنه اعتبر إبادة الجنس البشري جريمة دولية

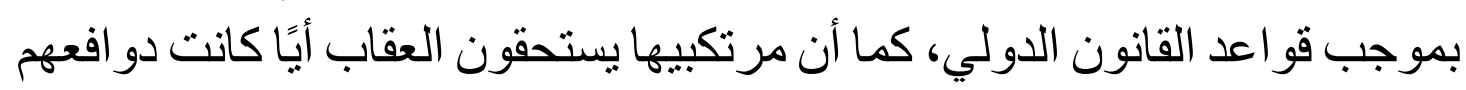

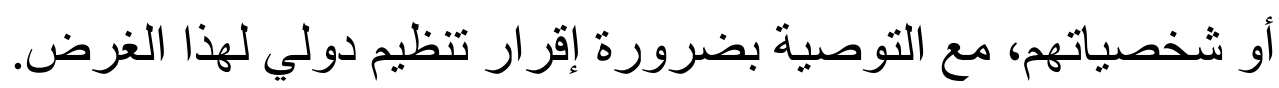

\section{المطلب الأول}

\section{تحديد الجماعات المحمبة بمقتضى الاتفاقية}

تحمي الاتفاقية أربع جماعات، وهي: الجماعات القومية أو الإثنية أو أو أوبات

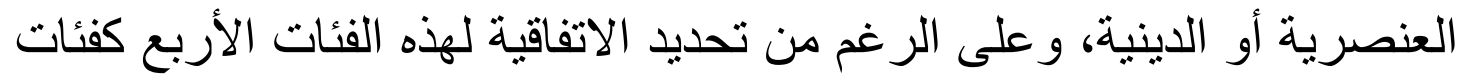
محمية بموجب الاتفاقية، إلا إن بعض الدول قد حاولت من الت التوسع في تلك الفئات

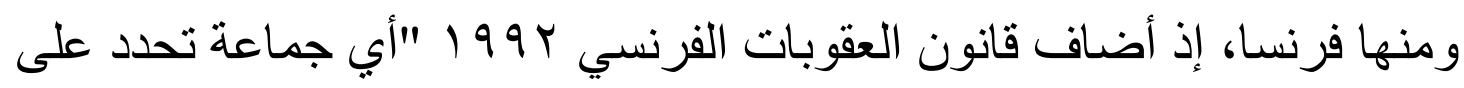
معايير عثوائية".

وتجدر الإشارة إلى أن الأعمال التحضيرية لهذه الاتفاقية قد ورد فيها ذكر الجماعات السياسية والاقتصادية كجماعات محمية بموجب هذه الاتفاقية، إلا أنه تم التغاضي عنها بحجة عدم تمتعهم بالثبات، وبالتالي عدم القدرة على تحديد 
أفر ادهم، حيث إن لأفر اد هذه الجماعات حرية الاختيار في الانضمام و العضوية

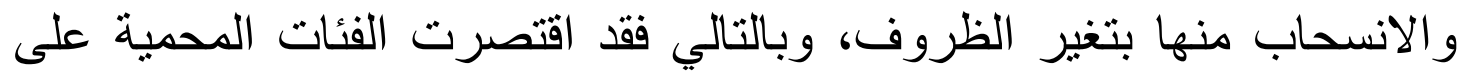
الجماعات السابقة التي تكون العضوية فيها للأفر اد بصفة دائمة وتحدد بالو لادة.

$$
\text { دور المحاكم الدولية في التصدي لجريمة الثاني }
$$

كان للمحاكم الدولية دور هام في التصدي لجريمة الإبادة الجماعية وقد ظهر ذللك من خلال محكمة جرائم الحرب في يوغوسابلافيا السابقة ومحكمة جرائم الحرب في رواندا، و أخيرًا في النظام الأساسي للمحكمة الجنائية الدولية الدائمة في روما، وذللك على النحو التالي:

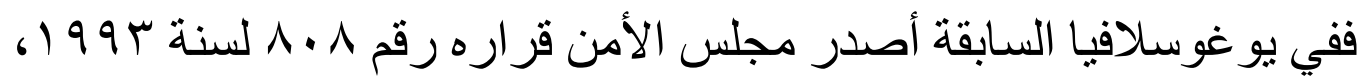
وضمن فقرته الأولى قرار المجلس بإنشاء محكمة دولية من أجل مقاضاة

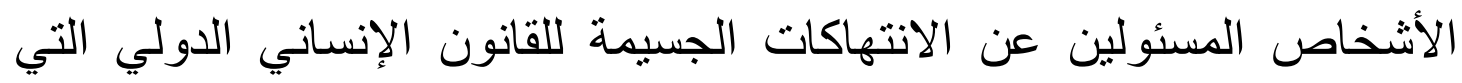

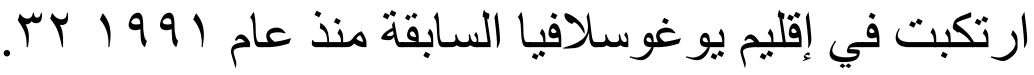

وقد نص في النظام الأساسي للمحكمة الدولية بيوغوسلافيا السابقة على الى الئ اختصاص المحكمة بالعقاب على جريمة إبادة الأجناس، وعدَّد التقرير الأفعال

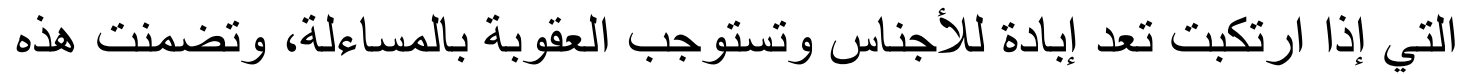

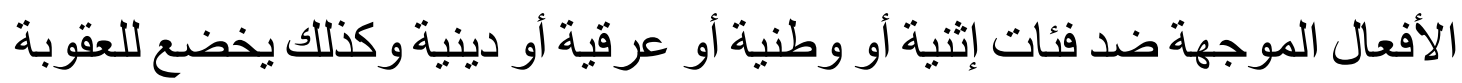

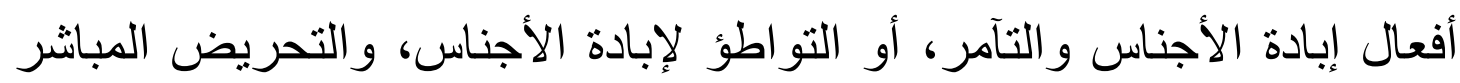

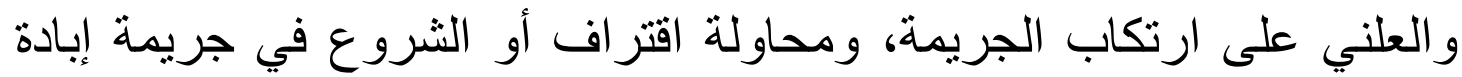
الأجناس، و الاشتر الك في جريمة إبادة الأجناس.

أما في رو اندا فقد أصدر مجلس الأمن قراره رقم 900 لسنة ؟9 99 (، بإنشاء محكمة جنائية دولية لرواندا و على نهج النظام الأساسي ذاته للمحكمة الجنائية

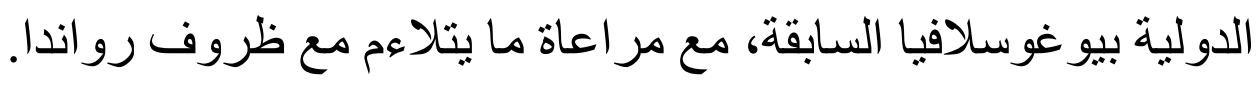
وقد نص النظام الأساسي للمحكمة الجنائية الدولية برو اندا على اختصاص

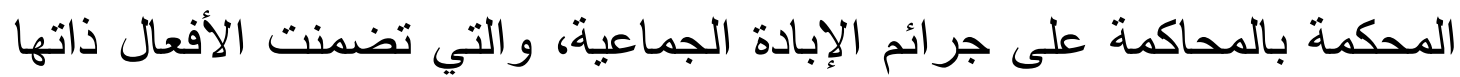


و الصور المكونة للجريمة كما هو وارد بالمحكمة الجنائية الدولية بيو غوسلافيا السابقة.

وقد نهجت المحكمة الجنائية الدولية عام 991 النهج ذاته في تجريم الجرائم الأشد خطورة على المجتمع الدولي بأسره، ومن بينها جريمة الإبادة الجماعية، فقد تضمن النظام الأساسي للمحكمة الاختصاص بمحاكمة مرتكبي جريمة الإبادة

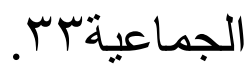

\section{المطلب الثالث}

$$
\text { نماذج لجر ائم إبادة الجنس }
$$

في يو غوسلافيا وفي مدينة هامبارين المسلمة، تم إبادة ألف شخص في الفترة

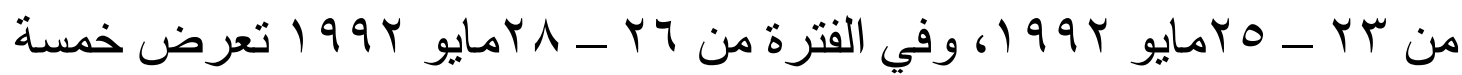
آلاف شخص من قرية كوزار الك المسلمة إلى الإعدام بلا محاكمة، وفي مدينة فيثكر اد قام الصرب بقصف المدينة بالمدافع ثم ذبح أئمة المساجد و التمثيل بجثنه الإنه

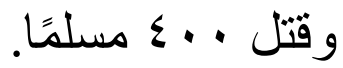

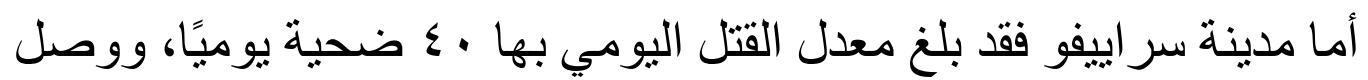

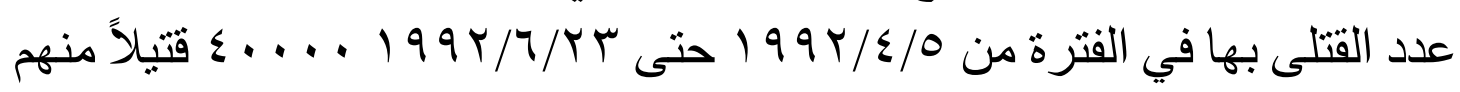

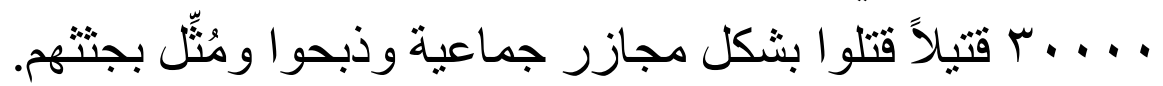

وفي فلسطين ارتكبت السلطات الإسرائيلية عمليات إبادة جماعية للثعب

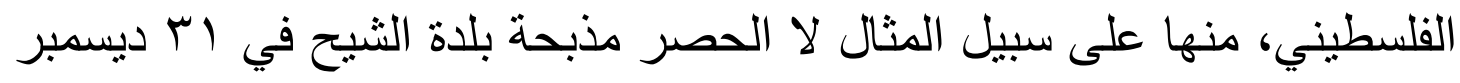

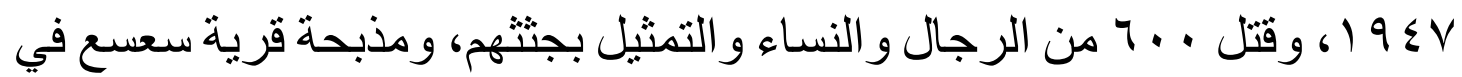

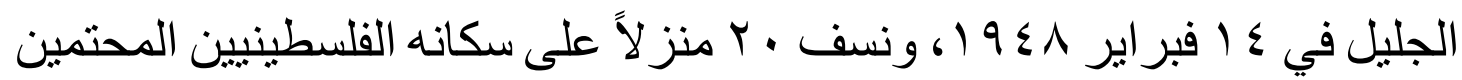

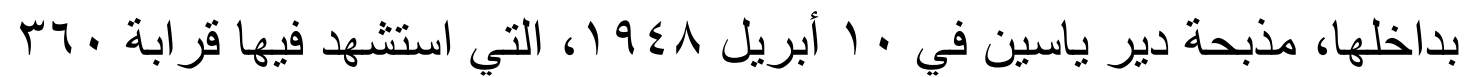

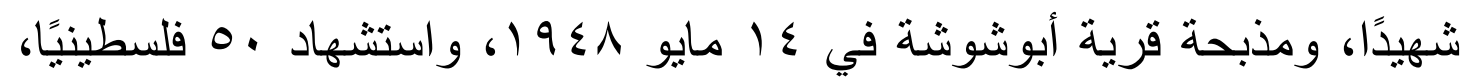

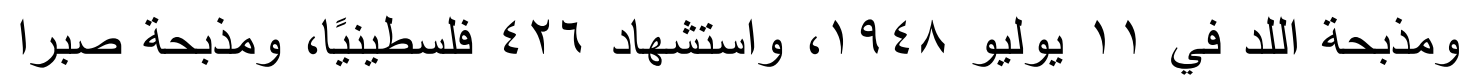

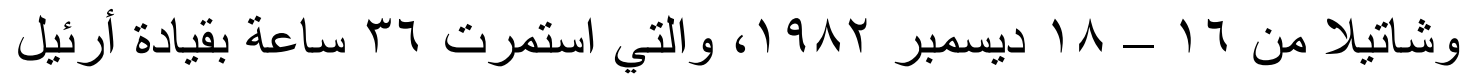

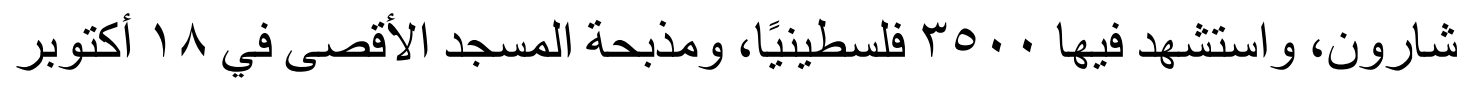

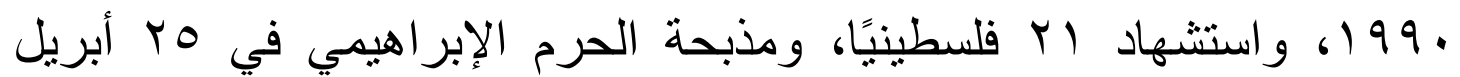

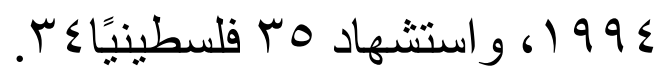




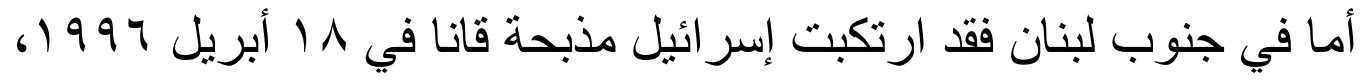

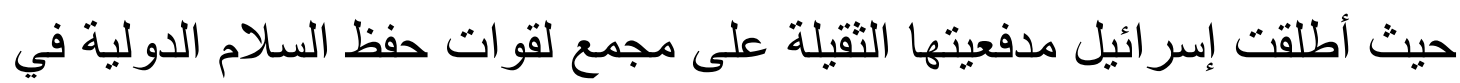
جنوب لبنان، الذي كان يحتمي به مئات الأشخاص من المدنيين الفلسطينيين و اللبنانيين، وكانت الحصيلة ـ ـ 17 شهيدًا.

\section{المبحث الثالث

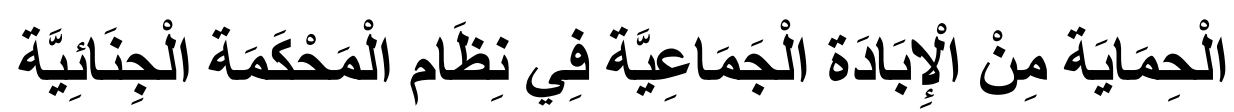 الآَّْْلِيَّة}

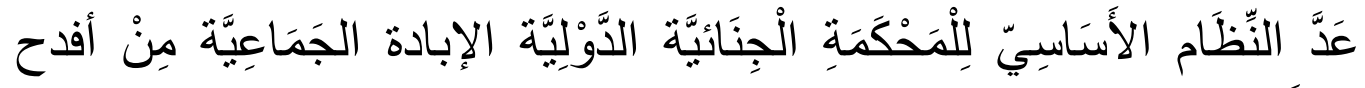

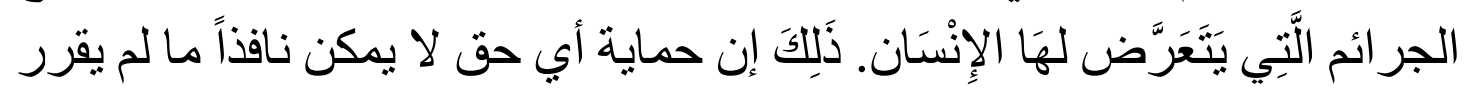

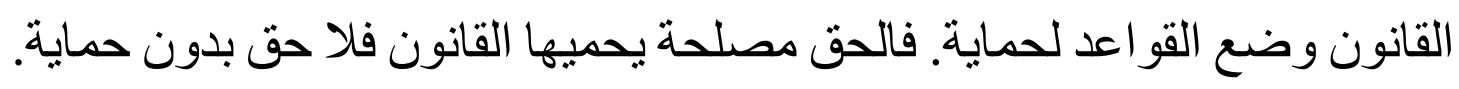
وقد نص نظام روما الأساسي للمحكمة الجنائية الدولية لعام 991 19، على حماية لاعناية

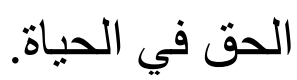

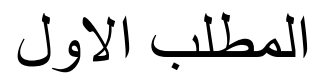

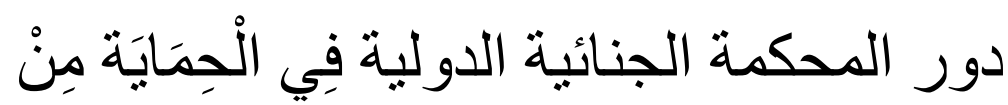
الإبادة الجماعية

أوردت المادة الخامسة من نظام روما الأساسي للمحكمة الجنائية الدولية 1991 جريمة الإبادة الجماعية في المرتبة الأولى من الجر الائم الدولية الجنائية.

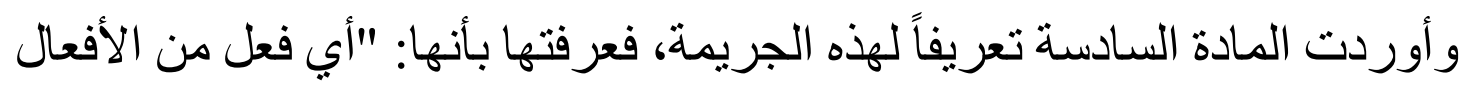

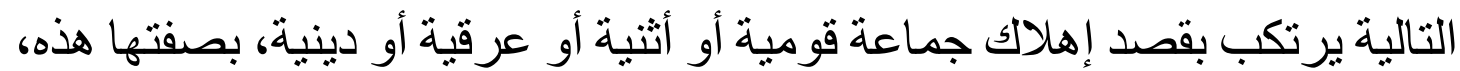

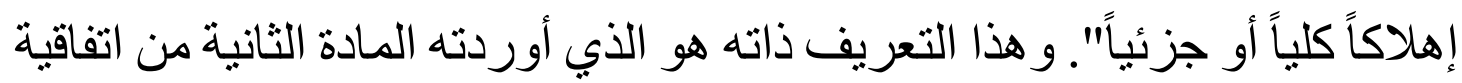

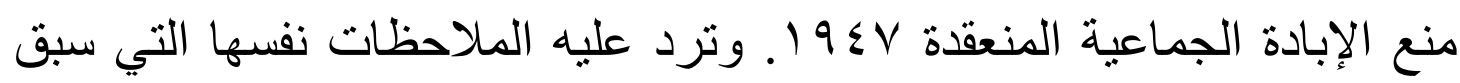

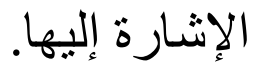

وقد أوردت المادة السادسة من النظام الأساسي أمثلة على الإبادة الجماعية 
r- إلحاق ضرر جسدي أو عقلي جسيم بأفر اد الجماعة. بـ إخضاع الجماعة عمداً لأحو ال معيشية يقصد بها إهلاكها الفعلي كلياً أو جزئياً. ع-فرض تدابير تستهدف منع الإنجاب داخل الجماعة. 0ـنقل أطفال الجماعة عنوة إلى جماعة أخرى. و هذه الحالات ذاتها التي أوردتها المادة الثانية من اتفاقية منع الإبادة الثادة

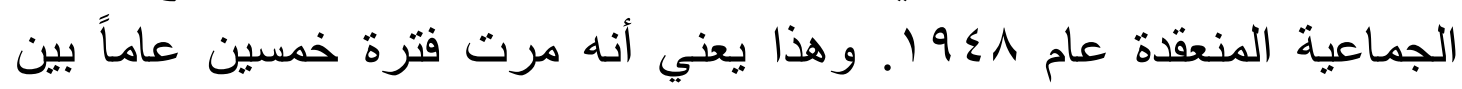

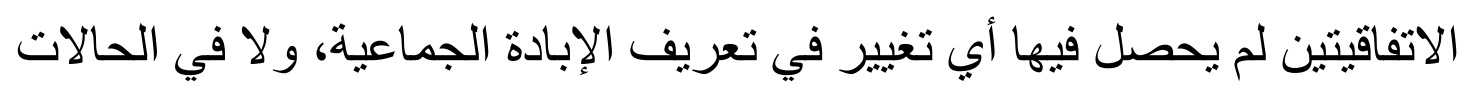

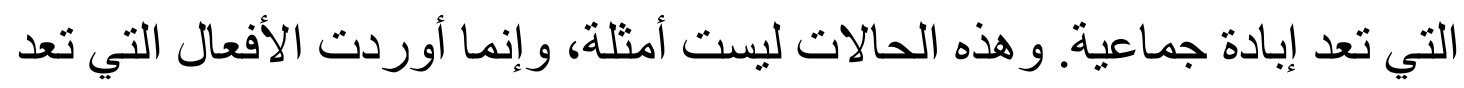

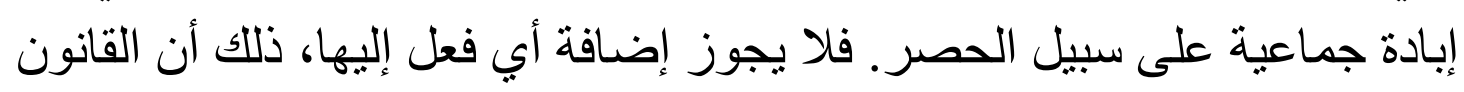

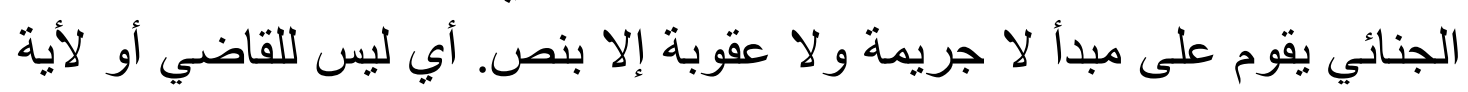

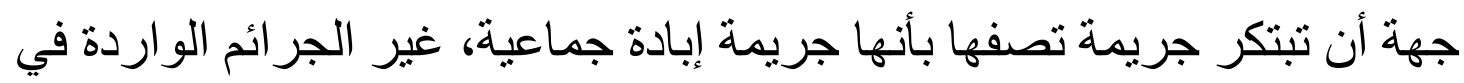

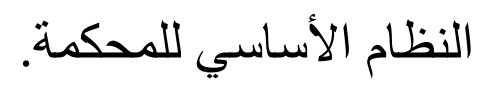

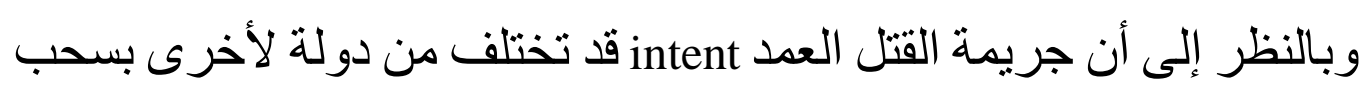

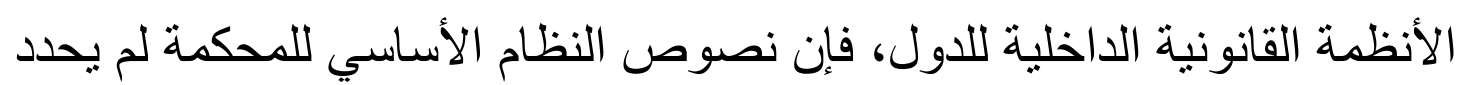

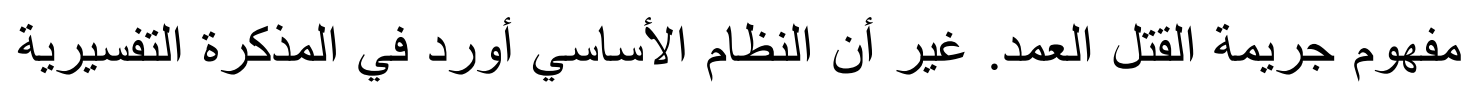

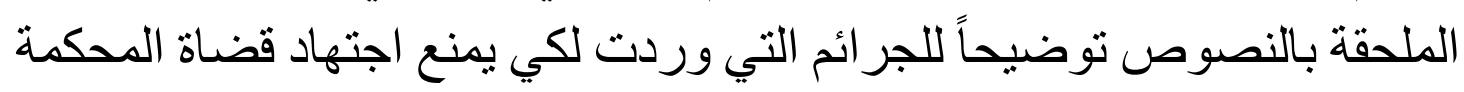

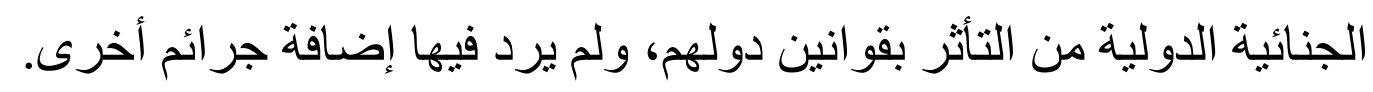

$$
\text { المطلب الثاني }
$$

\section{مفهوم جريمة القتل العدد فِي نَظَّام الََْحْكَمَة

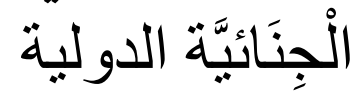

تعد جريمة القتل العمد Intent Killing Crime من أهم الجر ائم التي تتاولها

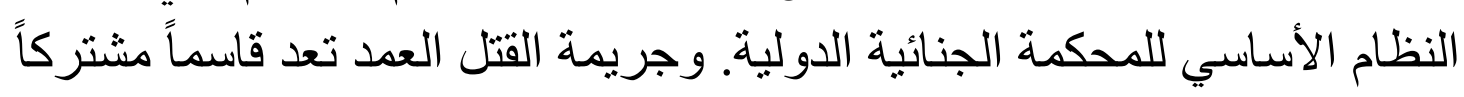

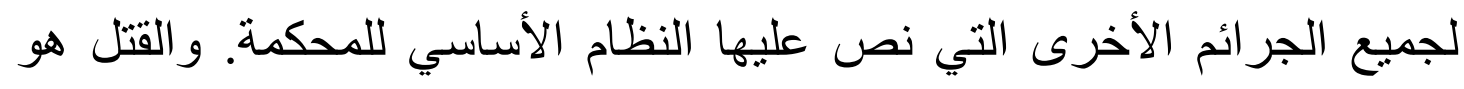

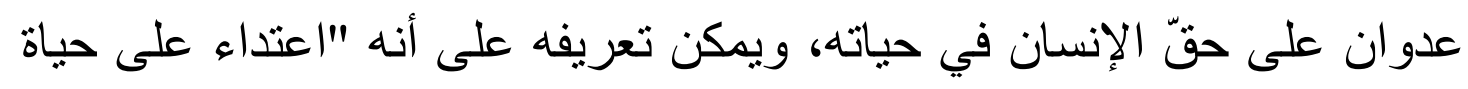

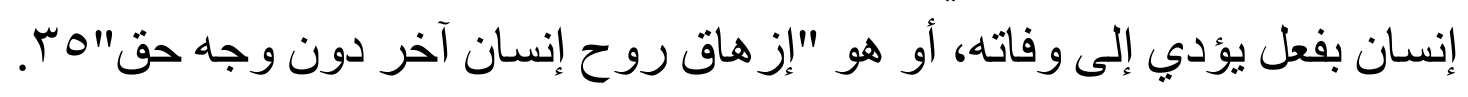

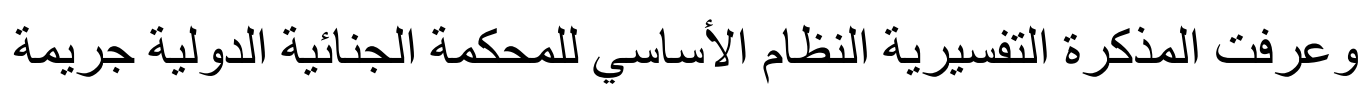

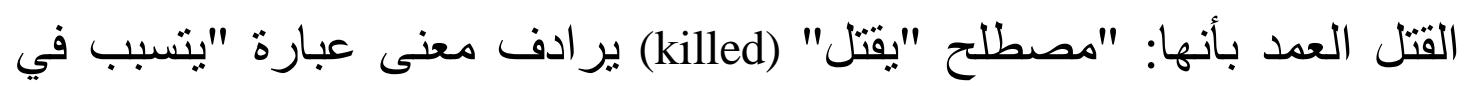


موت" (caused death) وتنسحب المذكرة التفسيرية على كل الأركان التي تستعمل

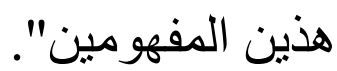
ويلحظ أن هذا التعريف ليس للقتل كاسم و إنما لفعل يقتل وعرفه النظام

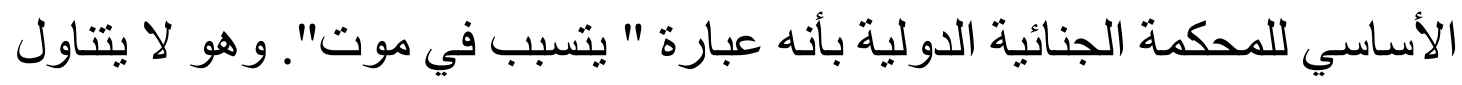
الفعل المجرد (يقتل) و لا يتناول الجانب القصدي الذي هو محل العقاب. واختلفت الآراء في تحديد جريمة القتل العمد في نطاق محكمة الجنايات الدولية وذهبت إلى مذاهب متعددة منها: الرأي الأول: يرى أن جريمة القتل العمد وفقاً لنظام الدحكمة الجنائية الدولية إلهاية

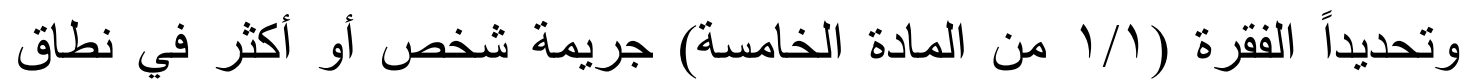

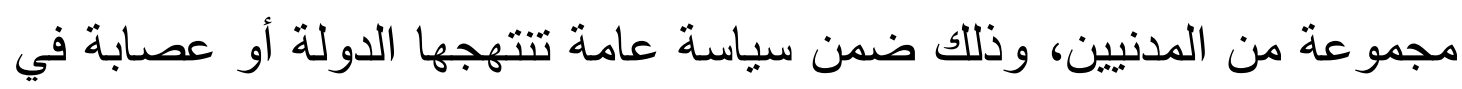

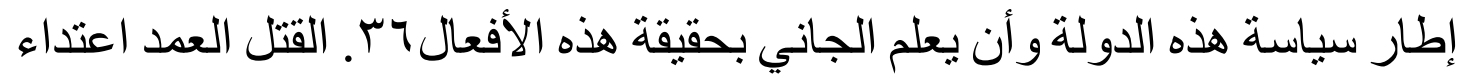

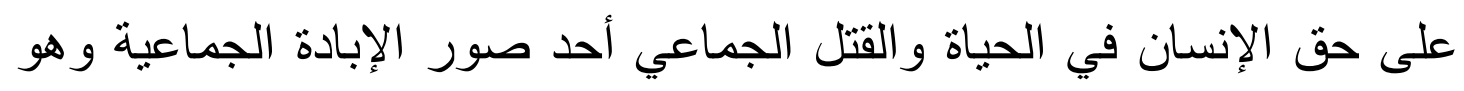

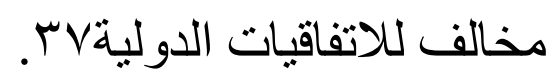
و الواقع أن هذه الحالة واحدة من الحالات التي أوردها النظام الأساسي لانسي

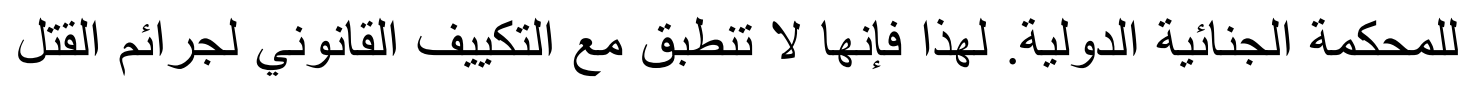

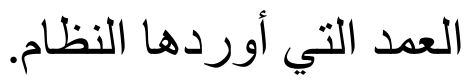

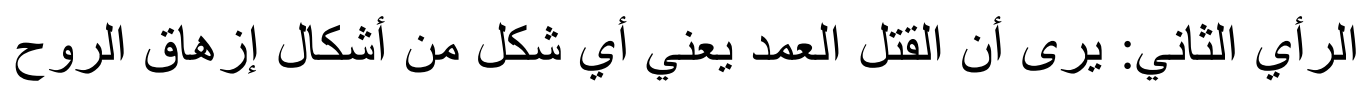

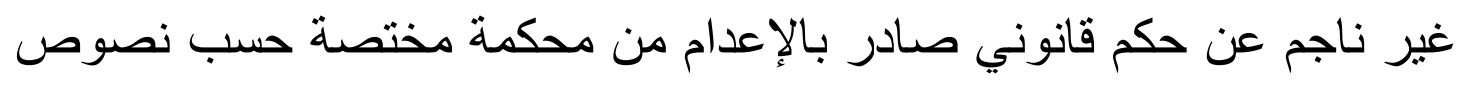

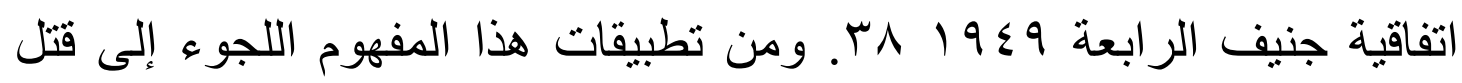

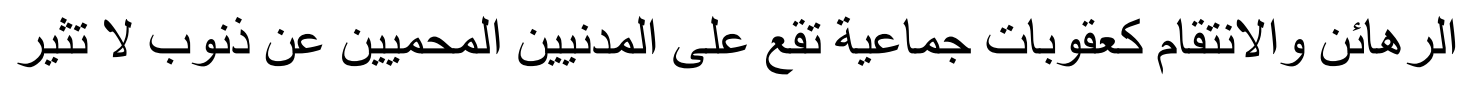

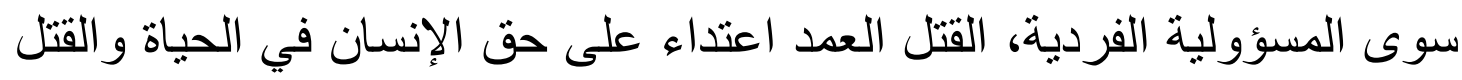
الجماعي أحد صور الإبادة الجماعية ويخالف الاتفاقيات الدوليةه بـ.

والو اقع أن هذا الر أي لا ينطبق مع نظام روما الأساسي للمحكمة الجنائية ولئية

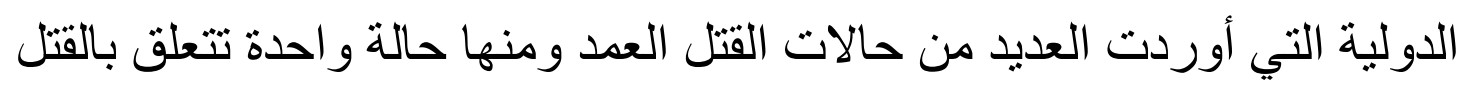

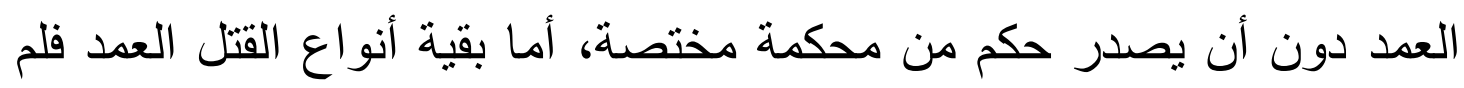

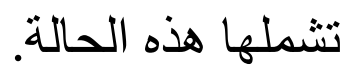


نرى أن جرائم القتل العدد في نطاق المحكمة الجنائية الدولية تشمل جوانب

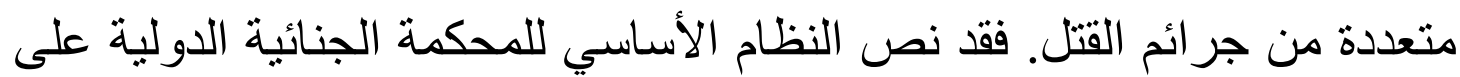
عدة جر ائم للقتل العمد وهي: اـالقتل العمد في إطار جرائم الإبادة الجماعية، والذي أطلق عليه قتل أفراد

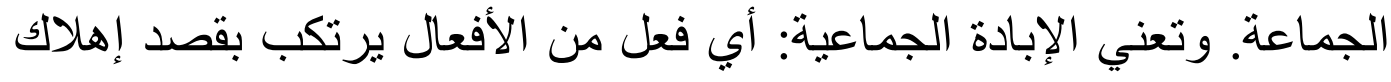

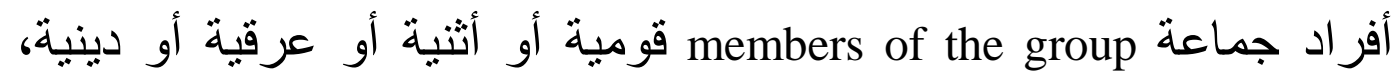

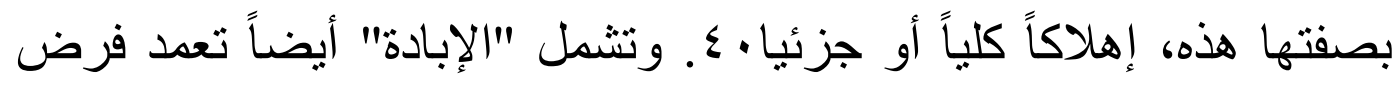

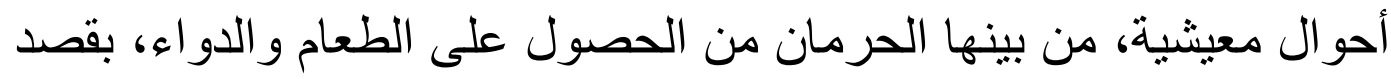
إهلاك جزء من السكان.

r-القتل العمد في إطار الجرائم المرتكبة ضد الإنسانية، متى ارتكبت في إطار هجوم واسع النطاق أو هجوم منهجي موجه ضد أية مجموعة من السكان، وعن علم بالهجوم.

r-القتل عن طريق الإبادة الجماعية في إطار الجرائم المرتكبة ضد الإنسانية،

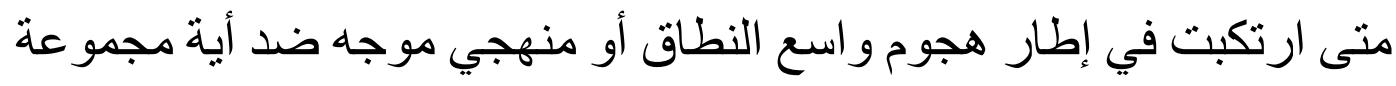

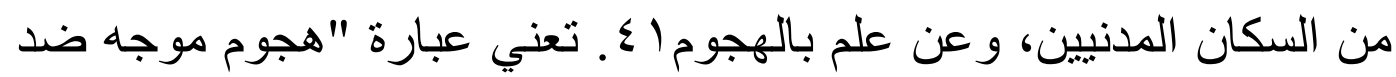

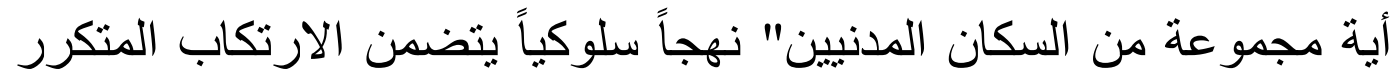

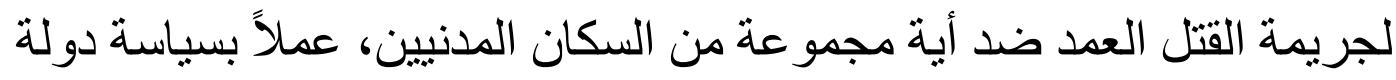

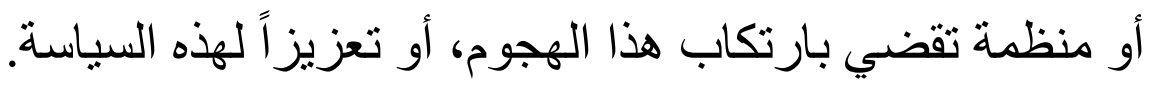
ع_القتل العمد في إطار جر ائم الحرب، عندما ترتكب في إطار خطة أو سياسية

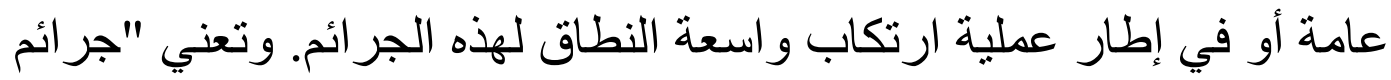

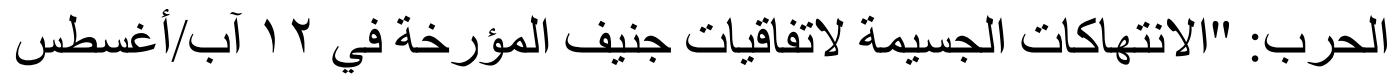

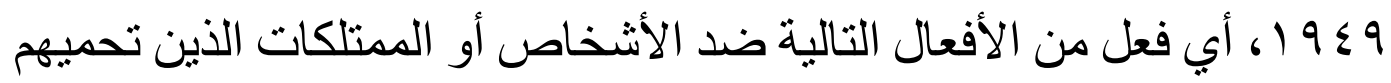
أحكام اتفاقية جنيف ذات الصلة فين الافعلة الصالة

○ـالقتل العمد عن طريق هجمات ضد السكان المدنيين بصفتهم هذه أو ضد أفر اد مدنيين لا يشاركون مباشرة في الأعمال الحربية.

7_القتل العمد عن طريق هجمات ضد مواقع مدنية، أي المواقع التي لا تشكل أهدافاً عسكرية.

V_القتل العمد في إطار شن هجمات ضد موظفين مستخدمين أو منشآت أو مو اد

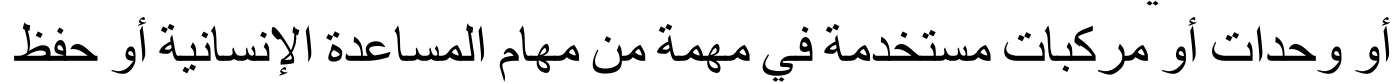


السلام عملاً بميثاق الأمم الدتحدة مادامو ا يستحقون الحماية التي توفر للمدنيين

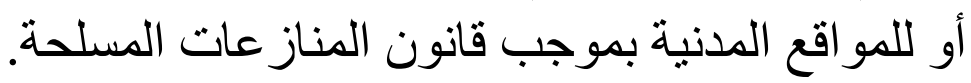

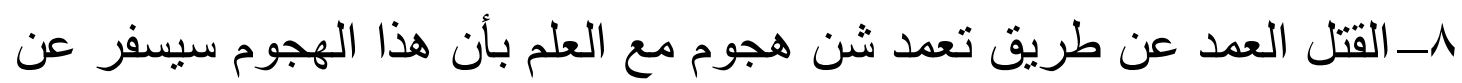

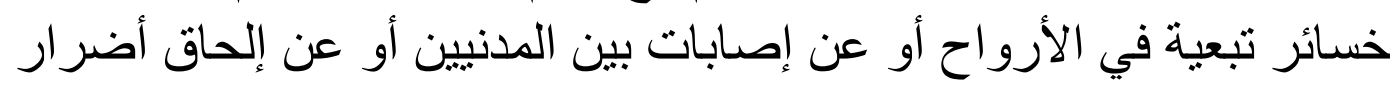

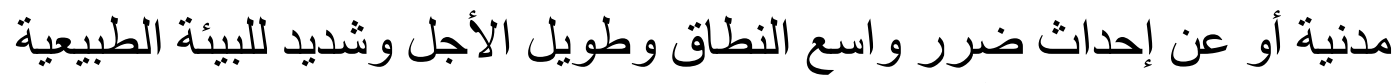

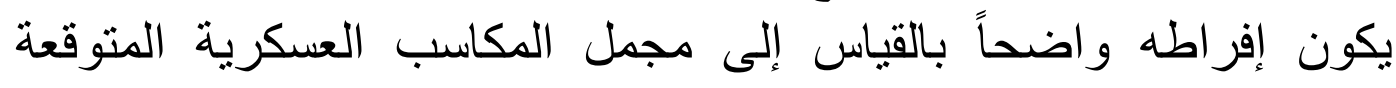

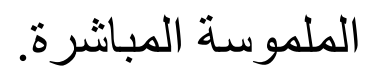

9-القتل العدد عن طريق مهاجمة أو قصف المدن أو القرى أو المساكن أو المباني العز لاء التي لا تكون أهدافاً عسكرية، بأية وسيلة كانت.

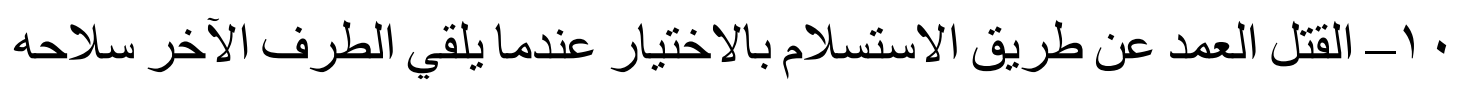

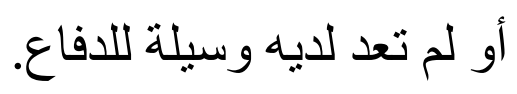

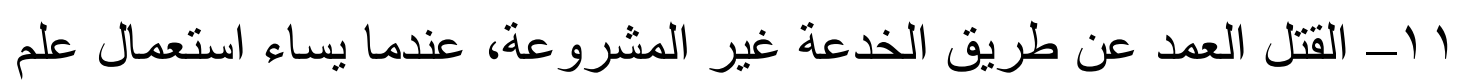

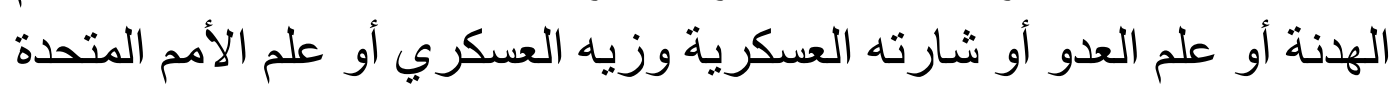

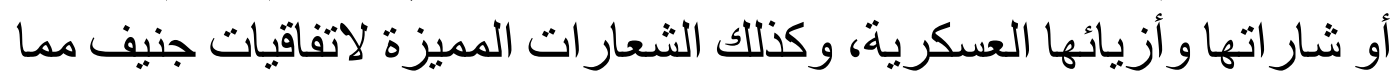
يسفر عن موت الأفر اد أو إلحاق إصابات بالغالغة بهر.

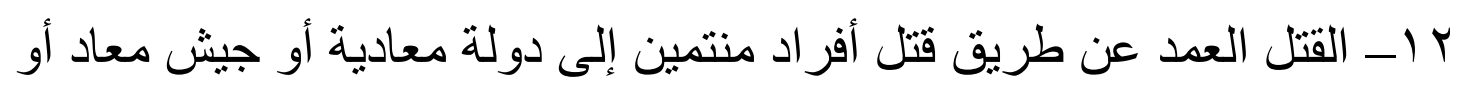

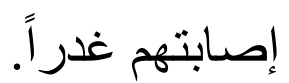

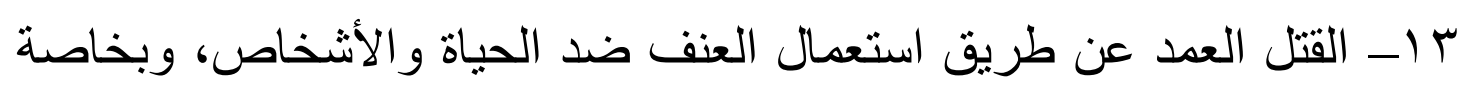
القتل بجميع أنو اعه، و التشويه.

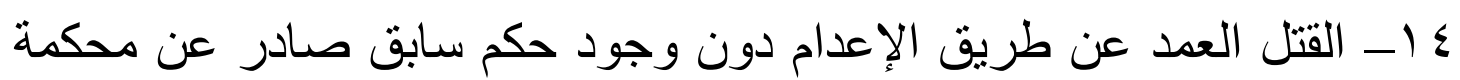

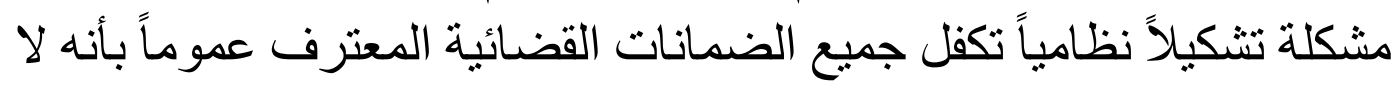
غنى عiها.

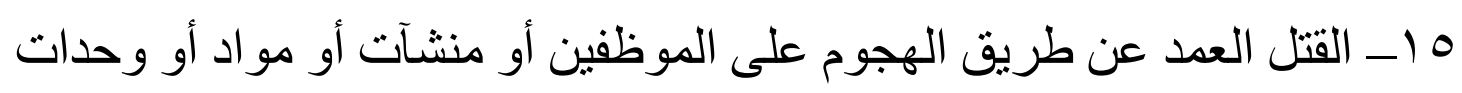

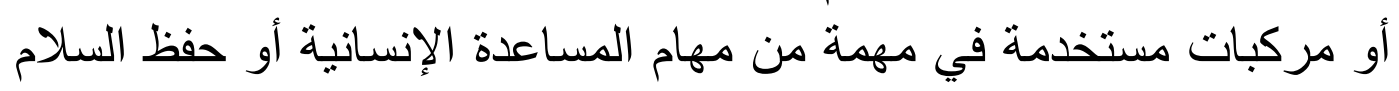

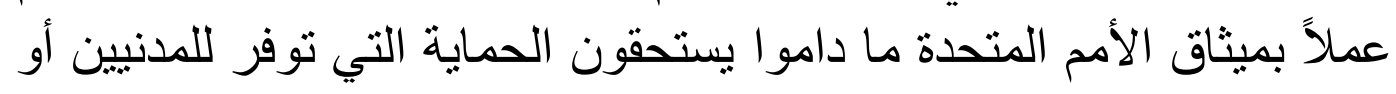

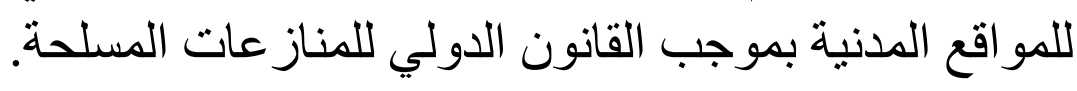

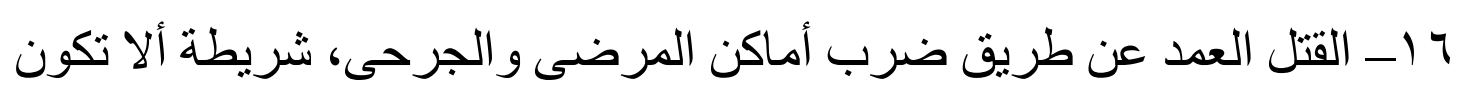

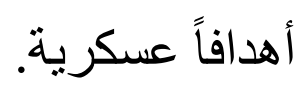


I ا ـ القتل العدد عن طريق الغدر، عندما يقتل أحد المقاتلين من العدو أو إصابته غدراً.

11 1ـ القتل العدد عن طريق الإعلان بأنه لن ييقى أحد على قيد الحياةץ ؟.

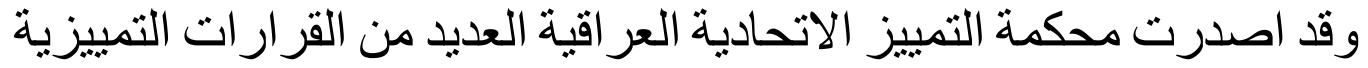

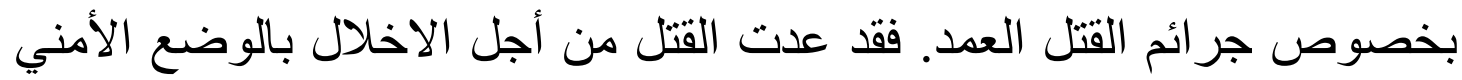

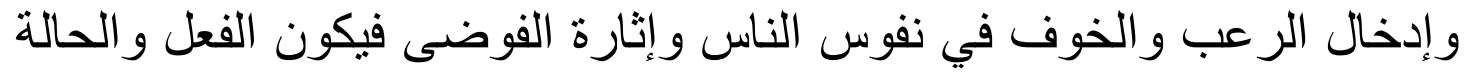

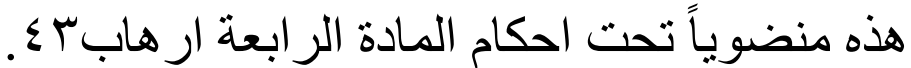

وعدت محكمة التمييز الاتحادية العر اقية القتل الجماعي لعدة أنثخاص من أنداص

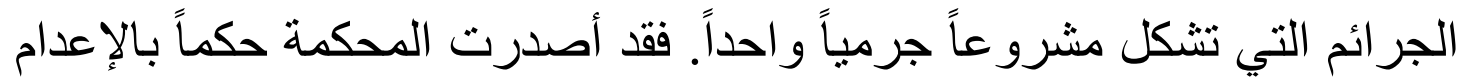

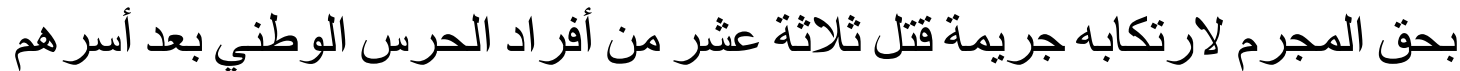

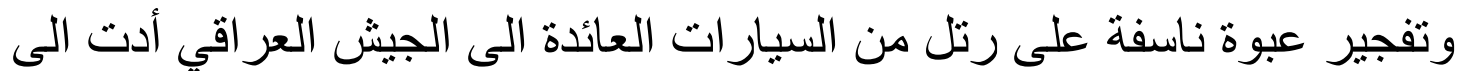

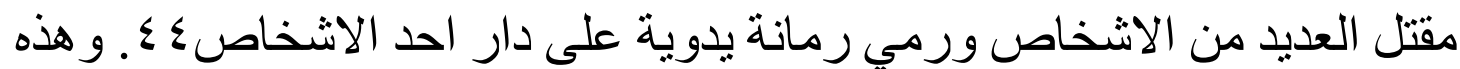
الجريمة من جرائم الإبادة الجماعية

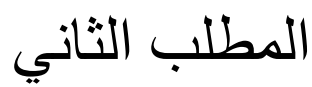

\section{أركان جريمة الابادة الجماعية}

\section{في ضوء النظام الأساسي للمحكمة الجنائية الدولية}

لا يمكن أن تقوم أية جريمة دون أن تتحقق أركانها. و اختلف الفقه في أركان

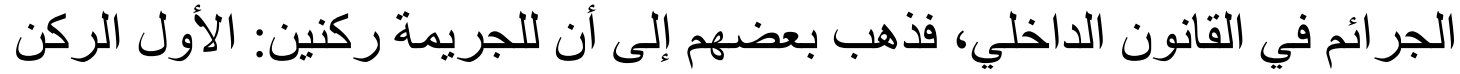

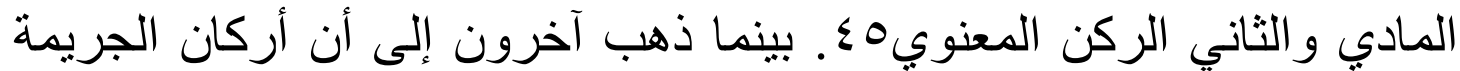
ثلاثة: وهي الركن الثرعي و الركن المادي و الركن المعنوي 4 ــ.

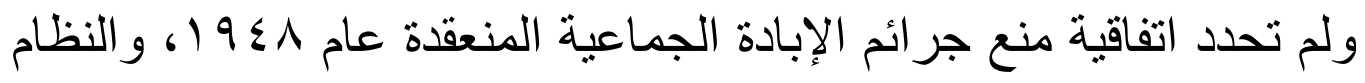

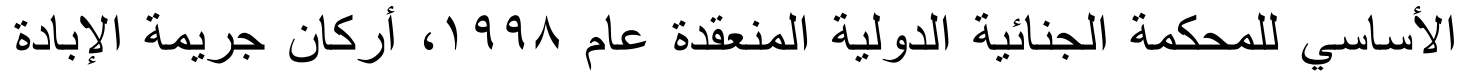

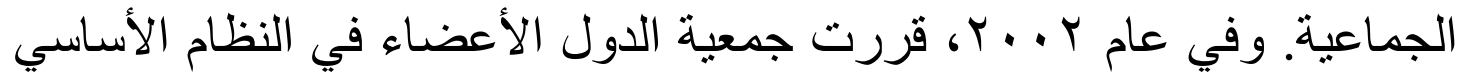
للمحكمة الجنائية الدولية اعتماد أركان الجر ائم ومنها جريمة الإبادة الجماعيةلاعــ. وحددت ديباجة قرار الدول الأعضاء في النظام الأساسي بأن محكمة

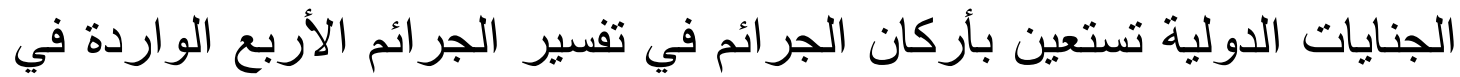

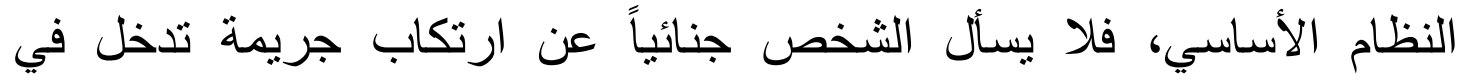


اختصاص المحكمة ولا يكون عرضة للعقاب على هذه الجريمة، إلا إذا تحققت الأركان المادية للجريمة مع تو افر القصد و العلم. وإذا لم ترد إثشارة في الأركان

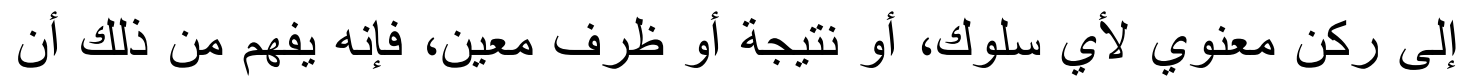

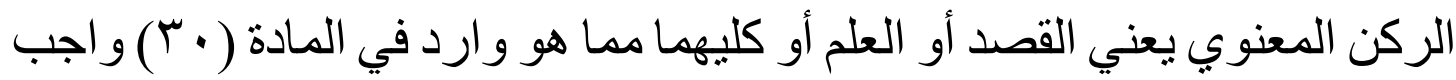
التطبيق.

وترد الحالات المستثناة من معيار المادة • ب وفقاً للنظام الأساسي بما في

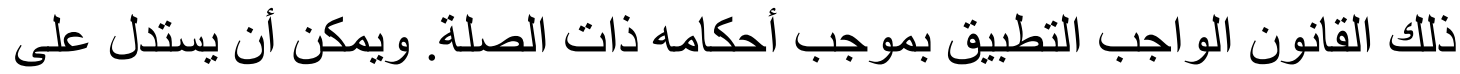
وجود القصد و العلم من الوقائع والظروف ذات البون الصلة. وفيما بتعلق بالأركان المعنوية المتصلة بالأركان التي تنطوي على حكم للقيمة مثل تلك التي ولتي تستخدم فيها مصطلحات "اللاإنسانية" أو "الثديدة"، فليس من الضري علئ هروري أن يكون

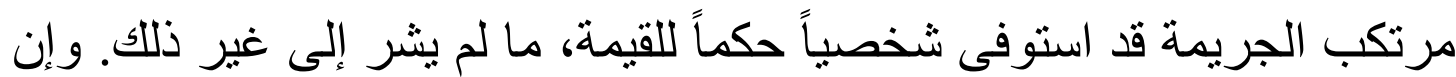

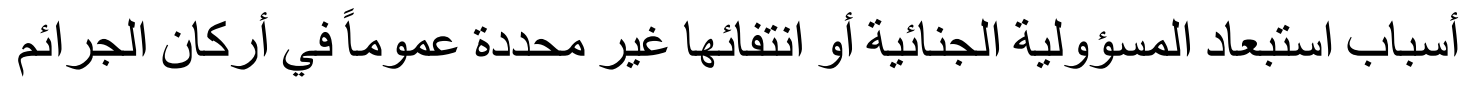
المبينة تحت كل جريمة. ويعد شرط "عدم المشروعية" الموجود في النظام

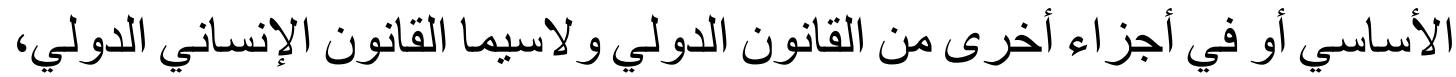
غير محدد عامة في أركان الجر ائم. وتتظم أركان الجر ائم عامة وفقاً للمبادئ التالية:

1 ـ عندما تتصب أركان الجرائم على السلوك و النتائج و الظروف المرتبطة بكل جريمة فإنها ترد كقاعدة عامة بذلك الترنيب. r- عند الاقتضاء سيورد ركن معنوي معين بعد ما يتصل به من سلوك أو نتيجة أو ظرف. ب-تورد الظروف السياقية في النهاية. ع_كما هو مستخدم في أركان الجريمة، فإن مصطلح "مرتكب الجريمة" مصطلح محايد فيما يتعلق بثثوت الإدانة أو البراءة أنئ.

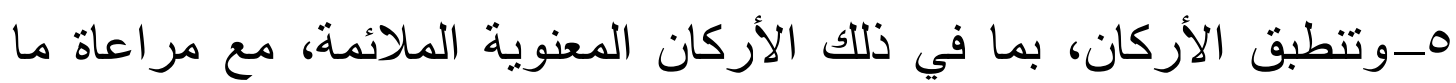

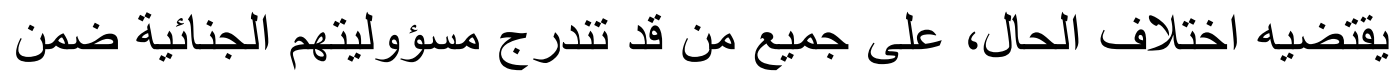

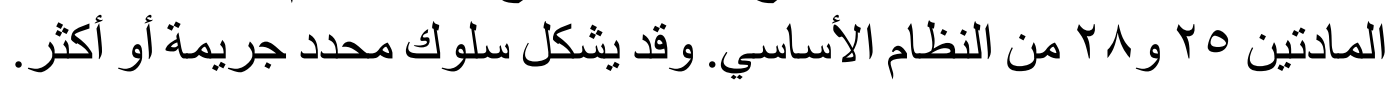
7-ليس لاستخدام العناوين القصيرة للجر ائم أي تأثير قانوني. 


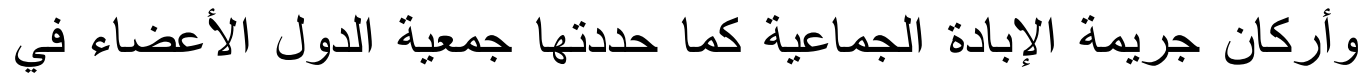

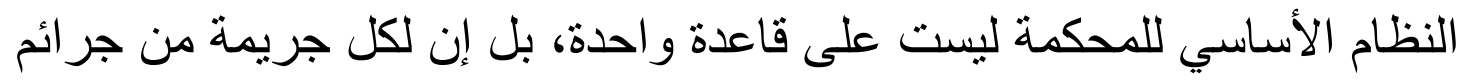

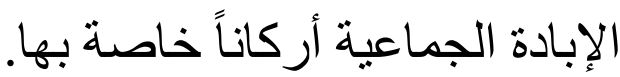

وحددت المادة السادسة من أركان الجرائم جريمة الإبادة الجماعية الخاصة

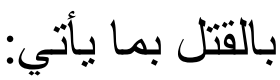

1 - أن يقتل مرتكب الجريمة شخصاً أو أكثر. ومعنى مصطلح "يقتل" (killed)

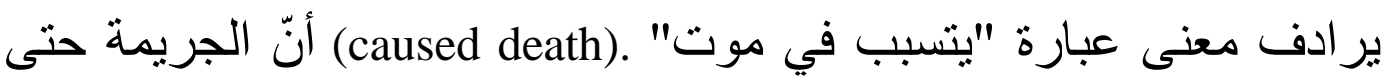

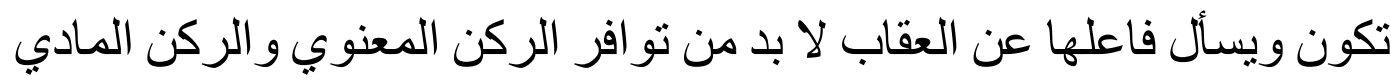

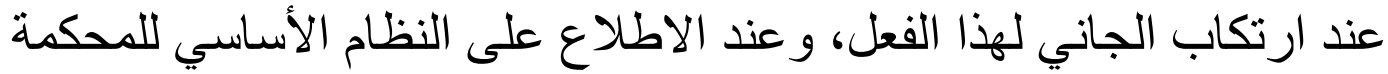

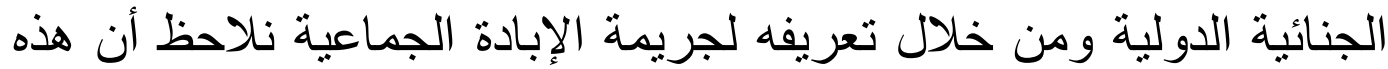

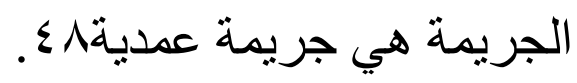

r- أن يكون الثخص أو الأشخاص منتمين إلى جماعة قومية national أو إثنية racial أو دينية rethnical

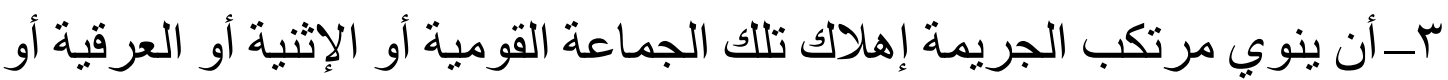

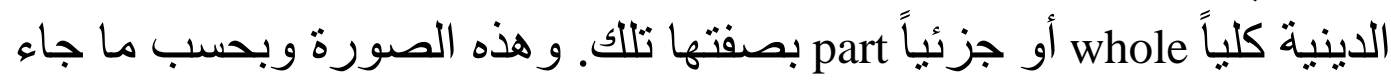
في النظام الأساسي للمحكمة الجنائية الدولية تتصرف إلى إلى كافّة الأفعال المادية

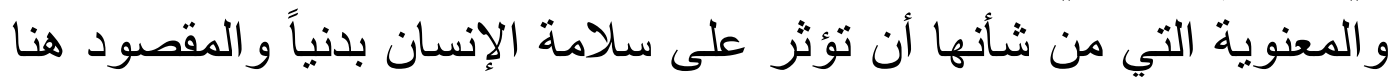

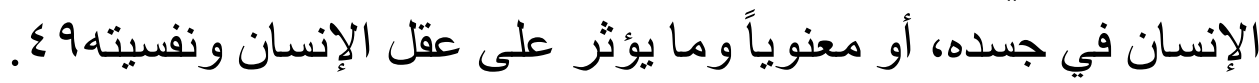

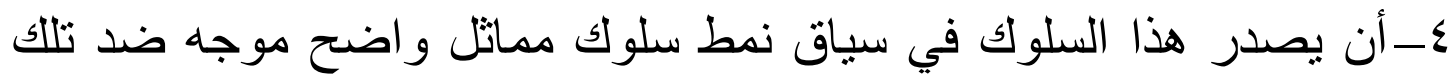
الجماعة أو يكون من شأن السلوك أن يحدث بحد ذاته ذلك الك الإهلاك .0.

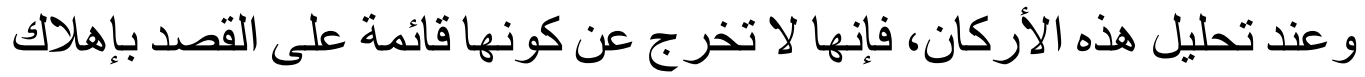

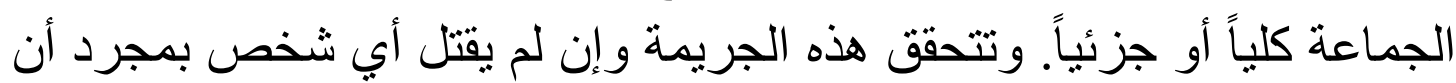

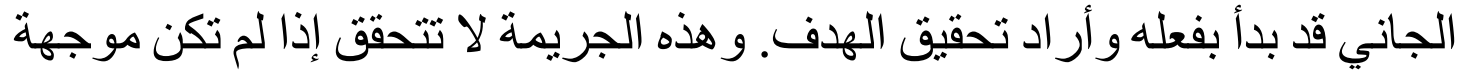

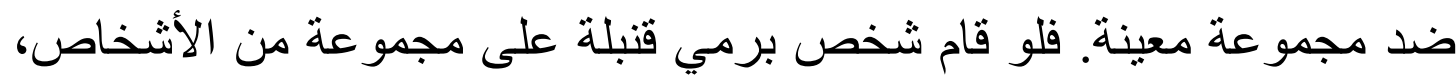

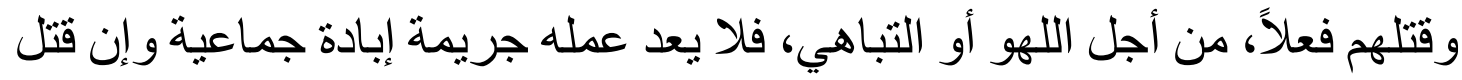
مجمو عة كبيرة، ويكون وصف الجل جريمة أخرى.

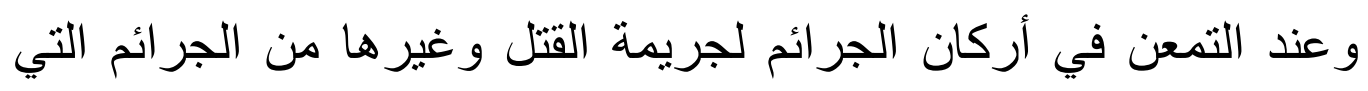

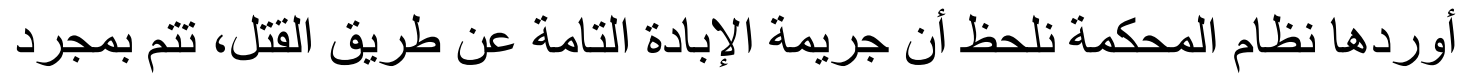

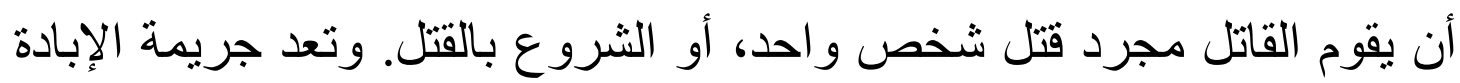




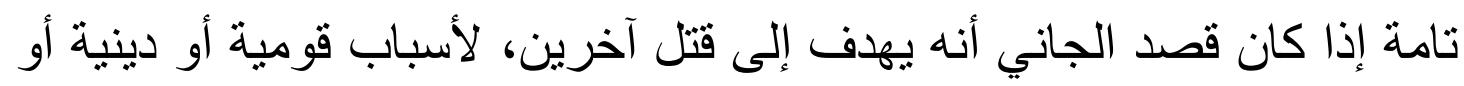

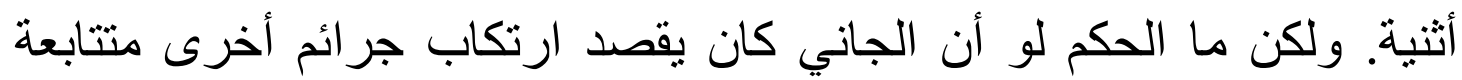

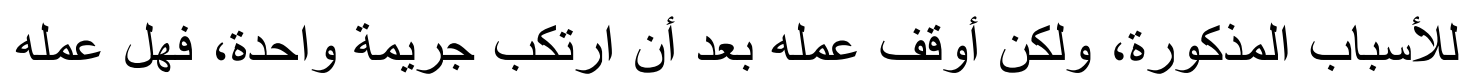

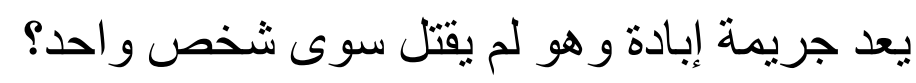

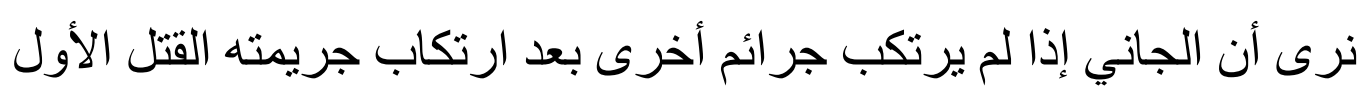

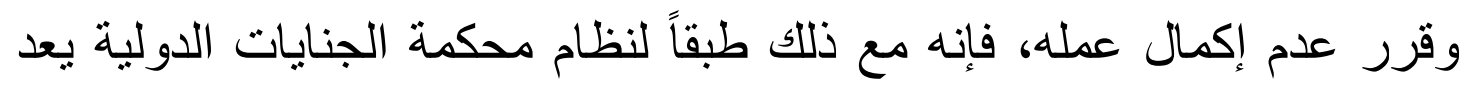

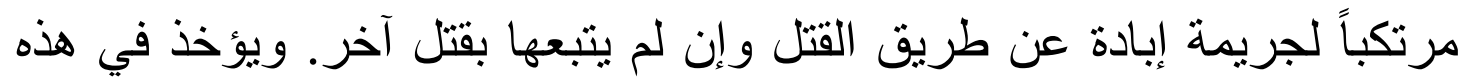

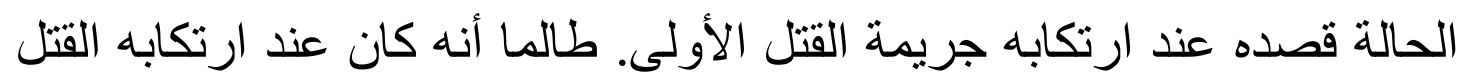

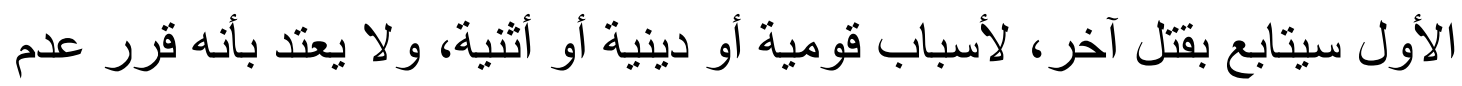

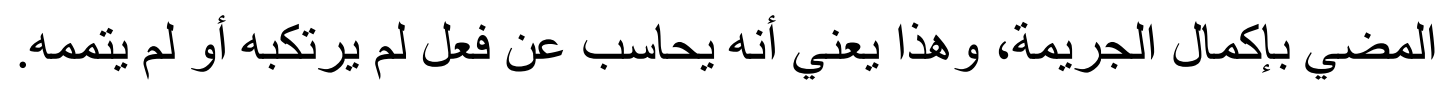

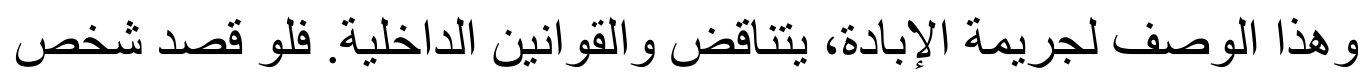

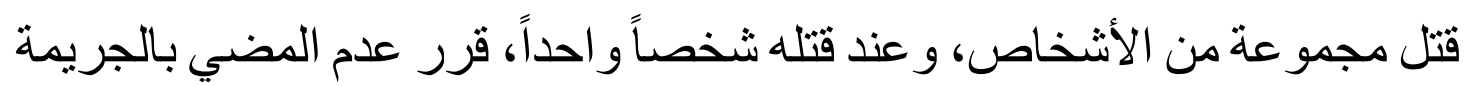

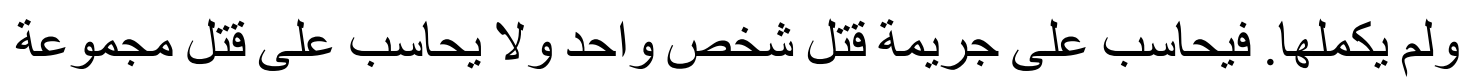

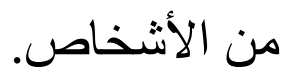

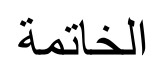

خلصت در اسة جريمة الإبادة الجماعية كجريمة دولية وما لها من دور كبير

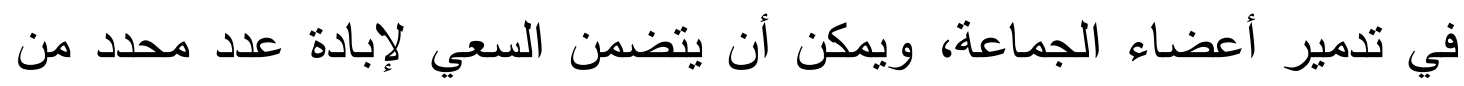

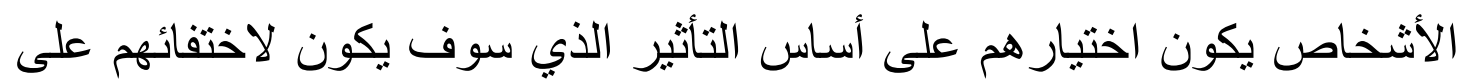
باقي الجماعة، و عليه فإننا نكون أمام إرادة الإبادة الجماعية.

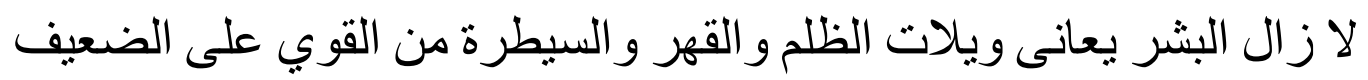

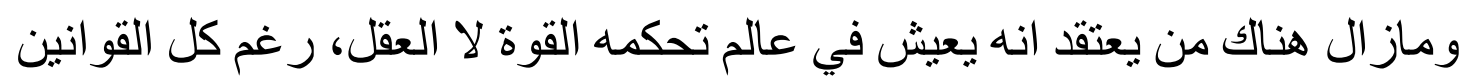

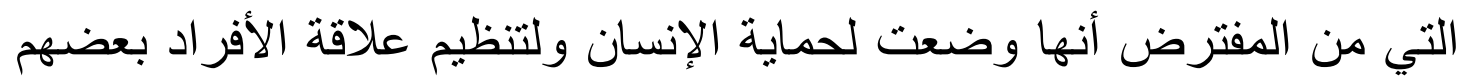

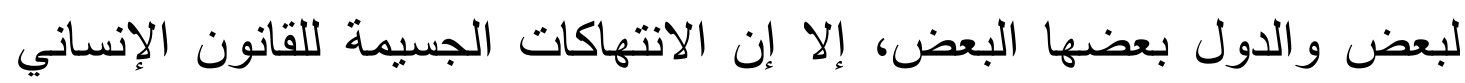

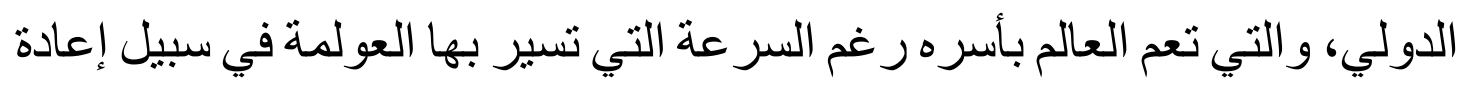

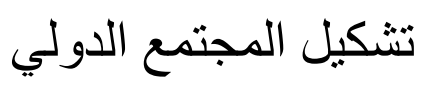

إن الأفعال الخمسة المكونة لجريمة الإبادة الجماعية لا تثكل في حد ذاتها

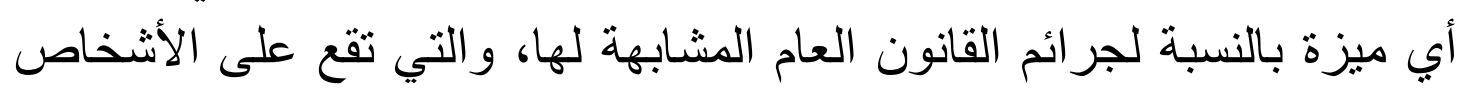

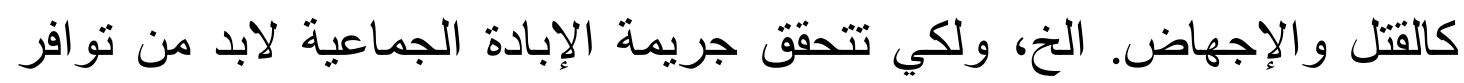


ركنين أساسيين وهما الفعل أو امتناع المجرمين. و النية تعتبر معيار اً محدداً يميز

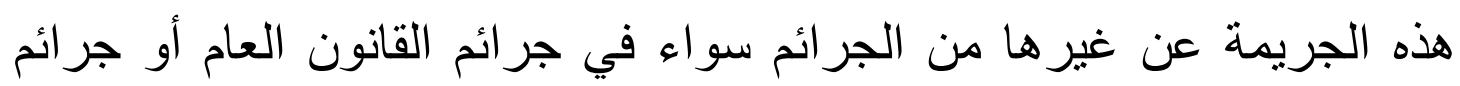

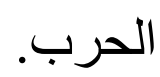

هذه الجريمة ليس بالضرورة أن يرتكبها مو اطن دولة ضد دولة أخرى،

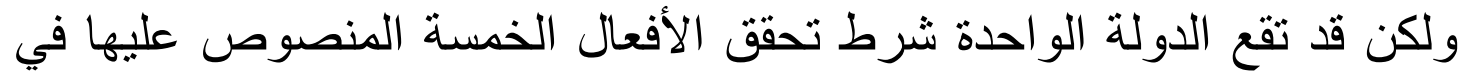
المادة السادة من النظام الأساسي (روما) لهحكمة الجنائية الدولية.

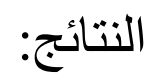

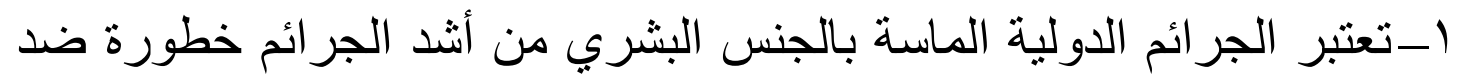

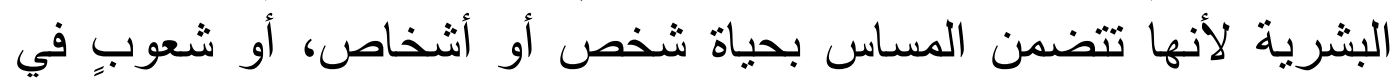
حريتهم وحقوقهم و أدمينهم، وتثنكل في مجمو عها جر ائم إنسانية.

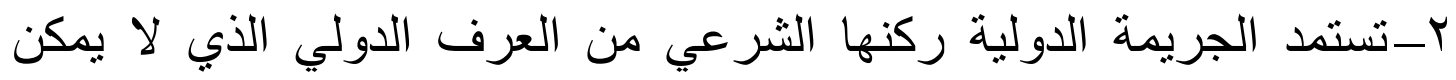

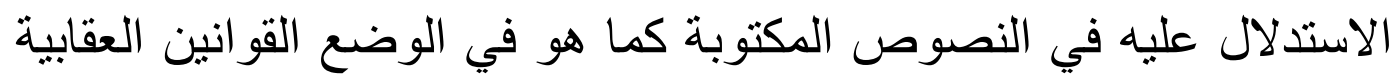
الداخلية. لذلك توجد صعوبة كبيرة في التعرف على الجريمة الدولية.

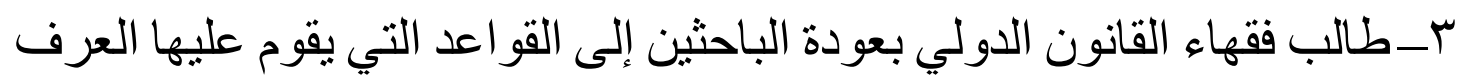
الدولي مثل قو اعد العدالة والأخلاق.

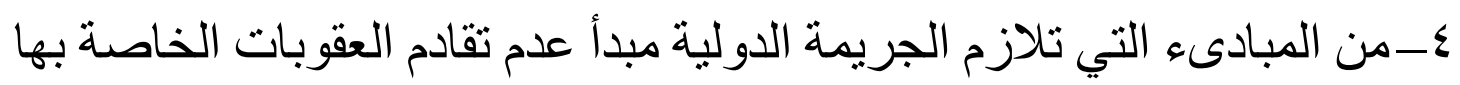
مهما كان تاريخ ارتكابها.

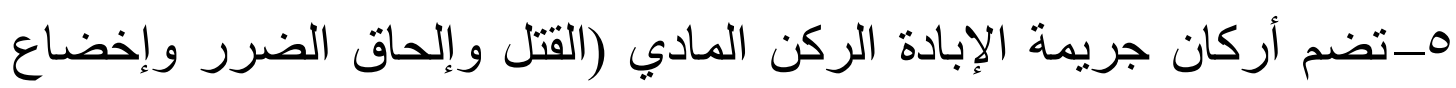

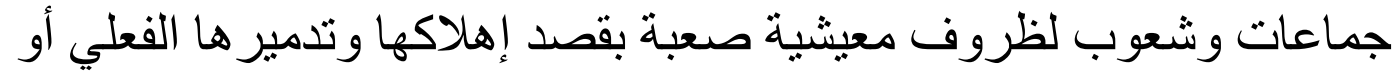

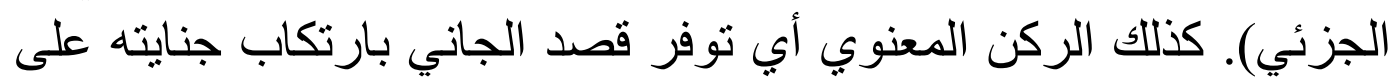

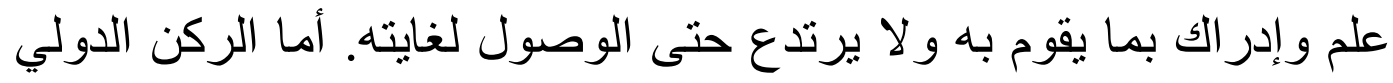

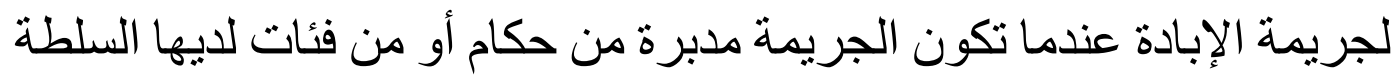

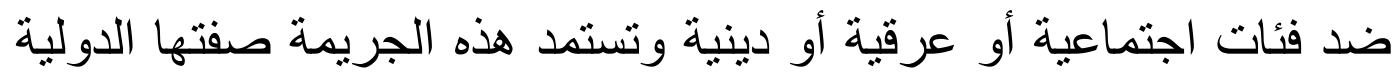
بسبب مصلحة دولية. 


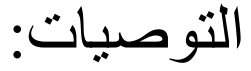

$$
\text { توصي الدر اسة بما يلي }
$$

1-وضرورة تفعيل الدور للمحاكم الدولية في التصدي لجريمة الإبادة الجماعية

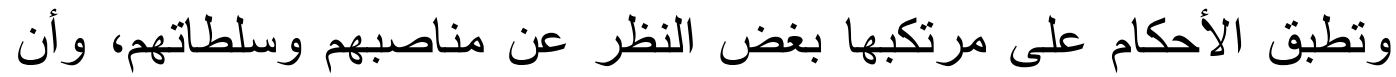

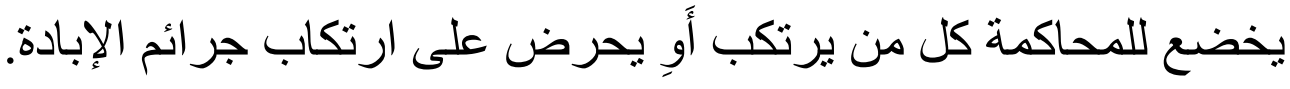

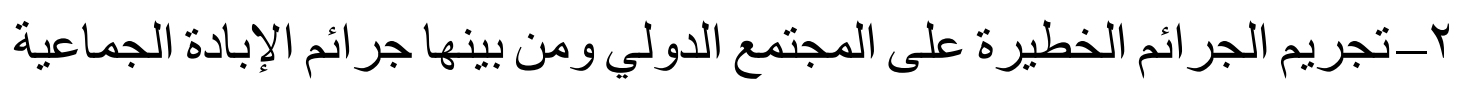

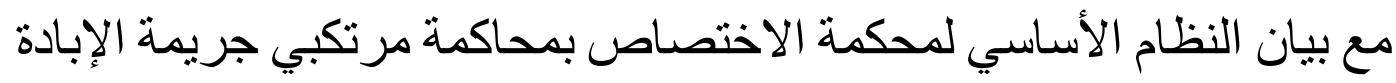

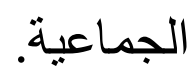

r-على كافة الدول أن تتبنى إقرار مبادىء متفق عليها لمواجهة جريمة الإبادة الجماعية بكافة صور ها المادية و المعنوية و الثقافية.

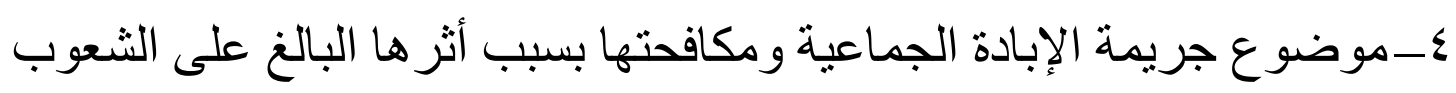

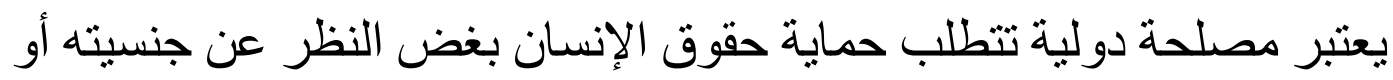

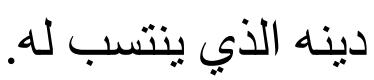

0_منع الدول الغنية من دعم المنظمات الارهابية مادياً و عسكرياً.

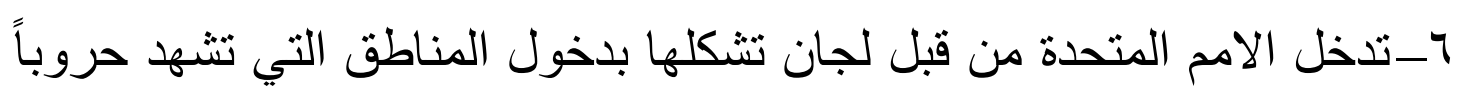
دولية او اهلية للتأكد من عدم ارتكاب جرائم الابادة الجماعية.

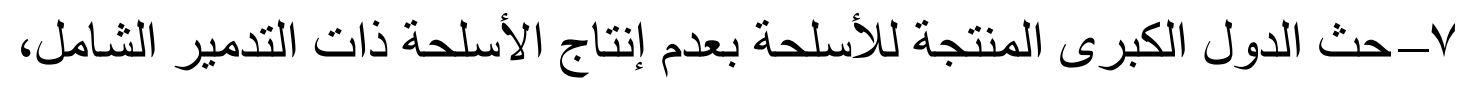

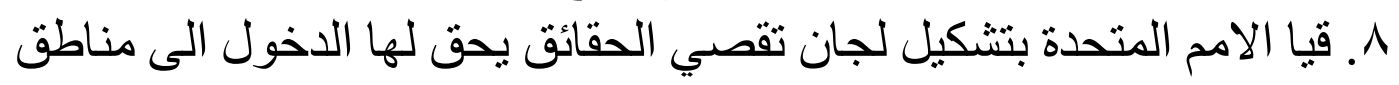
الصر اع للتاكيد من عدم ارتكاب جرائم ابادة جماعية. 


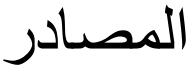

1 - أبو الخير أحمد عطية: المحكمة الجنائية الدولية الدائمة، دار النهضة العربية،

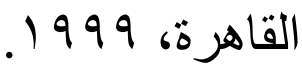

r-أنثرف توفيق شمس الدين، مبادئ القانون الجنائي الدولي، دار النهضة

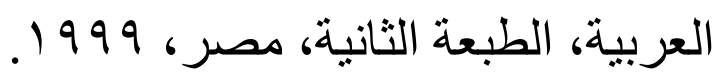

ץـاشرف فايز اللمساوى، المحكمة الجنائية الدولية، الطبعة الأولى، السنة

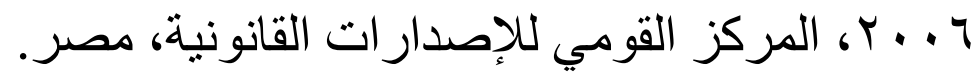

ع-حسام علي الثيخة: جر ائم الحرب في البوسنة والهرسك، دار الجامعة الجديدة،

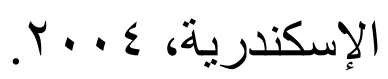

0-ضاري خليل محمود، باسل يوسف، المحكمة الجنائية الدولية، هيمنة القانون

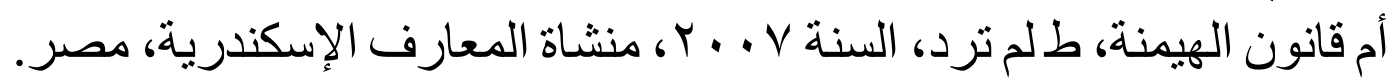
T-عباس هانشم السعدي، مسؤولية الفرد الجنائية عن الجريمة الدولية، دار

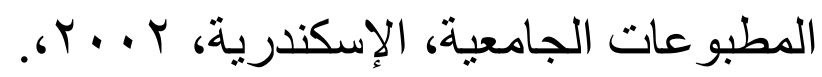

Y_ عبد الرحمن توفيق، محاضرات في الأحكام العامة لقانون العقوبات، دار

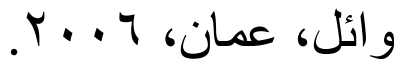

1_ـعبد الرحيم صدقي، القانون الجنائي و القسم العام، ج)، ، دار شعس المعرفة،

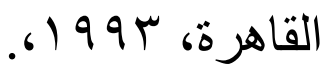

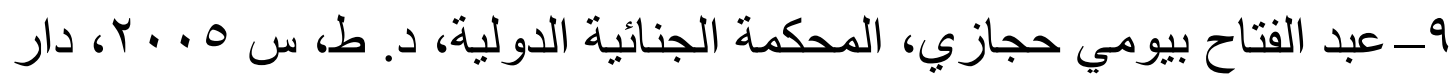
الفكر الجامعي، الإسكندرية، مصر. • 1 ـ عبد القادر البقير ات، العدالة الجنائية الدولية، ديوان المطبوعات الجامعية،

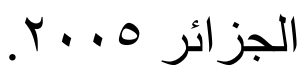

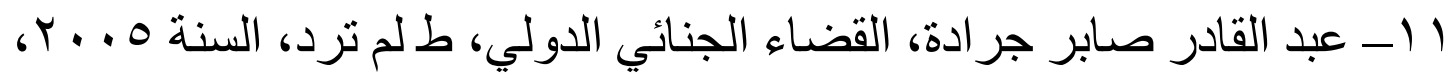
دار النهضة العربية، مصر.

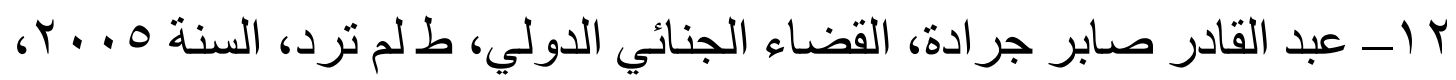

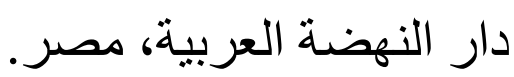


rا ا- عبد الله سليمان سليمان، المقدمات الأساسية في القانون الدولي الجنائي،

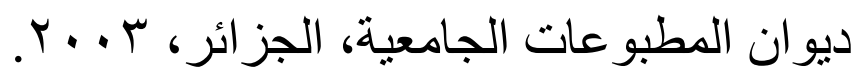

؛ (- علا عزت عبد المحسن، اختصاص المحكمة الجنائية الدولية، القاهرة، r...

10- علي صـادق أبوهيف: القانون الدولي العام، منشأة دار المعارف، الإسكندرية، بدون سنة نشر.

الـ علي يوسف الثكري، القانون الجنائي الدولي في عالم متغير، إيتر الك للطباعة و النشر مصر الجديدة.

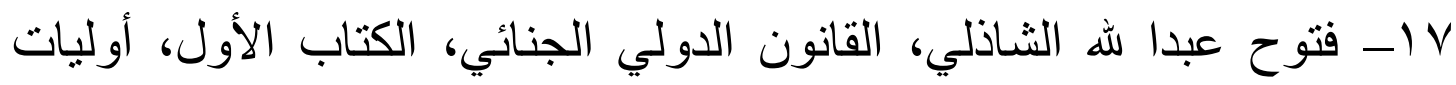

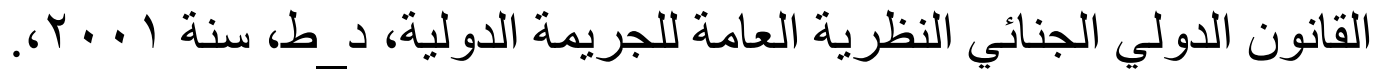

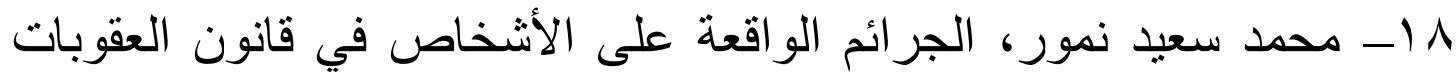

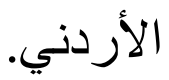

9 1ا- محمد عبد المنعم عبد الغني، الجرائم الدولية، رسالة دكتور اه، جامعة الإدية

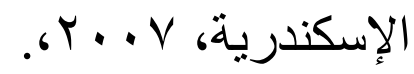

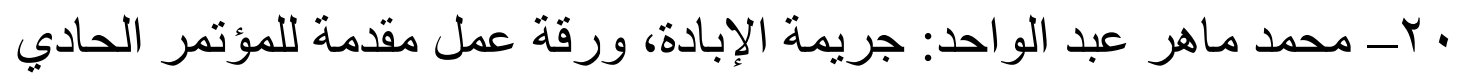

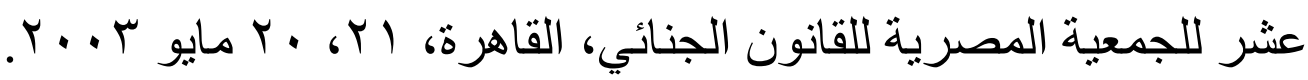

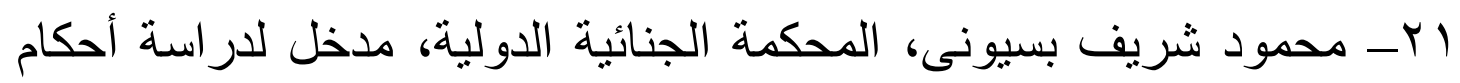

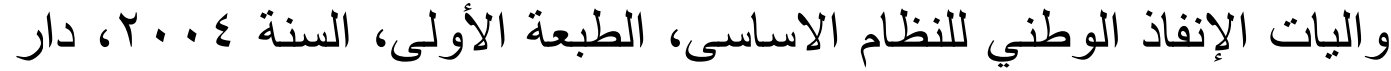

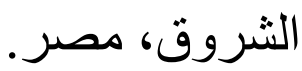

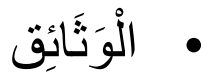

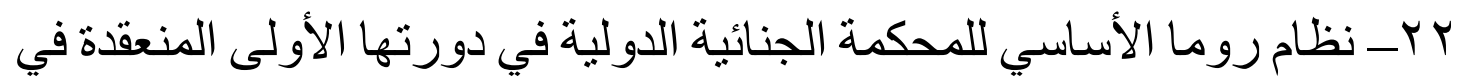

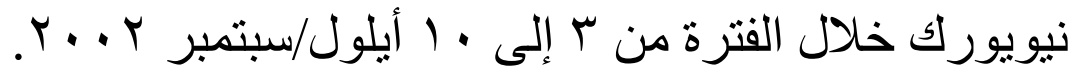

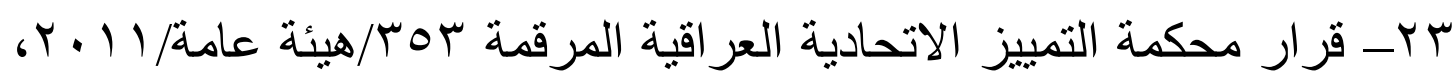

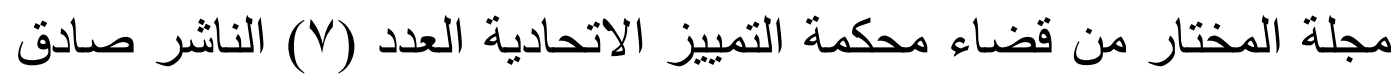

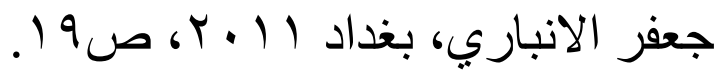
צ r- وثيقة الأمم المتحدة: وثيقة الأمم المتحدة. (ICC - ASP/1/3 SUPP) • الََْصَادِر الْأَجْنَبِيَّة 
Lawrence J. Leblanc: The United States and the Genocide-Yo Convention, Duke University Press, London, 1991.

26- Leo Kuper: International Action against Genocide, Minority Rights Group, 1984.

27- Roy Gutman: A Witness to Genocide: The 1993 Pulitzer Prize Winning Dispatches on the ethnic cleansing of Bosnia, Macmillan Publishing Company, New York, 1993. 


\section{الهو امش}

-2 - 1 عبد الفتاح بيومي حجازي، المحكمة الجنائية الدولية، دار الفكر الجمعي، الإسكندرية irrut. . . بـــانظرُ: أبو الخير أحمد عطية: المحكمة الجنائية الدولية الدائمة، دار النهضة العربية، القاهرة،

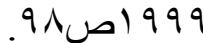
ع- حسام علي الثيخة: جرائم الحرب في البوسنة والهرسك، دار الجامعة الجديدة، الإسكندرية،

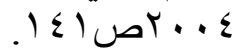
0ـ دخلت هذه الاتفاقية حيز النفاذ في ب / / / / 1901، انظر أنشرف توفيق شمس الدين، مبادئ القانون

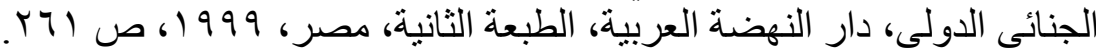

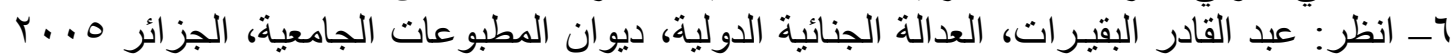

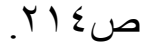
V-_ عبد الله سليمان سليمان، المقدمات الأساسية في القانون الدولي الجنائي، ديوان المطبو عات الجامعية،

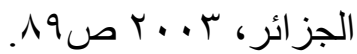
^- علي يوسف الثكري، القانون الجنـائي الدولي في عالم متغير، إيتر الك للطباعة والنشر مصر الجديدة صنr.

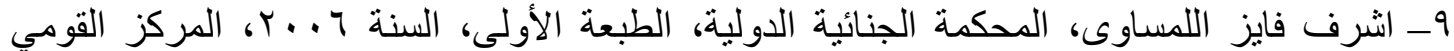

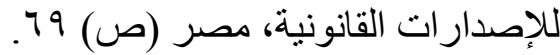

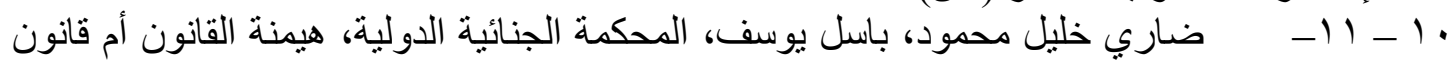

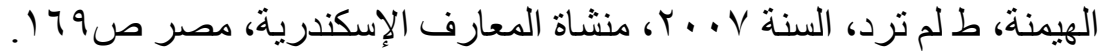

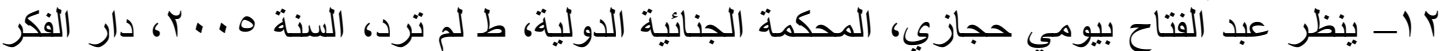

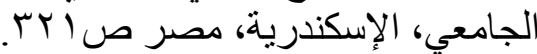

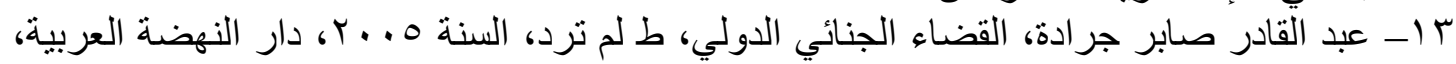

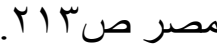
ـ اــ اثرف فايز اللمساوى، المحكمة الجنائية الدولية، الطبعة الأولى، السنة ج ـ. ــ، المركز القومي

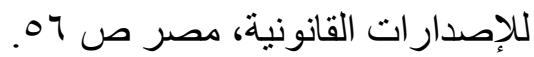

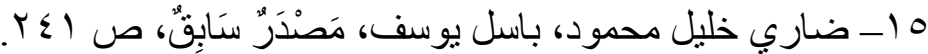

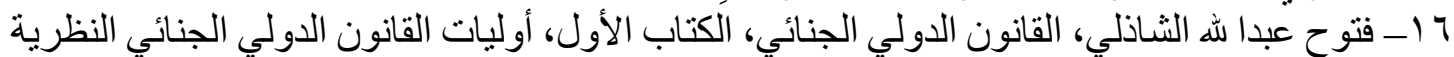

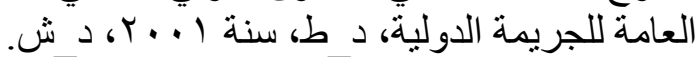

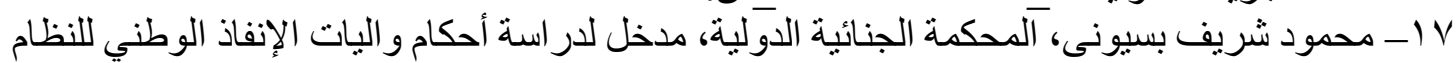

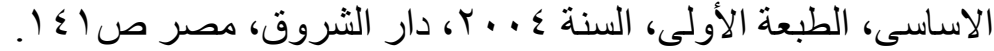

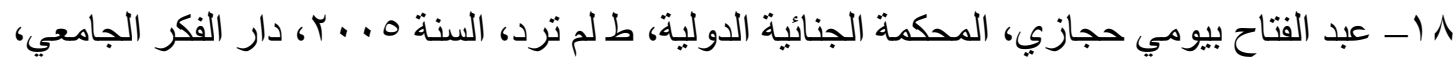

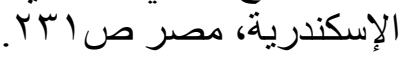

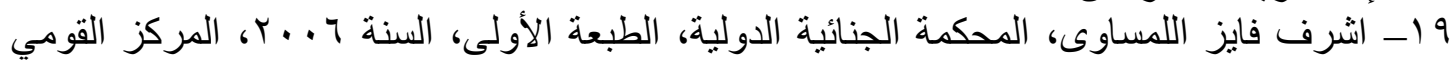

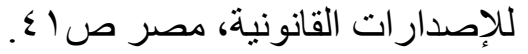

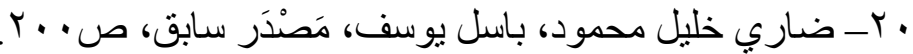

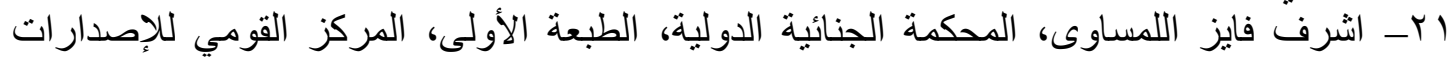

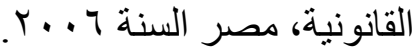

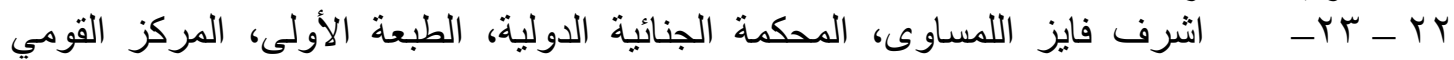

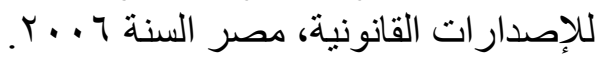

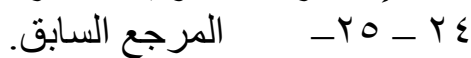

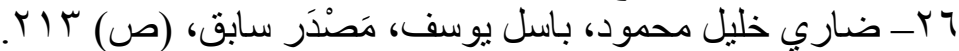




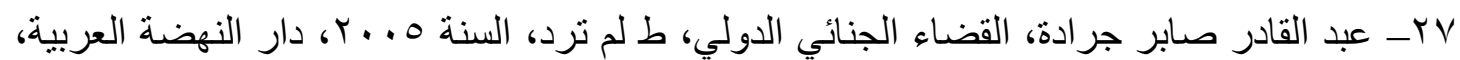

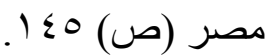

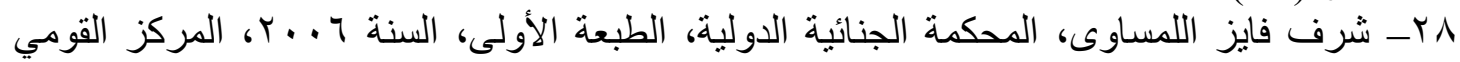

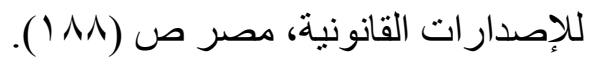

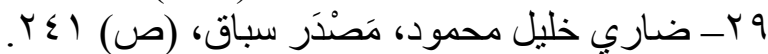

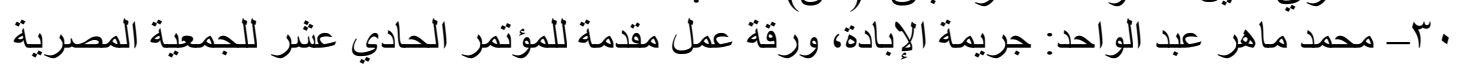

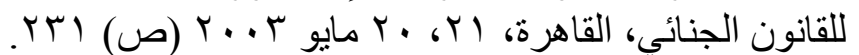

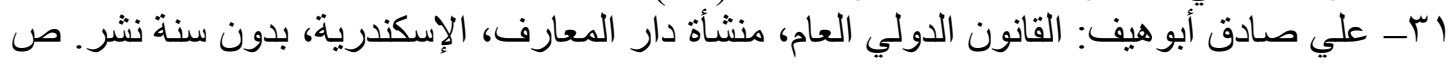

Lawrence J. Leblanc: The United States and the Genocide Convention, $-{ }^{r}$ r

Duke University Press, London, 1991. p. 20

33- Leo Kuper: International Action against Genocide, Minority Rights

$<$ Group, 1984. p. 12

Roy Gutman: A Witness to Genocide: The 1993 Pulitzer Prize - - r Winning Dispatches on the ethnic cleansing of Bosnia, Macmillan

Publishing Company, New York, 1993. p. 23.

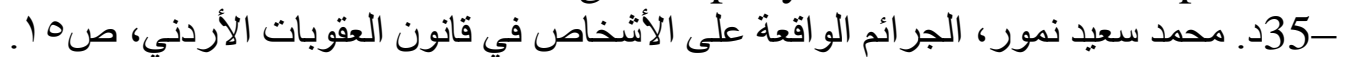

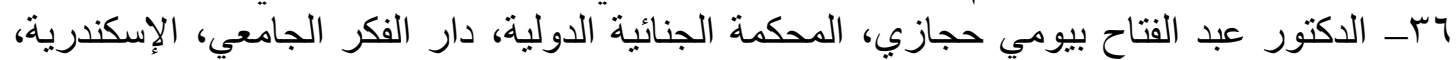

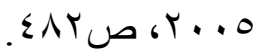

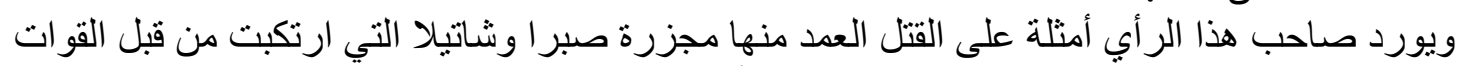

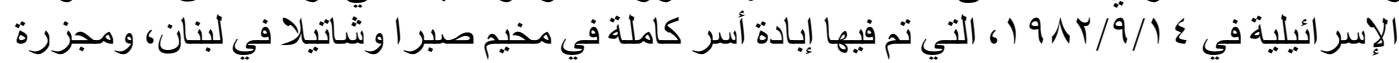

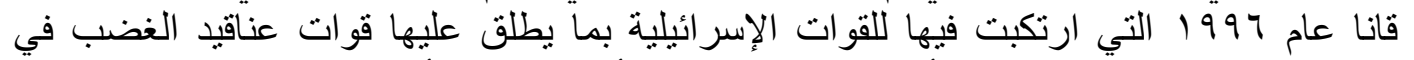

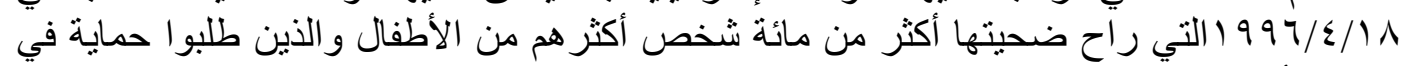

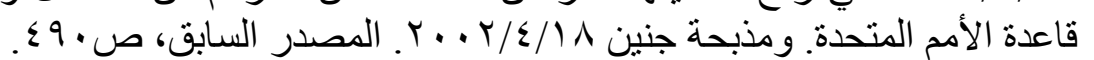
ع ^זــ الدكتور عباس هاثم السعدي، مسؤولية الفرد الجنائية عن الجريمة الدولية، دار المطبوعات

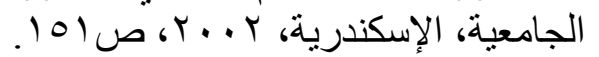

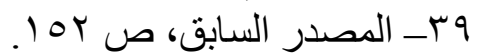

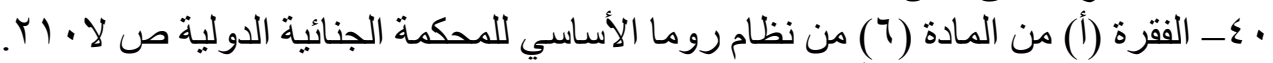
ا (

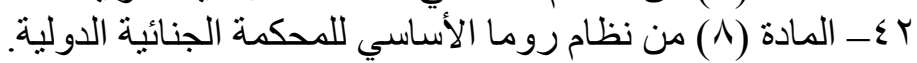

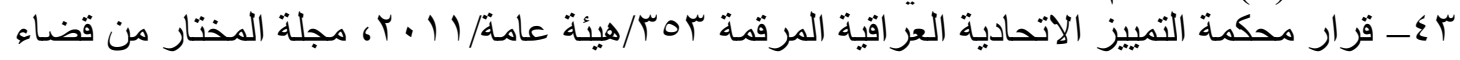

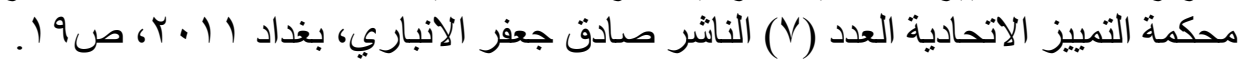

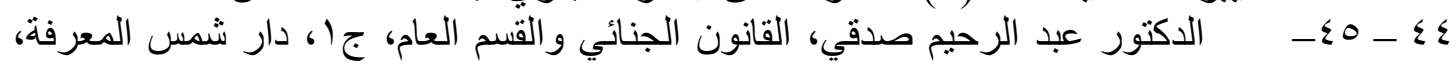

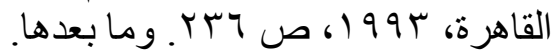

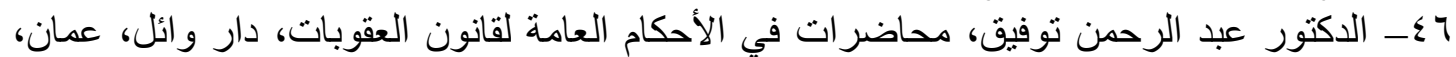

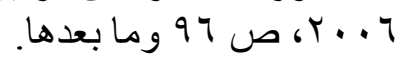

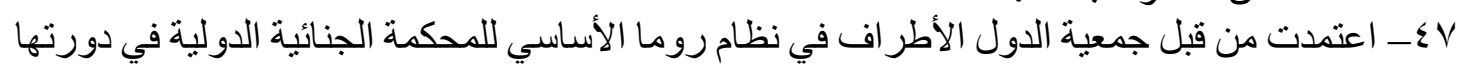

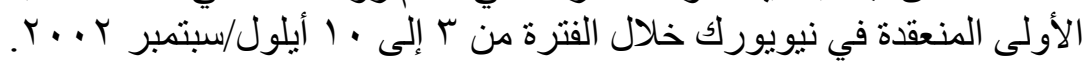
وتر اجع وثثية الأمم المتحدة: وثيقة الأيورة الأمم المتحدة. (ICC - ASP/1/3 SUPP)

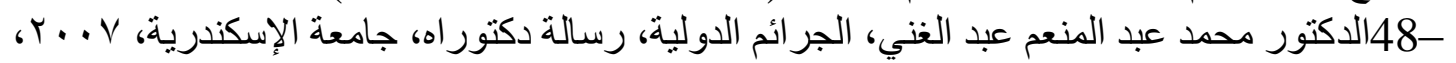

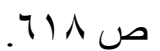

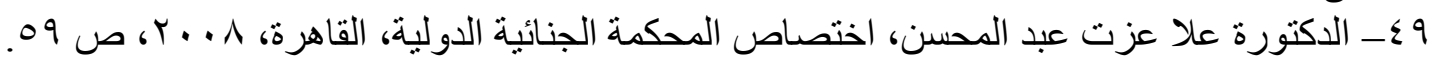

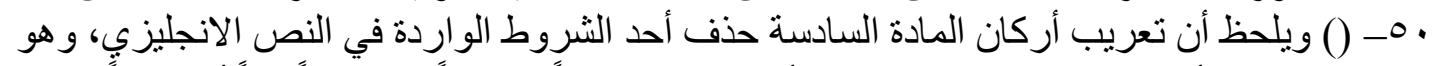
الشرط الخاص بأن يكون القصد فناء الجماعة أو جزء منها هدفاً مخططاً ومدروساً كلياً أو جزئياً: الإني، 